AL $2.1992-64 \mathrm{c} 2$

\title{
Management Plan for Pronghorn Antelope in Alberta
}

Panning Series Nimber 3

is: 8

Alborla FORESTRY LANDS AND WILDLIFE

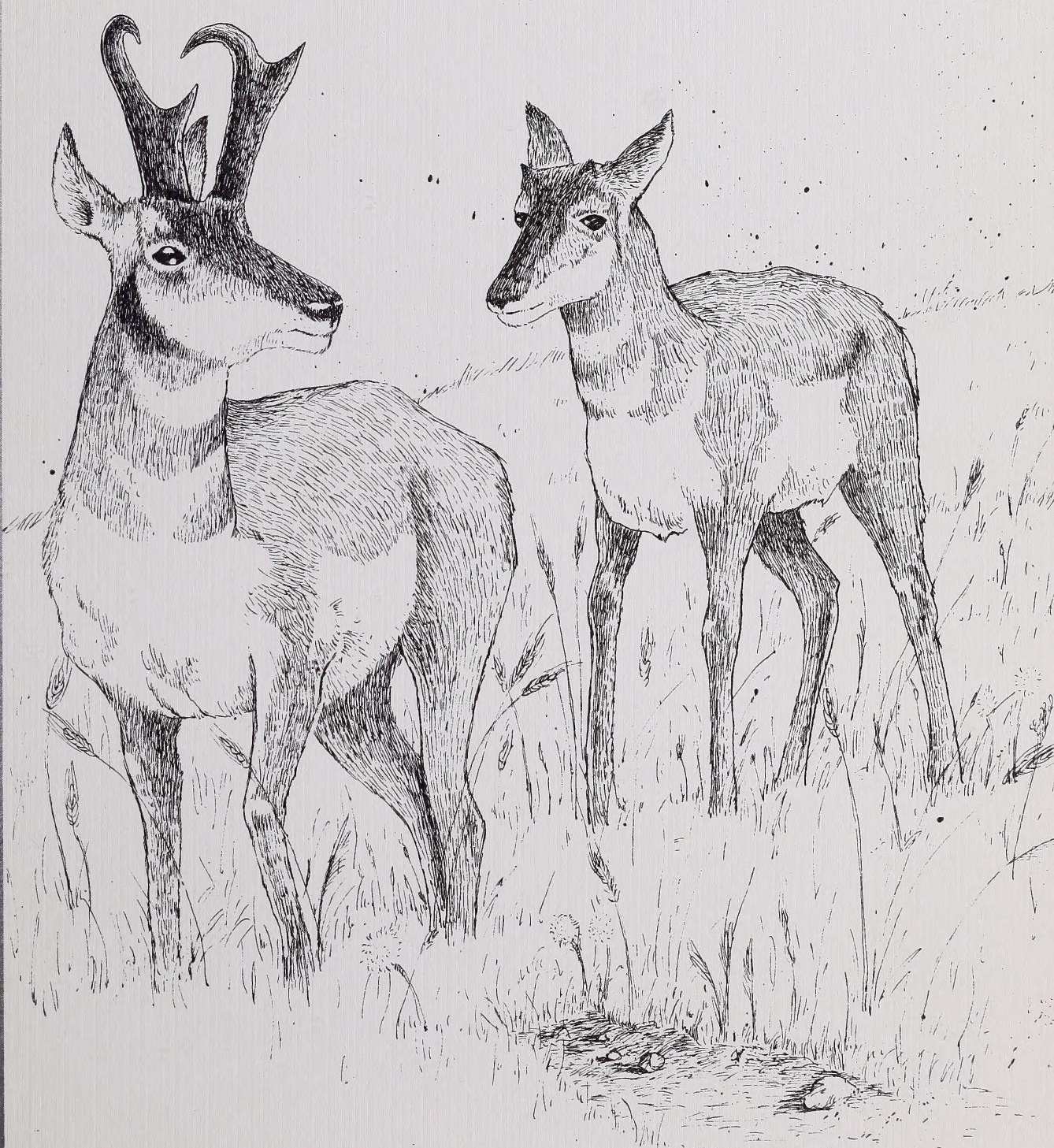


Digitized by the Internet Archive in 2015

https://archive.org/details/managementplanfo00albe_0 
MANAGEMENT PLAN FOR PRONGHORN ANTELOPE

IN ALBERTA

Wildlife Management Planning Series Number 3

November, 1990

Forestry, Lands and Wildlife

Edmonton, Alberta

Fish and Wildlife Division 
Pub. No. $T / 226$

ISBN: $0-86499-733-7$

Copies of this report are available from:

Alberta Forestry, Lands and Wildlife

Fish and Wildlife Division

4th Floor, Bramalea Building

9920 - 108 Street

Edmonton, Alberta

T5K $2 \mathrm{G} 6$

(403) $427-6750$

$O R$

Information Centre

Alberta Forestry, Lands and Wildlife

Main Floor, Bramalea Building

9920 - 108 Street

Edmonton, Alberta

T5K $2 \mathrm{M} 4$

(403) $427-3590$

OR

Information Centre

Alberta Forestry, Lands and Wildlife

Main Floor, Bantrel Building

703 - 6th Avenue S.W.

Calgary, Alberta

T2P OT9

(403) 297-6324 


\section{PREFACE}

The plan presents the Fish and Wildlife Division's goals, objectives and management strategies for the management of pronghorn antelope in Alberta, and will be periodically updated and revised as necessary. Implementation will be subject to Divisional priorities established during the budget process. 



\section{TABLE OF CONTENTS}

PAGE

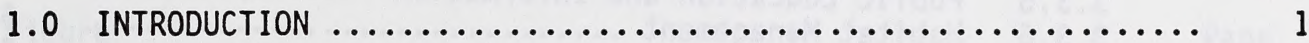

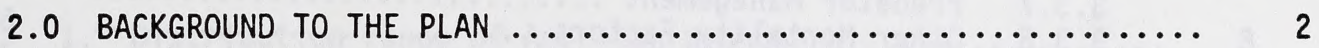

2.1 Taxonomy, Biology and Requirements of Pronghorn

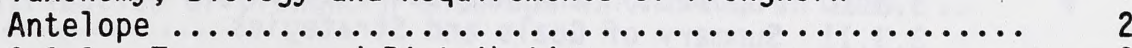

2.1.1 Taxonomy and Distribution ................... 2

2.1.2 General Description ........................ 2

2.1.3 Reproduction .......................... 5

2.1 .4 Mortality ............................ 6

2.1.5 Habitat Requirements and Annual Movements ....... 8

2.2 Historical Status, Use and Management of Pronghorn

Antelope in Alberta ............................. 11

2.2.1 Historical Status of Pronghorn Antelope

2.2.2 Historical Uses and Management of Pronghorn

Antelope in Alberta ..................... 13

2.3 Current Status, Use and Management of Pronghorn Antelope

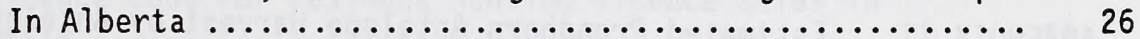

2.3.1 Current Status of Pronghorn Antelope Populations

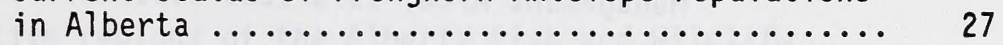

2.3.2 History and Current Status of Pronghorn Antelope Habitat in Alberta ...................... 31

2.3.3 Current Uses of Pronghorn Antelope in Alberta ...

2.3.4 The Value of Pronghorn Antelope to Albertans ....

2.3.5 Current Management Programs for Pronghorn

Antelope in Alberta ..................... 42

2.4 Management Issues and Future Implications ............. 50

2.4.1 Recreational Use ......................... 50

2.4.2 Habitat Retention and Enhancement ............. 51

2.4.3 Population Management .................... 52

2.4.4 Protection of Property $\ldots \ldots \ldots \ldots \ldots \ldots \ldots \ldots . .52$

2.4 .5 The Future $\ldots \ldots \ldots \ldots \ldots \ldots \ldots \ldots \ldots \ldots \ldots \ldots \ldots, 52$

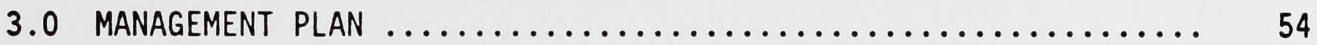

3.1 Policy Framework .............................. 54

3.2 Management Goals and Objectives ..................... 55

3.2.1 Resource Protection ....................... 55

3.2.2 Resource Allocation ........................ 56

3.2.3 Recreational Use ........................... 57

3.2 .4 Commercial Use ............................ 58

3.2 .5 Science and Education ...................... 58 
3.2.6 Protection of Property $\ldots \ldots \ldots \ldots \ldots \ldots \ldots \ldots \ldots, 58$

3.2.7 Population and Habitat ..................... 58

3.3 Management Strategies ......................... 59

3.3.1 Population Management .................... 59

3.3.2 Licencing and Use Management ................ 61

3.3.3 Hunting Seasons .......................... 65

3.3.4 Hunter Effort and Success .................. 65

3.3.5 Public Education and Information .............. 65

3.3.6 Habitat Management ......................... 66

3.3.7 Predator Management ...................... 69

3.3 .8 Other Mortality Factors ................... 69

3.3.9 Protection of Private Property .............. 70

3.3.10 Population and Habitat Inventory .............. 71

3.3.11 Summary of Goals and Strategies ............. 73

4.0 MANAGEMENT PLAN APPLICATION $\ldots \ldots \ldots \ldots \ldots \ldots \ldots \ldots \ldots \ldots \ldots \ldots \ldots \ldots \ldots \ldots$

4.1 Provincial Summary ............................. 75

4.2 Regional Perspective .............................. 75

4.2.1 Southern Region ...................... 75

4.2.2 Central Region ......................... 77

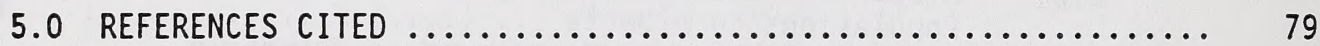

APPENDIX I. Estimated Pronghorn Antelope Populations, 1952-1989. 83

APPENDIX II. Estimated Pronghorn Antelope Harvest by Antelope Management Area, 1973-1989 ................... 86

APPENDIX III. Pronghorn Antelope Buck:Doe:Fawn Ratios by Antelope Management Area, 1963-1989 ................... 95

APPENDIX IV. Provincial Pronghorn Antelope Survey Format ...... 105

APPENDIX V. Ingredient List For Experimental Rations Used in Feeding Trials With Wild Pronghorns ............. 110

APPENDIX VI. Pronghorn Antelope Stable Population Model for Alberta .................................... 112 


\section{List of Figures}

Figure

Page

1. Distribution range of American pronghorn $\ldots \ldots \ldots \ldots \ldots . . .3$

2. Distribution of pronghorn antelope in Alberta in 1989 ... 4

3. Summer pronghorn populations in Alberta, 1952-1989 ..... 14

4. Antelope Hunting Areas from 1964 to $1983 \ldots \ldots \ldots \ldots \ldots .23$

5. Antelope Management Areas from 1984 to present ......... 25

6. Average densities of pronghorns from 1963-1985 by Wildlife Management Unit .............................. 29

7. Known winter ranges for pronghorns in Alberta ......... 33

8. Residence code for resident hunting licence sales in Alberta ................................... 38

9. Administrative regions of the Alberta Fish and Wildlife Division ................................... 76 


\section{List of Tables}

Table

1. Common forage species of pronghorns $\ldots \ldots \ldots \ldots \ldots \ldots \ldots$ 11

2. Availability, number of applicants and numbers of licences issued for trophy and non-trophy antelope, 1963-1989 and antelope archery in 1988 and 1989

3. Annual licence sales, pronghorn harvest and hunter success, 1963-1989

4. History of pronghorn hunting in Alberta, 1907-1989 ..... 19

5. Estimated pronghorn antelope populations and buck:doe:fawn ratios in Alberta in July 1989

6. Comparison between the 1989 buck:doe:fawn ratios and the

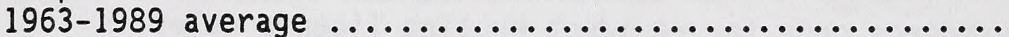

7. Amount of native grass prairie and cultivated land in

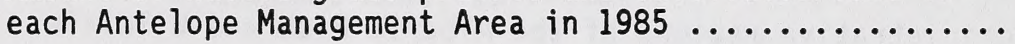

8. Areas of pronghorn winter ranges in Alberta in $1975 \ldots . .34$

9. Pronghorn antelope licence demand, recreation provided

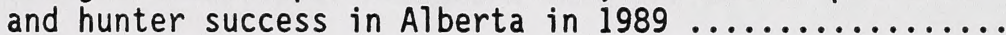

10. Antelope hunter distribution by residence code, 1980-1984

11. Postseason pronghorn antelope population goals in Alberta in 1989

12. Fall preseason and winter pronghorn population goals and

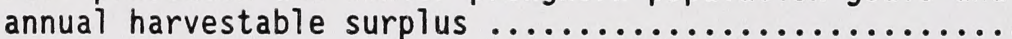

13. Guidelines for the maximum numbers of pronghorn antelope hunters in the field during a hunting season ...........

14. Habitat goals to meet 1999 population goals ............ 


\section{ACKNOWLEDGMENTS}

This plan was prepared by W. M. Glasgow for the Fish and Wildlife Division (R. R. Andrews, Director of Wildlife and B. J. Markham, Head of Planning and Game Management). M. Watson, in a 1986 draft plan, provided significant input for the first draft of this plan. Preliminary drafts were reviewed by R. Bjorge, E. Bruns, D. Culbert, D. Empson, G. Erickson, L. Gudmundson, D. Radford, G. Rowan, L. Russe11, H. Vriend and E. Vuori. Figures were prepared by M. Bradley of Forestry, Lands and Wildlife Cartographic Services. Word processing was done by L. DeBlois, E. Finley, S. Krell, S. Trott and A. Turlione. Editorial Services were provided by $D$. Ealy. 



\section{MANAGEMENT PLAN FOR PRONGHORN ANTELOPE IN ALBERTA EXECUTIVE SUMMARY}

\section{Historical Populations, Use and Management}

Pronghorn antelope in Alberta are at the northern limit of their range and are subject to wide fluctuations in numbers because of climatic extremes such as extended dry periods and severe winters. Pronghorns were still relatively numerous at the beginning of the 20th century but the severe winter of 1906-07 decimated their population. They remained low in number through the next two decades with estimates of fewer than 2000 animals. Numbers increased to an estimated 30000 in 1945 and have fluctuated widely since that time (estimates ranging from 4000 in 1949 after the severe winter of 1948-49 to 32000 in 1984 after several mild winters and moderate harvests). The July 1989 population estimate was 22000 animals.

European settlement of the prairies brought livestock and intensive cultivation (particularly after the advent of irrigation). Thirty-six percent of the total antelope range had been converted from native grass prairie to cultivation by 1983, with 6 of the 36 percent undergoing conversion between 1970 and 1983. On the 12 important winter ranges, 14.4 percent is cultivated with 4.7 percent having been converted between 1950 and 1983. Fences associated with livestock management can impede movements to and from winter ranges. Transportation corridors such as railways and highways may be the sources of significant numbers of collision mortalities in winters of deep snow, when antelope use these snow-free areas.

Antelope were used as a source of food and clothing during the early settlement of Alberta. Today they provide hundreds of thousands of days of recreation for both hunters and nonconsumptive users. Hunting demand has 
been high since populations recovered from extremely low levels in the early 1900s. Licences have been available only on a limited basis since 1957 as demand has outpaced the number of licences available. Currently, about 12000 hunters are vying for about 6000 licences annually, with trophy antelope being the preferred licence. Antelope are also a popular nonconsumptive focus in the prairie habitat types of Alberta.

Management before the 1950 s was limited to changing bag limits, adjusting season lengths, and opening and closing the season. Parks and sanctuaries protected some habitat, but habitat protection efforts were limited. Management now includes population and habitat goals for each of eight Antelope Management Areas, annual inventories of populations, a limited-entry draw to manage the population at goal levels and provide recreation, periodic habitat inventories and a habitat retention program.

\section{Management Issues}

The following four major issues must be addressed in future management programs:

1. Recreational allocation systems must be maintained to manage the herd and optimize public use opportunities while recognizing the concerns of landowners.

2. More effective means of retaining and enhancing habitat in cooperation with other land users on both private and public lands must be developed.

3. Antelope population and habitat inventory must be improved to allow more precise population estimates and clearly defined habitat retention goals.

4. Antelope damage must be minimized by managing the herd at acceptable goal levels, by prevention programs and by exploring compensation alternatives such as range improvement for livestock and antelope. 
These major management issues must be addressed to maintain the antelope populations at goal levels and provide for ongoing public use of the resource.

\section{The Management Plan - Goals/Objectives}

1. The provincial summer antelope population goal will be 18910 with a population of 15500 going into winter. It will be necessary to maintain $25900 \mathrm{~km}^{2}$ of summer range and $3290 \mathrm{~km}^{2}$ of winter range (within the 12 identified winter ranges) to meet these population goals. This does not include the C.F.B. Suffield herd which numbers around 2000 to 4000 in the summer and is outside provincial jurisdiction.

2. A variety of hunting opportunities (archery, trophy, non-trophy) will provide for 4770 Alberta residents to harvest 1670 trophy antelope and 1670 non-trophy antelope annualiy. Limited-entry draws will manage the distribution and number of hunters to provide a quality recreational experience, to manage the resource within each Antelope Management Area and to minimize disturbance to landowners.

3. Nonconsumptive opportunities will be enhanced through the use of print, film and audiovisual material to increase knowledge, and viewing guides and interpretive sites to increase personal contact.

4. Commercial opportunities will be available to those providing outfitting-guiding services. An abundant and widely-distributed antelope population will also help attract tourists to Alberta and produce commercial benefits to those providing goods and services to these tourists.

5. Scientific research and educational activities will be encouraged to enhance our knowledge of antelope and improve management capabilities. 
6. Damage prevention, control and compensation programs will continue. Compensation may be extended to include additional crops, but it is still difficult for insurance adjusters to determine damage. Alternatives such as on-farm habitat improvements that benefit both antelope and livestock will be considered.

7. Habitat retention programs will become more effective through a higher degree of cooperation between wildlife managers and those who manage the land within antelope range (e.g., private landowners, range managers, oil and gas companies, mining and thermal power generating companies, irrigation districts).

8. Habitat and population monitoring programs will become more precise to allow population and habitat retention goals to be focused at more local levels and to better measure success in achieving the identified established goals. 


\subsection{INTRODUCTION}

Pronghorn antelope provided food and clothing items for native Indians and European fur traders and settlers during the early settlement and development of the Alberta prairies. Their major present-day value accrues from the thousands of hours of recreational enjoyment by hunters and nonconsumptive users. Pronghorns also enhance the Alberta economy in the prairie area by stimulating the internal flow of resident dollars into the area and by attracting non-residents to use the resource.

The management of pronghorn antelope in Alberta can be a difficult task. They are at the northern limit of their range in this province and accordingly are susceptible to the extremes of climate. Not only will pronghorn succumb to long cold winters, but they will move great distances to avoid deep snow and to find suitable forage; in Alberta this occasionally means that pronghorns migrate into Saskatchewan or Montana and, in some instances, remain there. In recent times, cultivation and intensive cattle grazing have become a threat to pronghorn habitat.

Recognizing the value of the wildlife resource the Government of Alberta declared a "Fish and Wildlife Policy for Alberta" (Fish and Wildlife Division 1982) in October 1982. Part of that declaration, the "Wildlife Policy," specifically stated that the Government is to ensure that wildlife populations are protected from severe decline and are maintained, and that the wildlife resource is passed on to succeeding generations as it was received. The "Status of the Fish and Wildlife Resource in Alberta" (Fish and Wildlife Division 1984) provided a brief statement of the history, the supply and use of pronghorn antelope in 1980, and a general statement of future direction respecting populations and habitat. The purpose of this species management $p l a n$ is to review the history and current management program for pronghorn antelope in Alberta in more detail and develop comprehensive user, population and habitat goals that will guide pronghorn management over the next 10 years. 


\subsection{BACKGROUND TO THE PLAN}

\subsection{Taxonomy, Biology and Requirements of Pronghorn Antelope}

\subsubsection{Taxonomy and Distribution}

The pronghorn antelope, Antilocapra americana (Ord 1818), is widely distributed in western North America (Figure 1, after Yoakum 1978a). The pronghorn antelope is the only surviving species of the family Antilocapridae, a family indigenous to North America (Yoakum 1978a). There are presently five recognized subspecies and the most abundant subspecies, the American pronghorn (A. a. americana), is the one represented in Alberta. Its distribution in Alberta in 1989 is shown in Figure 2. The terms pronghorn, antelope and pronghorn antelope all refer to Antilocapra americana throughout this document.

\subsubsection{General Description}

The pronghorn antelope is a keen-sighted, gregarious ungulate of the North American plains. The unique feature that has separated pronghorns taxonomically from the bovids is their deciduous keratinized horn sheaths, which are shed annually from ossified cores in response to hormonal cycles.

The pronghorn is the fastest of North American game animals, capable of running at $55 \mathrm{~km} / \mathrm{h}-65 \mathrm{~km} / \mathrm{h}$ with short sprints up to $100 \mathrm{~km} / \mathrm{h}$ (Banfield 1974). The third and fourth digits are developed as cloven hooves, which have a cartilaginous ventral surface to cushion the impact of running hard on irregular surfaces (Kitchen and O'Gara 1982). Pronghorns do not have dew claws and therefore are not as mobile on soft ground or deep snow as other ungulates.

Pronghorns have large eyes ( $5 \mathrm{~cm}$ in diameter), which reportedly are comparable to humans using $8 X$ binoculars (Kitchen 1974). Excellent 


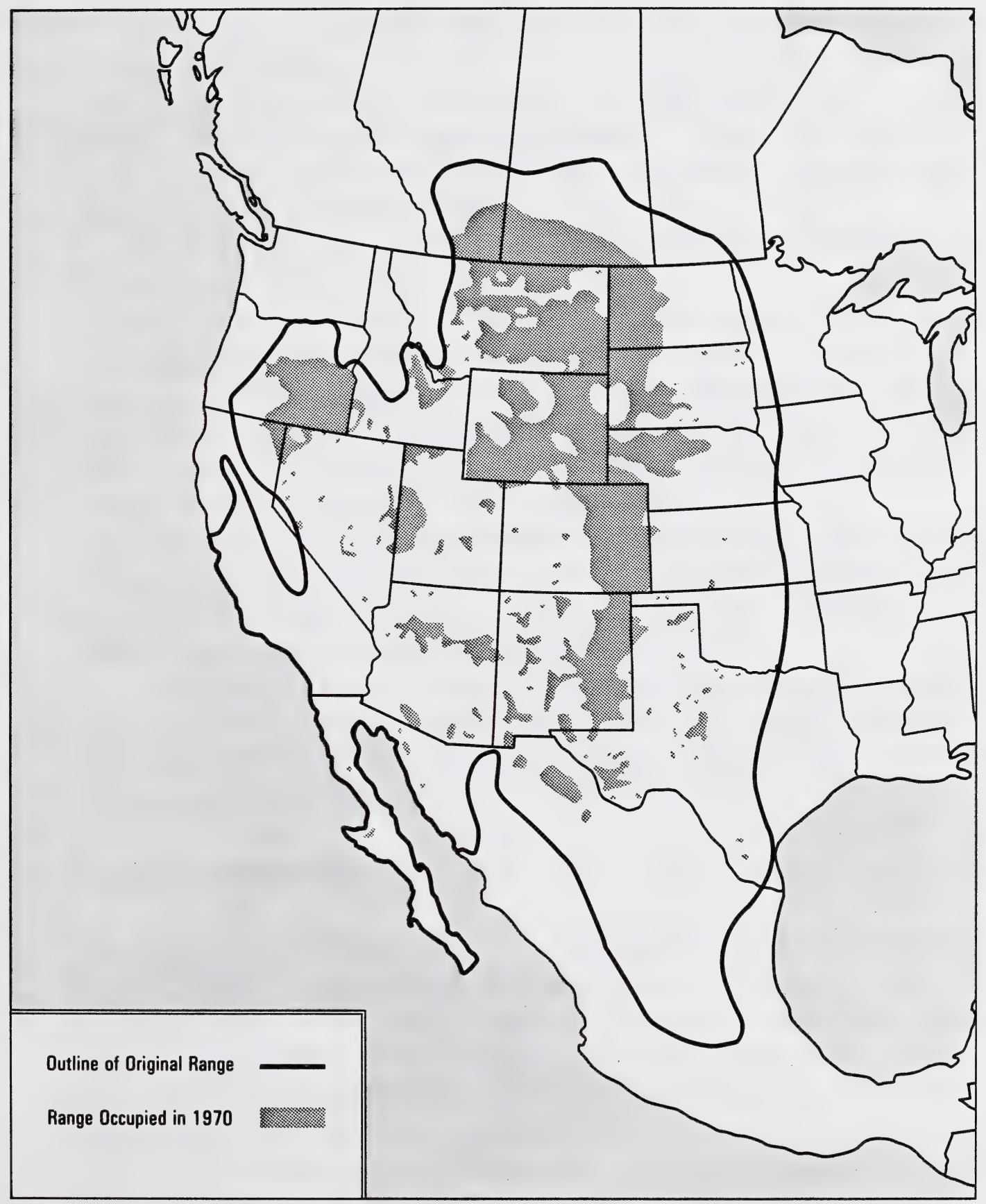

Figure 1. Distribution range of American pronghorn. (Copied from Figure 23, page 112, Schmidt and Gilbert, 1978 with the permission of the Wildlife Management Institute). 


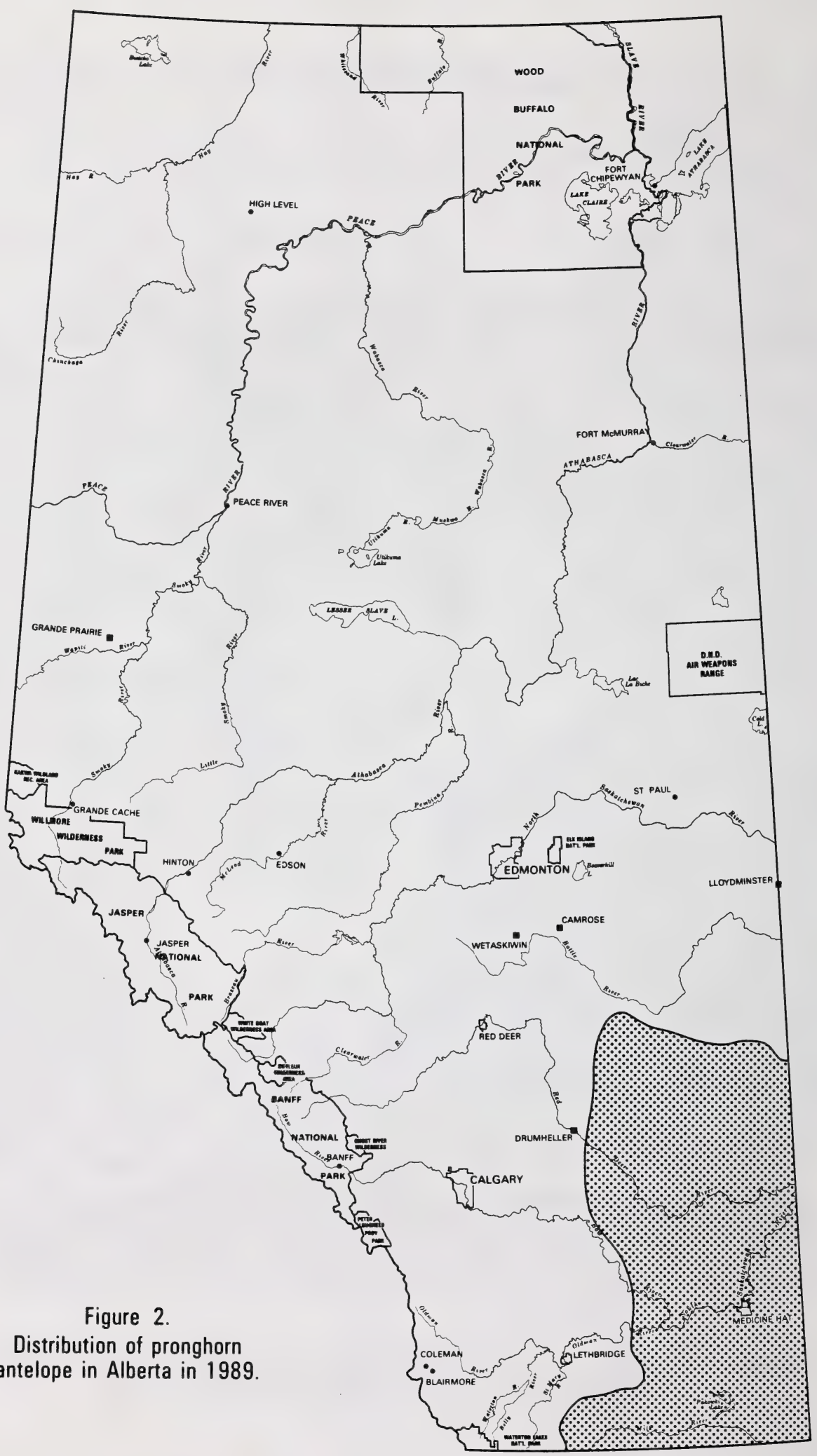


eyesight provides advance notice so pronghorns can avoid predators in the open landscape that they occupy.

Both sexes are reddish brown to tan on the neck, back and legs. Flanks and belly are white. Males have a black cheek patch and often exhibit darker hair over the nose and posteriorly to the base of the horns. Total body length ranges from $125 \mathrm{~cm}-145 \mathrm{~cm}$. In Alberta the mean weight of adult males is $50.5 \mathrm{~kg}$ and the mean weight of adult females is $41.5 \mathrm{~kg}$ (Mitchell 1980).

Females have four mammae. The dental formula for pronghorns is (I $0 / 3 ; C 0 / 1 ; P M 3 / 3 ; M 3 / 3$ ) $\times 2=32$.

Male pronghorns have upright horns, which feature a triangular prong or branch that extends forward from the anterior aspect of each horn and also an upper portion of each horn that typically curves backwards to the tip. Horns on adult males may reach $51 \mathrm{~cm}$. Horns are often absent in females, but where they do occur they are upright, without prongs and generally shorter than the ears.

Both sexes also exhibit a rosette of white erectile hairs on the rump. These hairs can be exposed when the animal is frightened to serve as an alarm signal to other pronghorns. This white rump patch is obvious over great distances on the flat prairie.

Eight dermal glands in the male and six in female pronghorn provide an array of pheromonal signals for territorial marking, courtship displays, alarm signals and other forms of olfactory communication (Kitchen and O'Gara 1982).

\subsubsection{Reproduction}

The rut for antelope occurs in the autumn and lasts two to three weeks. Mitchell (1980) showed that most female pronghorns in Alberta had been bred by the end of September. Mitchell (1980) found that female pronghorns in Alberta were polygravid and that multiple blastocysts developed. However, by November most pregnant females were supporting only two embryos. Females normally attain estrus as yearlings, although yearling females have also been observed to produce young indicating that they were bred as fawns (Wright and Dow 1962).

Territorial behavior in males begins with the return to summer 
range following snow melt and culminates with the rut. Territorial bucks maintain harems of 2-15 does on their territories through dominance displays and herding behavior. This behavior becomes most pronounced during the rut and culminates in the successful breeding of all estrus does.

Barrett (1981) observed that an estimated 75 percent of pregnant does in southern Alberta gave birth between May 23 and 30 . Considering that the peak of the rut is mid-September in Alberta, this indicates a gestation period of approximately 250 days. Pronghorn does usually produce twin fawns, which are about $3 \mathrm{~kg}$ each in weight. The fawns lack some of the dark adult markings and are beige in colour, which camouflages them from predators. They can walk within a half hour of birth and are completely mobile within two days of age.

Gently rolling or hilly terrain provides the preferred fawning sites for pronghorns. The does remain with their fawns for two to three hours after birth, after which they move the fawns to separate bedding sites, which reduce detection by predators. Fawns spend up to 90 percent of their first three weeks bedded some distance from their mothers. The dam returns at regular intervals to feed the fawn or to lead it away from impending danger (Kitchen 1974).

Fawn bedding sites in Alberta were generally in open, rolling or hilly grassland and in association with some micro-geographical feature such as a depression, a stone, a clump of grass, or a wheel rut. A fawn typically oriented itself with its back against some micro-relief, facing downhill if it was bedded on a slope. Areas with good vegetative cover were not selected for fawn bedding sites (Barrett 1981). At about three to four weeks of age the dams and their fawns group together in nursery herds. The fawns associate almost exclusively with the other fawns except during nursing or periods of alarm/flight when the mothers return to their respective fawns. The fawns remain with the dams for 3.5 to 4 months after which they are weaned.

\subsubsection{Mortality}

The average lifespan of a pronghorn is 4.5 years; the oldest documented antelope in Alberta from records of incisor sections was 
11.5 years of age. Important factors in mortality are outlined in the following sections.

\subsubsection{Climate}

Death from exposure and malnutrition, associated with severe winters, is the most significant natural cause of mortality (Mitchell 1980; Barrett 1982). For example, the estimated mortality for pronghorns entering the severe winter of 1977-78 in Alberta was 48.5 percent (Barrett 1982). Barrett (1982) also stated that fawns and adult males died earlier in the winter than did adult females.

\subsubsection{Predation}

Many researchers have found that predation of newborn pronghorns can be an important limiting factor (Beale and Smith 1973; Bodie 1978; Barrett 1978; Von Gunten 1978; Autenrieth 1980; Neff and Woolsey 1980; Showers Corneli et al. 1984). In Alberta, coyotes (Canis latrans) are the major predators of pronghorns, killing about 45 percent of neonates in the first 60 days following parturition. Bobcats take an additional 4.5 percent of fawns for a total predation loss of 50 percent (Barrett 1978, 1982). Golden eagles (Aquila chrysaetos) have also been identified as predators of pronghorn fawns in other jurisdictions (Von Gunten 1978). However, Barrett (1982) suggested that fawn predation losses of up to 50 percent annually have not regulated pronghorn numbers or limited the capacity of the population to grow in Alberta.

\subsubsection{Parasites and Disease}

Outbreaks of viral or bacterial infections seem to be uncommon in pronghorns. Evidence of vibriosis, epizootic hemorrhagic disease, bovine virus diarrhea, parainfluenza 3 , infectious bovine rhinotracheitis, eastern and western encephalomyelitis, leptospirosis and blue tongue have been found in antelope, but no major mortality from these infections has been reported (Autenrieth 1978). During an outbreak of epizootic hemorrhagic disease in Alberta in 1962, 15 dead pronghorns were found (Chalmers et al. 1964). Mitchell (1980) suggested that parasites and disease were relatively unimportant as causative agents of 


\subsubsection{Accidental Death}

Vehicle collisions on highways and railway tracks may cause the deaths of large numbers of antelope, particularly during periods of deep snow when roads and railways are used as feeding or travel corridors (Mitchell 1980). Pronghorns are occasionally hung up in fences or drown in irrigation canals (particularly the new, smooth concrete canals), but the magnitude of this problem is currently unknown.

\subsubsection{Hunting}

The previous four mortality factors can be termed "natural mortality" where there is no intent by people to remove antelope from the population. Hunting involves the sustained removal of an average of 15 to 20 percent of the preseason population. Illegal harvest and crippling loss have yet to be quantified for pronghorns.

\subsubsection{Habitat Requirements and Annual Movements}

The following habitat requirements have been established by consensus of pronghorn managers from all western states and provinces and were summarized in Autenrieth (1978) except where noted by separate citation.

Antelope require low rolling terrain with no major physical barriers such as large rivers, lakes, thick brush or trees and mountain ranges. Gently rolling or hilly terrain is preferred for fawning sites. Antelope habitat should receive $250 \mathrm{~mm}$ - $380 \mathrm{~mm}$ of precipitation annually and snow accumulations should not exceed $25 \mathrm{~cm}-30 \mathrm{~cm}$ for prolonged periods. Because of a light coloured pelage of hollow hair, antelope can readily survive temperature extremes of $-40^{\circ}$ to $+45^{\circ} \mathrm{C}$. At low temperatures, however, wind chill becomes a survival factor particularly for neonates.

Availability of water is important to pronghorns. While some pronghorn populations survive year-round on only the moisture that they extract from succulent forage, most antelope need from $1 L-4 L$ of water per day per animal. Distribution of water sources should 
optimally be no more than $5 \mathrm{~km}-6 \mathrm{~km}$ apart.

Vegetative community composition is equally important to antelope. Areas preferred by pronghorns are characterized by composition of 40 to 60 percent grass, 10 to 30 percent forbs and 5 to 20 percent shrubs. Within these plant communities, species diversity is also important; the preferred norm is 5-10 grass species, 20-40 forb species and 5-10 shrub species as opposed to monotypic vegetative communities (Yoakum 1978b). Barrett (1982) found that during all seasons 85 to 90 percent of pronghorns were found in native grassland/sagebrush habitat; in summer 70 percent of pronghorns used native prairie. In winter more than 40 percent of antelope were found on land containing sagebrush cover. Range with vegetation $38 \mathrm{~cm}$ in average height is preferred by pronghorns; areas with vegetation over $61 \mathrm{~cm}$ is used less frequently and little use is made of areas with vegetation over $76 \mathrm{~cm}$ in height. Barrett (1982) found that vegetative cover in Alberta is not as important a factor in the selection of pronghorn fawn bedding sites as is the topographic relief.

Winter range is a critical prerequisite for the survival of antelope in Alberta. This includes areas that have adequate supplies of sagebrush (Artemesia cana), a winter staple for pronghorns, and exposure to chinook influences or wind scouring to reduce snow depths. Barrett (1974) found that pronghorns preferred areas with more than 10 sagebrush plants per $60 \mathrm{~m}$ of transect. The mean intake of sagebrush per pronghorn was $1.11 \mathrm{~kg}$ per day. Other authors (Bayless 1969; Beale and Smith 1970) suggested that browse, predominantly sagebrush, forms more than 90 percent of the winter diet of pronghorns in northern ranges. Mitchell (1980) showed from antelope rumen analysis that pronghorns in southern Alberta consumed 54 percent browse during the winter months. Two Artemesia species, sagebrush and pasture sagewort (A. frigida) constituted 69 percent of the diet during that period. Other shrub species that can be important to the winter survival of pronghorns as shelter during periods of deep snow and cold temperature are trembling aspen (Populus tremuloides), willow (Salix spp.), silverberry (Elaeagnus commutata) and snowberry (Symphoricarpos occidentalis) (Barrett 1982; Mitchell and Smoliak 1971).

Common preferred food species of pronghorns in Alberta are included 
in Table 1. Mitchell and Smoliak (1971) identified 52 forbs, 12 browse species and an undetermined number of grasses and sedges in rumen samples of Alberta pronghorns.

Soils do not appear to be a limiting factor to pronghorns except on a very localized basis. The saturated soils of slough bottoms, irrigation ditches and intermittent stream beds and lake beds, and the associated grass and forb communities can provide important summer range particularly in years of poor precipitation (Good and Crawford 1978).

Migratory behavior is characteristic of antelope on northern ranges. Pronghorns typically move to wintering areas that represent about 8 percent of the summer range in Alberta (Barrett 1982). Barrett (1982) found that 66 percent of the pronghorns that were observed on normal winter ranges in Alberta during January and early February of 1978 (a severe winter) had moved away from these winter ranges by March to locations where snow depths were reduced. Man-made obstacles can have a significant impact on pronghorns, particularly where winter survival depends on the animals' ability to migrate to areas where forage is more easily obtained. Oakley (1973) identified the problems associated with livestock fences, which impede movement on antelope ranges. As well, pronghorns are sensitive to the presence of roadways or railways, especially where the vehicular activity is irregular (Autenreith 1978). Mitchell (1980) documented the significant mortality of pronghorns due to vehicular and train collisions during the severe winter of 1964. Many animals were killed or injured as they sought the snow-free areas along raised road and rail beds.

\subsection{Historical Status, Use and Management of Pronghorn Antelope in} Alberta

This section provides a brief overview of the historical status of pronghorn antelope populations and how people used these populations. It also outlines the evolution of pronghorn management programs leading up to the present management program outlined in Section 2.3 of this document. 
Table 1. Common forage speciesa of pronghorns (Mitchell 1980; Mitchell and Smoliak 1971).

\begin{tabular}{|c|c|c|}
\hline & Common Name & Scientific Name \\
\hline Shrubs & $\begin{array}{l}\text { sagebrush } \\
\text { snowberry } \\
\text { silverberry } \\
\text { willows } \\
\text { creeping juniper }\end{array}$ & $\begin{array}{l}\frac{\text { Artemesia cana }}{\text { Symphoricarpos }} \text { occidental is } \\
\text { Elaeagnus commutata } \\
\text { Salix spp. } \\
\text { Juniperus horizontalis }\end{array}$ \\
\hline Forbs & $\begin{array}{l}\text { pasture sagewort } \\
\text { cushion cactus } \\
\text { yellow sweet clover } \\
\text { wild tomato } \\
\text { yellow goat's-beard } \\
\text { common knotweed } \\
\text { fairy candelabra } \\
\text { scarlet butterfly-weed } \\
\text { Colorado rubber-plant } \\
\text { prickly-pear } \\
\text { moss phlox } \\
\text { golden aster } \\
\text { broomweed } \\
\text { spiny ironplant } \\
\text { alpine hedysarum } \\
\text { everlasting } \\
\text { graceful cinquefoil } \\
\text { lance-leaved pyrrocoma } \\
\text { thistles }\end{array}$ & $\begin{array}{l}\text { Artemesia frigida } \\
\text { Coryphantha vivipara } \\
\text { Melilotus officinalis } \\
\text { Solanum triflorum } \\
\text { Tragopogon } \frac{\text { dubius }}{\text { Polygonum arenastrum }} \\
\text { Androsace septentrionolis } \\
\text { Gaura coccinea } \\
\text { Hymenoxys richardsonii } \\
\text { Opuntia polyacantha } \\
\text { Phlox hoodii } \\
\text { Heterotheca } \\
\text { Gutierrezia } \\
\text { Happlopappus sarothrae } \\
\text { Hedysarum alpinum } \\
\text { Antennaria sp. } \\
\text { Potentilla gracilis } \\
\text { Happlopappus lanceolatus } \\
\text { Cirsium spp. }\end{array}$ \\
\hline Grasses & $\begin{array}{l}\text { common wheat } \\
\text { sedges } \\
\text { needle and thread } \\
\text { blue grama } \\
\text { June grass } \\
\text { western wheat grass } \\
\text { Sandberg bluegrass }\end{array}$ & $\begin{array}{l}\text { Triticum aestivum } \\
\text { Carex spp. } \\
\text { Stipa comata } \\
\text { Bouteloua gracilis } \\
\text { Koeleria macrantha } \\
\text { Agropyron smithii } \\
\text { Poa sandbergii }\end{array}$ \\
\hline
\end{tabular}

aspecies nomenclature brought up-to-date (Moss 1983). 
Early explorers reported pronghorns from the Red River in Manitoba to the foothills of the Rocky Mountains (Mitchell 1980). When Lewis and Clark first ventured across the North American prairies in 1804 they observed vast herds of pronghorn antelope (Tsukamoto 1983). Pronghorns were still relatively numerous in Alberta at the beginning of the 20th century, but the severe winter of 1906-07 greatly reduced antelope numbers and eliminated them from much of their former range (Mitchell 1980). In an attempt to establish protected herds of pronghorn for future relocations the Alberta government authorized the capture of wild pronghorns for Banff National Park and the Wainwright Buffalo Park in 1909 and 1910 (OC 358/09; OC 264/10).

Human settlement and illegal shooting caused further reductions in pronghorn numbers until 1913 when hunting of pronghorns was prohibited. This prohibition remained in effect until 1935 (Mitchell 1980). In 1914 the Wawaskesey National Park was established and in the following year the Nemiskam National Park was founded. The purpose of both of these parks was to provide refugia specifically for pronghorns (Lothian 1977). The Alberta government also passed legislation which permitted C. J. Blazier to establish an antelope farm near Lake Newell in 1920. Young pronghorn from Blazier's farm were relocated in Alberta and the United States to replenish wild herds (Mitchell 1980).

An extensive continental pronghorn survey in the early 1920s indicated fewer than 2000 animals in Alberta. A series of mild winters from 1929 to 1934 permitted pronghorn populations to expand at exponential rates and in spite of the dry summers and severe winters of the late thirties, antelope were estimated to number about 30000 animals in Alberta by 1945 (Wishart 1972). The winter of 1948/49 was characterized by cold temperatures and deep snow accumulations. Pronghorn mortality was extreme and the provincial population estimate plummeted to around 4000 animals. Following the $1949 \mathrm{crash}$, pronghorn numbers generally increased until 1956. A series of declines and increases was observed in the antelope population following the 1956 levels, until 1964 when the population peaked at 21000 animals (Mitchell 1980). 
The severe winters in 1965, 1966 and 1967 again resulted in high pronghorn mortality and emigration, and poor fawn production. By 1967 there were only about 8500 animals in Alberta. The hunting season was closed in 1969 and when it opened in 1970, a new "trophy" law was in place whereby only male antelope with horns $12.6 \mathrm{~cm}$ or more in length could be hunted. A hunting season for females and fawns (non-trophy) was established in 1977 but was closed again in 1978 and 1979. A nontrophy antelope hunting season was reopened in 1980 when the provincial population reached 18500 animals; this hunting season has occurred on an annual basis since. Limited entry hunting seasons and low winter mortality resulted in a dramatic increase in the antelope population. By 1984 there were an estimated 32000 pronghorns in Alberta. The provincial antelope survey in July 1989 estimated 22314 animals. Population estimates from 1952 to 1989 are presented in Figure 3; regional and provincial estimates are included in Table $A$ of Appendix I.

\subsubsection{Historical Uses and Management of Pronghorn Antelope in Alberta}

\subsubsection{User Demand and Harvest}

Table 2 summarizes the demand for licences (Number of Applicants), the number of licences recommended (or available) to achieve the harvest goal, and the number of licences actually issued for both trophy and non-trophy antelope from 1963-1989 and archery antelope in 1988 and 1989. The period of ineligibility for application for a licence is also indicated because this makes the demand appear lower than it actually would be if hunters could apply every year. The hunter success rates and estimated harvests appear in Table 3. Although the number of animals harvested has varied widely over the years, the hunter success rates have remained very constant. Harvest data by Antelope Management Area (i.e., hunting area) from 1973 to 1989 are presented in Tables $A-H$ in Appendix II.

\subsubsection{Licencing, Bag Limits and Hunting Seasons}

Antelope management efforts in Alberta have increased since 1949 when an unlimited number of licences were issued for the $4025 \mathrm{~km}^{2}$ of antelope range that was open to hunting. This occurred at a time when 


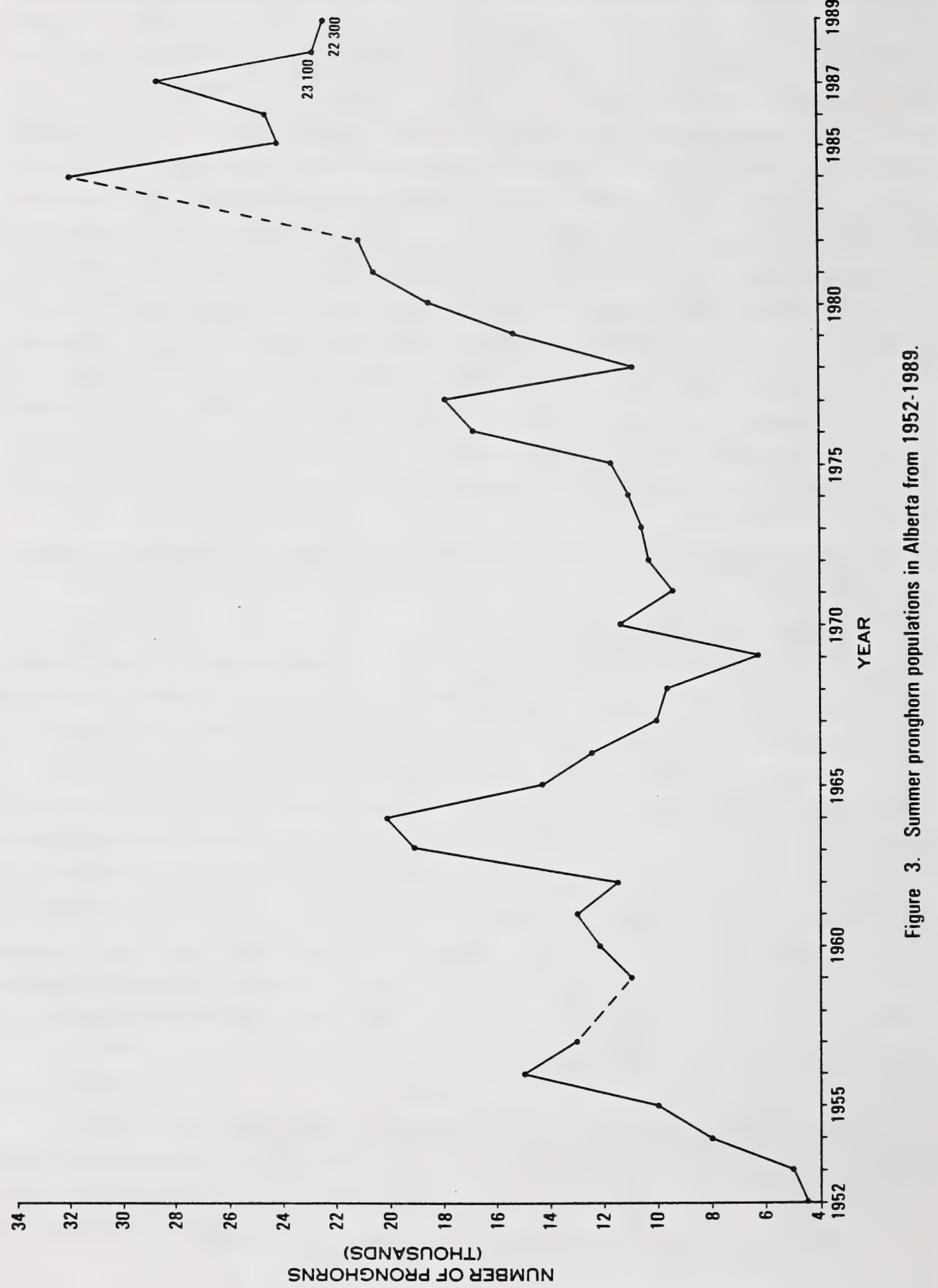




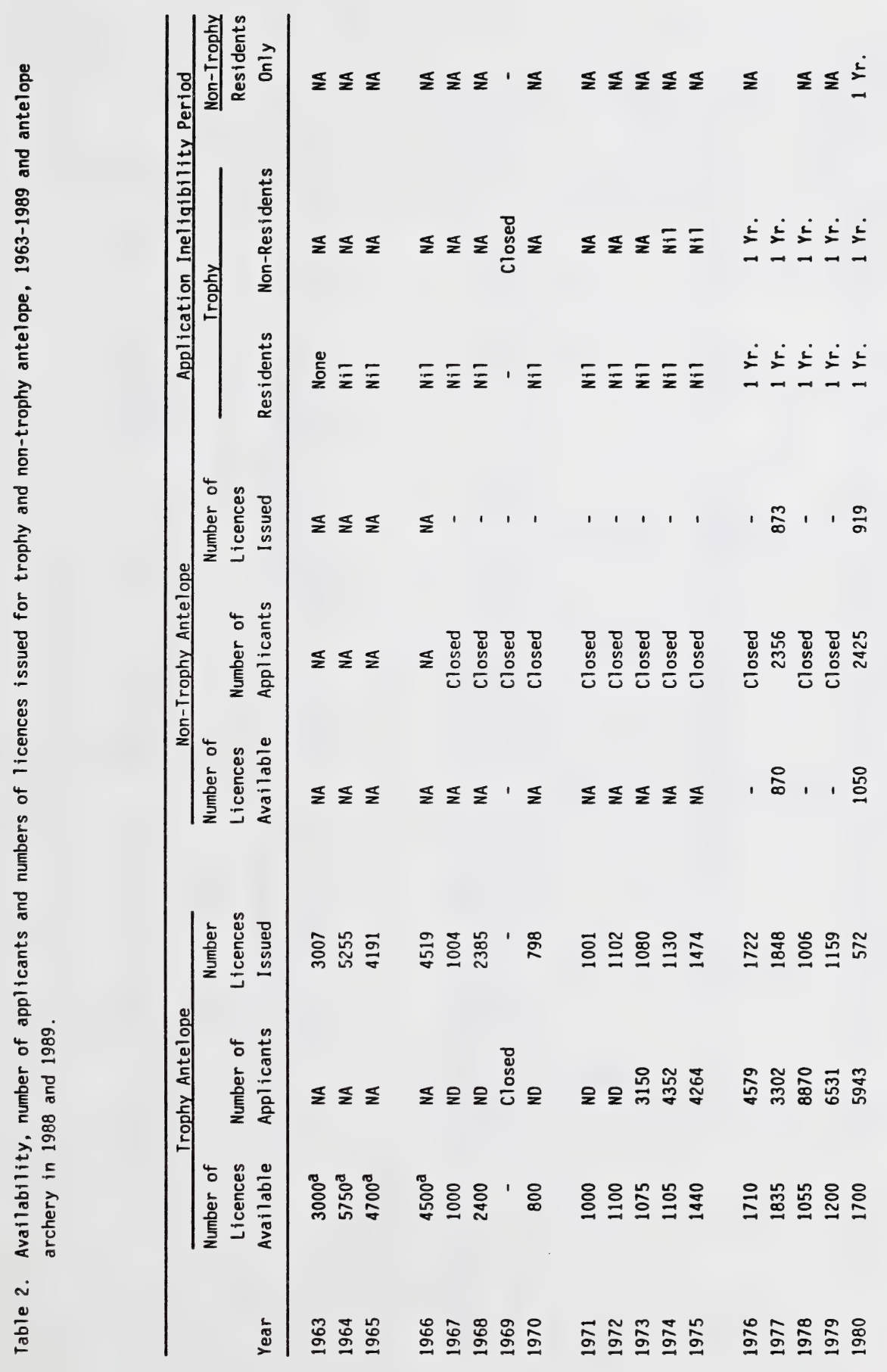




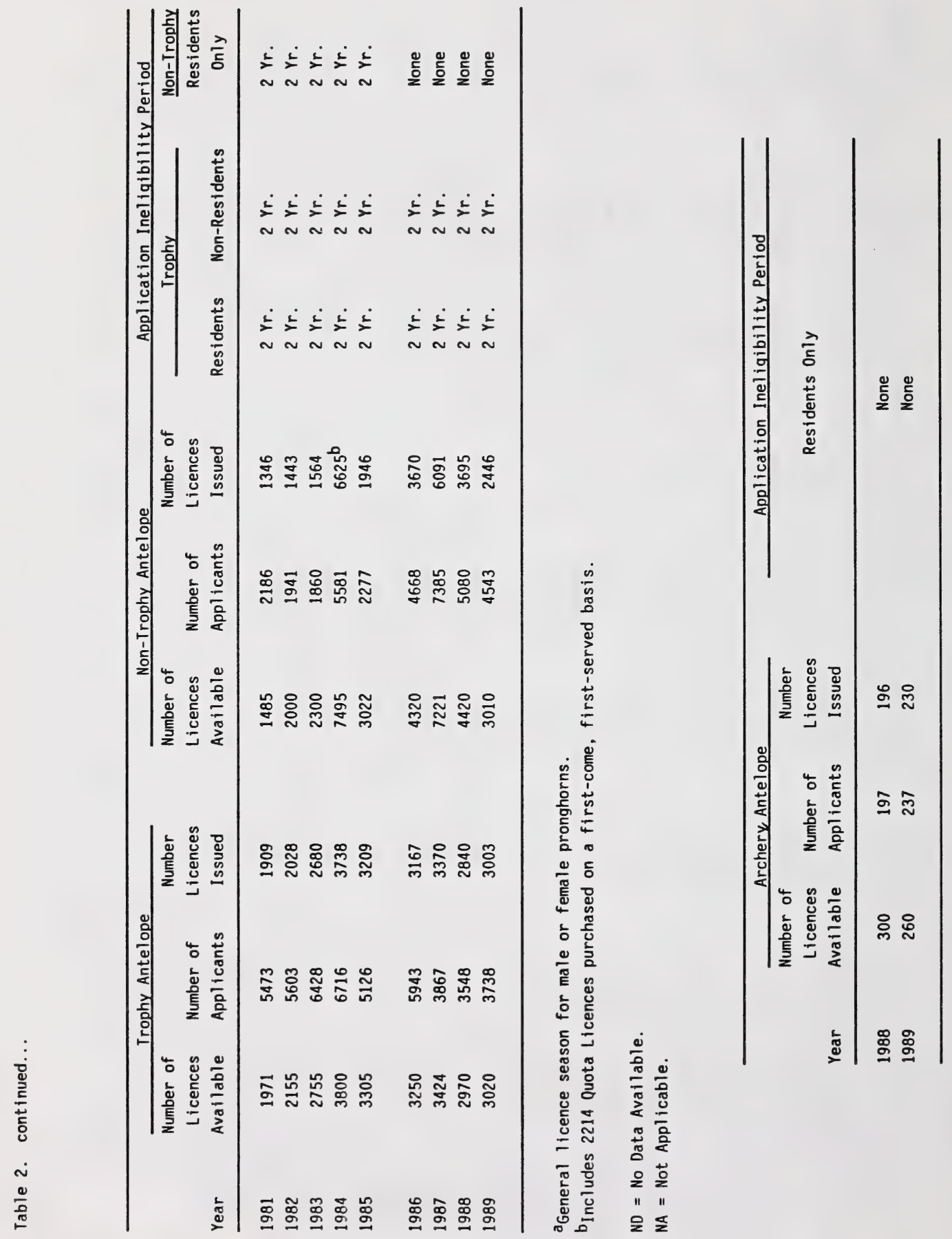


Table 3. Annual licence sales, pronghorn harvest and hunter success, 1963-1989.

\begin{tabular}{|c|c|c|c|c|c|}
\hline Year & $\begin{array}{l}\text { Number } \\
\text { Licences } \\
\text { Sold }\end{array}$ & $\begin{array}{l}\text { Estimated } \\
\text { Number } \\
\text { Active } \\
\text { Hunters }\end{array}$ & $\begin{array}{l}\text { Estimated } \\
\text { Number } \\
\text { Antelope } \\
\text { Harvested }\end{array}$ & $\begin{array}{l}\text { Hunter Success } \\
\text { Based on } \\
\text { Number } \\
\text { Licences } \\
\text { Sold }\end{array}$ & $\begin{array}{l}\text { Rates (\%) } \\
\text { Based on } \\
\text { Number } \\
\text { Active } \\
\text { Hunters }\end{array}$ \\
\hline $\begin{array}{l}1963 \\
1964 \\
1965\end{array}$ & $\begin{array}{ll}3 & 007 \\
5 & 255 \\
4 & 191\end{array}$ & $\begin{array}{ll}2 & 791 \\
5 & 068 \\
3 & 866\end{array}$ & $\begin{array}{ll}2 & 422 \\
4 & 308 \\
3 & 170\end{array}$ & $\begin{array}{l}81 \\
82 \\
76\end{array}$ & $\begin{array}{l}87 \\
85 \\
82\end{array}$ \\
\hline $\begin{array}{l}1966 \\
1967 \\
1968 \\
1969 \\
1970\end{array}$ & $\begin{array}{r}4519 \\
1004 \\
2385 \\
\text { Closed } \\
798\end{array}$ & $\begin{array}{r}4420 \\
\text { No Data } \\
\text { No Data } \\
\overline{730}\end{array}$ & $\begin{array}{c}3478 \\
496 \\
955 \\
- \\
481\end{array}$ & $\begin{array}{l}77 \\
49 \\
40 \\
- \\
60\end{array}$ & $\begin{array}{l}79 \\
- \\
- \\
66\end{array}$ \\
\hline $\begin{array}{l}1971 \\
1972 \\
1973 \\
1974 \\
1975\end{array}$ & $\begin{array}{ll}1 & 001 \\
1 & 102 \\
1 & 080 \\
1 & 130 \\
1 & 474\end{array}$ & $\begin{array}{ll} & 930 \\
1 & 004 \\
1 & 044 \\
1 & 048 \\
1 & 398\end{array}$ & $\begin{array}{r}628 \\
665 \\
798 \\
739 \\
1122\end{array}$ & $\begin{array}{l}63 \\
60 \\
74 \\
65 \\
76\end{array}$ & $\begin{array}{l}68 \\
66 \\
76 \\
71 \\
80\end{array}$ \\
\hline $\begin{array}{l}1976 \\
1977 \\
1978 \\
1979 \\
1980\end{array}$ & $\begin{array}{ll}1 & 722 \\
2 & 721 \\
1 & 006 \\
1 & 159 \\
2 & 491\end{array}$ & $\begin{array}{ll}1 & 618 \\
2 & 449 \\
& 926 \\
1 & 078 \\
2 & 303\end{array}$ & $\begin{array}{rl}1 & 260 \\
1 & 995 \\
& 674 \\
& 914 \\
1 & 935\end{array}$ & $\begin{array}{l}78 \\
73 \\
67 \\
79 \\
78\end{array}$ & $\begin{array}{l}78 \\
81 \\
73 \\
85 \\
84\end{array}$ \\
\hline $\begin{array}{l}1981 \\
1982 \\
1983 \\
1984 \\
1985 \\
1986 \\
1987 \\
1988 \\
1989\end{array}$ & $\begin{array}{rr}3 & 255 \\
3 & 471 \\
4 & 244 \\
10 & 363 \\
5 & 155 \\
6 & 837 \\
9 & 461 \\
6 & 535 \\
5 & 449\end{array}$ & $\begin{array}{ll}2 & 815 \\
3 & 089 \\
3 & 774 \\
9 & 100 \\
4 & 728 \\
5 & 969 \\
8 & 941 \\
5 & 508 \\
4 & 769\end{array}$ & $\begin{array}{ll}2 & 364 \\
2 & 640 \\
3 & 309 \\
6 & 757 \\
3 & 950 \\
4 & 694 \\
7 & 783 \\
4 & 433 \\
4 & 011\end{array}$ & $\begin{array}{l}73 \\
76 \\
78 \\
65 \\
59 \\
69 \\
82 \\
68 \\
74\end{array}$ & $\begin{array}{l}84 \\
85 \\
88 \\
74 \\
84 \\
79 \\
87 \\
80 \\
84\end{array}$ \\
\hline TOTAL & 90815 & 79366 & 65992 & 73 & 81 \\
\hline
\end{tabular}


antelope had already suffered severe winter mortality. A six-year closure of the season was the result of this overharvest (Wishart 1972).

In 1957, a limited number of pronghorn licences was issued on a first-come, first-served basis. In 1964 the Eastern Irrigation District, which had been closed to hunting for the previous three years, was reopened to hunting and licences were issued through a limited entry draw for the seven Antelope Hunting Areas. This practice of selecting a limited number of hunters per hunting area has continued since 1964. Table 4 presents a detailed outline of pronghorn hunting bag limits and seasons from 1907 to 1989.

Pronghorn hunting in Alberta was open to residents only, from 1907 to 1935 ; licence fees were $\$ 5.00$. From 1936 to 1949 , non-residents were allowed to hunt as we11. Resident fees ranged from $\$ 3.00$ to $\$ 6.00$ during the latter period, while non-residents paid from $\$ 12.50$ to $\$ 50.00$. From 1956 until 1974 only residents could hunt antelope. Fees were $\$ 5.00$, increasing to $\$ 7.50$ in 1966 and $\$ 10.00$ in 1970 .

In 1967, a priority selection system was initiated for resident antelope hunters. A colored card was returned with all unsuccessful applications. These cards were to be submitted in 1968 with the application forms for antelope licences, so those applicants could be given selection priority. However, there were problems with hunters retaining their cards until the 1968 hunting season, and following the 1969 antelope season closure, the system was dropped. Non-residents were again allowed to hunt trophy antelope from 1975 to 1979. Fees were $\$ 10.00$ for residents and $\$ 25.00$ for non-residents. A regulation amendment was also passed in 1975 which applied to the 1976 hunting season. Anyone holding a trophy antelope licence in any year was ineligible to apply for a trophy antelope licence the following year.

In 1980, a non-trophy antelope (any antelope with horns $7.6 \mathrm{~cm}$ or less in length) season was established for residents with a licence fee of $\$ 10.00$. The resident trophy antelope licence was raised to $\$ 20.00$ and the non-resident trophy antelope licence fee was increased to $\$ 125.00$.

In 1981, a two-year wait-out period before re-application for any antelope licence was applied to anyone holding either a trophy or non-trophy antelope licence. This change was motivated by demand for 
Table 4. History of pronghorn hunting in Alberta, 1907-1989.

\begin{tabular}{|c|c|c|c|c|}
\hline Yeara & Season Dates & Season Type & $\begin{array}{l}\text { Season Duration } \\
\text { (Days) }\end{array}$ & Bag Limit \\
\hline $1907-1912$ & & General & 3 & \\
\hline 1913 & Oct. 1 - Nov. 1 & General & 28 & \\
\hline $1914-1933$ & Closed & - & & \\
\hline 1934 & No Season & & & \\
\hline 1935 & $\begin{array}{l}\text { Nov. } 1-11 \\
\text { Dec. } 2-10 \\
\text { Jan. } 1-12\end{array}$ & $\begin{array}{c}\text { General } \\
\text { " }\end{array}$ & $\begin{array}{r}9 \\
8 \\
10\end{array}$ & $\begin{array}{l}\text { 2-Either Sex } \\
\text { 1-Male Only } \\
\text { 1-Male Only }\end{array}$ \\
\hline 1936 & Oct. 5-21 & $"$ & 15 & 2-Either Sex \\
\hline 1937 & Oct. 5-21 & $"$ & 15 & 2-1 Must Be Male \\
\hline 1938 & Oct. $10-29$ & $"$ & 18 & 1-Either Sex \\
\hline 1939 & Closed & & & \\
\hline 1940 & $\begin{array}{l}\text { Oct. } 15-30 \\
\text { (Eastern } \\
\text { Irrigation Dist. } \\
\text {-EID-Closed) }\end{array}$ & General & 14 & 1-Either Sex \\
\hline 1941 & Oct. 20-Nov. 1 & General & 12 & 2-Either Sex \\
\hline 1942 & Oct. 15-31 & $"$ & 14 & 1-Male \\
\hline & Nov. 4-14 & $"$ & 10 & 2-Males \\
\hline 1943 & 0ct. $18-30$ & $"$ & 12 & 1-Either Sex \\
\hline 1944 & Oct. 23-Nov. 11 & " & 18 & 1-Either Sex \\
\hline 1945 & Oct. 22-Nov. 10 & " & 18 & 1-Either Sex \\
\hline 1946 & Oct. 21-Nov. 9 & $"$ & 18 & 1-Either Sex \\
\hline 1947 & Closed & & & \\
\hline 1948 & Oct. 25-Nov. 6 & General & 12 & 1-Either Sex \\
\hline 1949 & Oct. 24-Nov. 5 & $"$ & 12 & 1-Either Sex \\
\hline 1950-1955 & Closed & & & \\
\hline 1956 & Nov. 23-30 & General & 6 & 1-Either Sex \\
\hline 1957 & Nov. 1-9 & Limited General Lic. & 8 & 1-Either Sex \\
\hline 1958 & Nov. $1-8$ & Limited Entry Draw (LED) & 7 & 1-Either Sex \\
\hline 1959 & Closed & & & \\
\hline
\end{tabular}

(continued) 


\begin{tabular}{|c|c|c|c|c|}
\hline Yeara & Season Dates & Season Type & $\begin{array}{c}\text { Season Duration } \\
\text { (Days) }\end{array}$ & Bag Limit \\
\hline 1960 & Nov. $7-12$ & LED & 6 & 1-Either Sex \\
\hline 1961 & Nov. 6-11 & $"$ & 6 & 1-Either Sex \\
\hline 1962 & Nov. $10-17$ & $"$ & 7 & 1-Either Sex \\
\hline 1963 & Oct. 25 -Nov. 2 & $"$ & 7 & 1-Either Sex \\
\hline 1964 & $\begin{array}{l}\text { Oct. 24-31 } \\
\text { (EID Opened) }\end{array}$ & LED - 7 Areas & 7 & $\begin{array}{l}\text { 1-Either Sex } \\
\text { E.I.D. Opened }\end{array}$ \\
\hline 1965 & 0ct. $23-30$ & $"$ & 7 & 1-Either Sex \\
\hline 1966 & 0ct. $22-29$ & $"$ & 7 & 1-Either Sex \\
\hline 1967 & Oct. $21-28$ & $"$ & 7 & 1-Male Only \\
\hline $1968^{a}$ & 0ct. 22-29 & $"$ & 7 & 1-Male Only \\
\hline 1969 & Closed & & & \\
\hline 1970 & Oct. 24-31 & $"$ & 7 & 1-Trophy \\
\hline 1971 & 0ct. $25-30$ & $"$ & 6 & 1-Trophy \\
\hline 1972 & Oct. $23-28$ & $"$ & 6 & 1-Trophy \\
\hline 1973 & Oct. $22-27$ & $"$ & 6 & 1-Trophy \\
\hline 1974 & Oct. 21-26 & $"$ & 6 & 1-Trophy \\
\hline 1975 & 0ct. $20-25$ & $"$ & 6 & 1-Trophy \\
\hline 1976 & Oct. $25-30$ & $"$ & 6 & 1-Trophy \\
\hline \multirow[t]{2}{*}{1977} & Oct. $17-22$ & $"$ & 6 & 1-Trophy \\
\hline & Oct. $20-22$ & $"$ & 3 & 1-Non-Trophy \\
\hline 1978 & Oct. 23-28 & " & 6 & 1-Trophy \\
\hline 1979 & Oct. $22-27$ & $"$ & 6 & 1-Trophy \\
\hline \multirow[t]{2}{*}{1980} & Oct. 27-Nov. 1 & $"$ & 6 & 1-Trophy \\
\hline & Oct. 30 -Nov. 1 & $"$ & 3 & 1-Non-Trophy \\
\hline \multirow[t]{2}{*}{1981} & Oct. 26-31 & $"$ & 6 & 1-Trophy \\
\hline & Oct. 29-31 & $"$ & 3 & 1-Non-Trophy \\
\hline \multirow[t]{2}{*}{1982} & 0ct. $25-30$ & $"$ & 6 & 1-Trophy \\
\hline & Oct. $28-30$ & " & 3 & 1-Non-Trophy \\
\hline \multirow[t]{3}{*}{1983} & Oct. 24-29 & $"$ & 6 & 1-Trophy \\
\hline & Oct. 27-29 & " & 3 & 1-Non-Trophy \\
\hline & & & & (continued) \\
\hline
\end{tabular}




\begin{tabular}{|c|c|c|c|c|}
\hline Yeara & Season Dates & Season Type & $\begin{array}{c}\text { Season Duration } \\
\text { (Days) }\end{array}$ & Bag Limit \\
\hline \multirow[t]{3}{*}{1984} & Oct. $22-27$ & LED - 8 Areas & 6 & 1-Trophy \\
\hline & Oct. 25-27 & 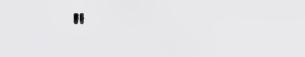 & 3 & 1-Non-Trophy \\
\hline & Oct. $29-31$ & $"$ & 3 & 1-Non-Trophy \\
\hline \multirow[t]{3}{*}{1985} & Oct. $14-19$ & $\begin{array}{l}\text { LED - } 8 \text { Areas } \\
\text { (Bow Only) }\end{array}$ & 6 & $\begin{array}{l}\text { 1-Licenced for } \\
\text { either Trophy } \\
\text { or Non-Trophy }\end{array}$ \\
\hline & Oct. $21-26$ & LED - 8 Areas & 6 & 1-Trophy \\
\hline & Oct. 24-26 & " & 3 & 1-Non-Trophy \\
\hline \multirow[t]{3}{*}{1986} & Oct. $13-18$ & $\begin{array}{l}\text { LED - } 8 \text { Areas } \\
\text { (Bow Only) }\end{array}$ & 6 & $\begin{array}{l}\text { 1-Licenced for } \\
\text { either Trophy } \\
\text { or Non-Trophy }\end{array}$ \\
\hline & 0ct. $20-25$ & LED - 8 Areas & 6 & 1-Trophy \\
\hline & Oct. $23-25$ & $"$ & 3 & 1-Non-Trophy \\
\hline \multirow[t]{3}{*}{1987} & oct. 12-17 & $\begin{array}{l}\text { LED - } 8 \text { Areas } \\
\text { (Bow Only) }\end{array}$ & 6 & $\begin{array}{l}\text { 1-Licenced for } \\
\text { either Trophy }\end{array}$ \\
\hline & Oct. 19-24 & LED - 8 Areas & 6 & 1-Trophy \\
\hline & $\begin{array}{l}\text { Oct. } 22-24 \text { or } \\
\text { Oct. } 26-28\end{array}$ & $"$ & 3 & 1-Non-Trophy \\
\hline \multirow[t]{3}{*}{1988} & $\begin{array}{l}\text { Sept.19-0ct.1 or } \\
\text { Oct.3-15 }\end{array}$ & $\begin{array}{l}\text { LED - } 8 \text { Areas } \\
\text { (Bow Only) }\end{array}$ & 13 & 1-Any Antelope \\
\hline & $\begin{array}{l}\text { Oct.3-8 or } \\
\text { Oct. 17-22 }\end{array}$ & LED - 8 Areas & 6 & 1-Trophy \\
\hline & $\begin{array}{l}\text { Oct. } 6-8,13-15 \text {, } \\
20-22 \text {, or } 24-26\end{array}$ & $"$ & 3 & 1-Non-Trophy \\
\hline \multirow[t]{3}{*}{1989} & Sept.18-30 & $\begin{array}{l}\text { LED - } 8 \text { Areas } \\
\text { (Bow Only) }\end{array}$ & 13 & 1-Any Antelope \\
\hline & $\begin{array}{l}\text { Oct. 2-7 or } \\
\text { Oct.16-21 }\end{array}$ & LED - 8 Areas & 6 & 1-Trophy \\
\hline & $\begin{array}{l}\text { Oct.5-7, } 12-14 \text {, } \\
19-21 \text { or } 23-25\end{array}$ & $"$ & 3 & 1-Non-Trophy \\
\hline
\end{tabular}


antelope licences that was consistently higher than the number of available licences, and by complaints from unsuccessful licence applicants. This waiting period was rescinded for non-trophy antelope licence holders in 1986 in order to reduce the annual undersubscription that had developed for non-trophy antelope licences. After this anyone could apply for a non-trophy antelope licence on an annual basis.

In 1987, the resident licence fee was raised to $\$ 40.00$ and the non-resident fee was raised to \#138.00. Additional time periods were added for non-trophy seasons to spread the hunting pressure out over more days. However, an individual hunter was still licenced for only three days.

In 1988, a limited entry antelope archery special licence was added. This allowed archers to take any antelope and was a separate licence from trophy and non-trophy. Hunters could apply for all three licences (if they met the trophy eligibility requirement) but could possess only one licence. The draw order was archery, trophy and non-trophy. Those selected in any draw were then not eligible for subsequent draws.

\subsubsection{Population Inventory}

Systematic aerial censusing of pronghorns began in 1955. Mitchell (1980) reported that initially $0.8 \mathrm{~km}$ strips on either side of a line transect were searched in late July or early August. Fawns and adult antelope observed per transect were recorded and the sex of adults was determined. Sampling was concentrated in the Pakowki, Newe11, Aden and Ronalane areas, with an initial coverage of 3 percent in 1955 and 1956 and 100 percent coverage of the Lake Newell and Pakowki site between 1959 and 1964. In 1963, twelve sets of straight line transects were surveyed in representative sections of continuous antelope range from Lethbridge east to the Saskatchewan border and from the Montana border north to the Red Deer River (Webb 1963). From 1963 to 1969, provincial antelope surveys covered one third of the antelope range annually at 50 percent coverage (Barrett and Vriend 1980).

In 1964, the province was subdivided into 134 Wildlife Management Units (WMUs). At the same time, 20 WMUs in southeastern Alberta were grouped into seven Antelope Hunting Areas (Figure 4), including the 


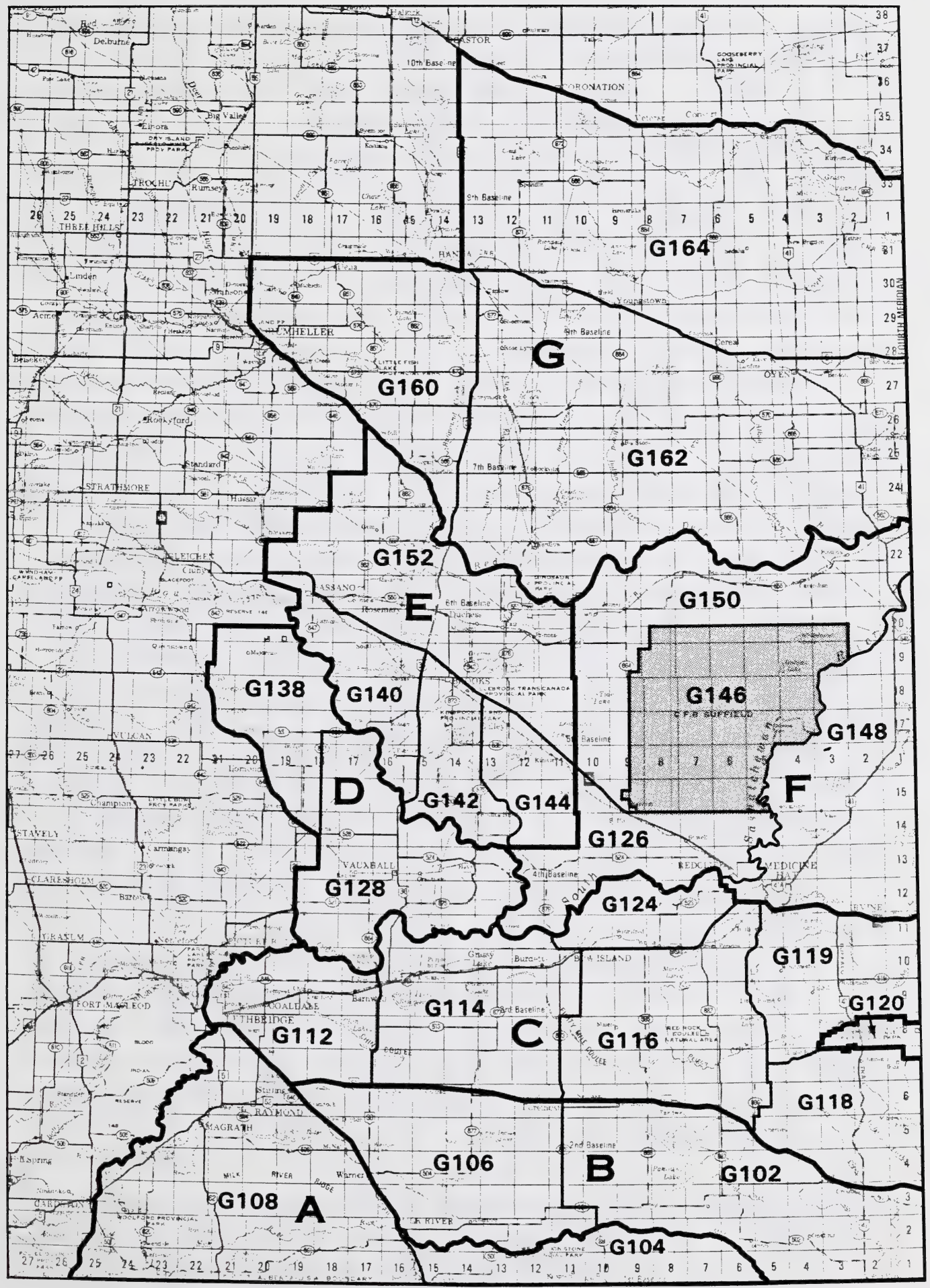

Figure 4. Antelope Hunting Areas (letters A - G) from 1964 to 1983. 
Eastern Irrigation District, which had been closed to hunting for the previous three years.

In 1970 and 1971, a standardized format was adopted to sample 18 percent of the total antelope range in the province. Representative habitat types were flown at 50 percent coverage for intensive pronghorn use areas and at 25 percent coverage for marginal habitat. Sixteen permanent sampling blocks were established in which $38.6 \mathrm{~km}$ long transects were flown at $3.22 \mathrm{~km}$ intervals. The Suffield Military Block was also surveyed in the same manner but the data were not used in provincial population estimates.

A provincial survey team was established in 1971 to provide more consistency to the data collection process. This survey team functioned until 1981 when the responsibility for aerial surveys was shifted to the regional biologists in Lethbridge and Red Deer. Survey design and operation for the period of 1970-1981 are reviewed in Cook (1981).

In 1984, WMU boundaries were adjusted in southeastern Alberta to reflect habitat use by individual overwintering herds of pronghorns. Area $G$ north of the Red Deer River (Figure 4) was split to create an additional hunting area, Area $H$, and provide more recreational opportunity by more effectively distributing hunters and the antelope harvest. These eight areas have been known as Antelope Management Areas (Figure 5) since 1984. Survey blocks were added or altered in management areas $B, D, E, F, G$ and $H$ to increase survey coverage and to equalize sampling intensity among the eight management areas. Beginning in 1986, the survey was cut back to cover four Antelope Management Areas each year.

Transects $0.8 \mathrm{~km}$ in width were flown in 1984 at $3.22 \mathrm{~km}, 6.44 \mathrm{~km}$ and $9.66 \mathrm{~km}$ intervals. This provided 25 to 50 percent block coverage. Aerial flights were scheduled at 0600 hours and 1600 hours and small fixed wing aircraft were used to classify all animals both on and off transect. Survey transects were flown at $60 \mathrm{~m}-90 \mathrm{~m}$ above ground level at speeds of $120 \mathrm{~km} / \mathrm{h}-160 \mathrm{~km} / \mathrm{h}$.

\subsubsection{Historical Management Goals, Objectives and Strategies}

Alberta pronghorn managers were following certain management regimes as early as the mid-1950s, but the first written management 


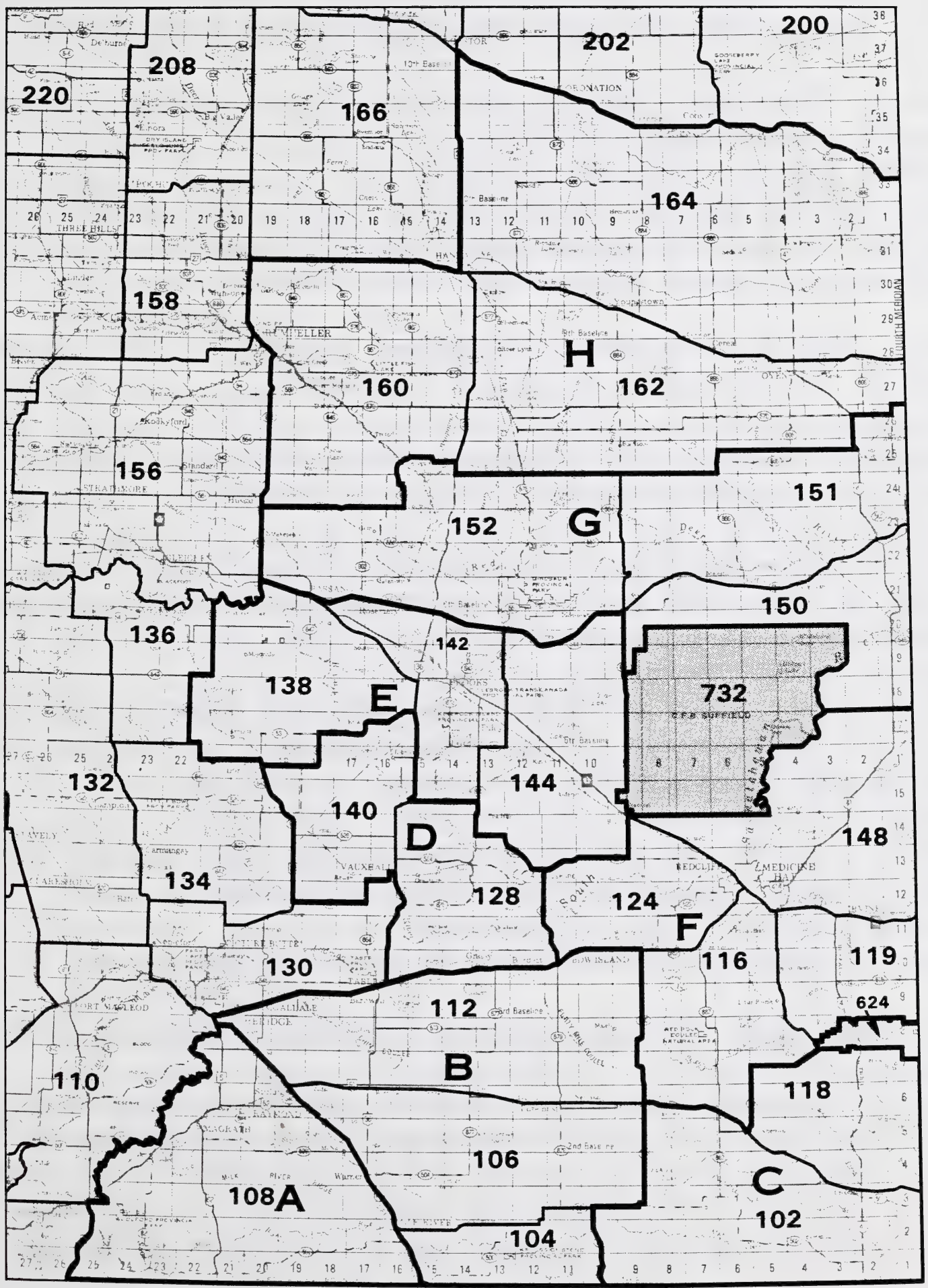

Figure 5. Antelope Management Areas (letters A - H) from 1984 to present. 
plan, a consensus of the antelope managers at that time, appeared in Wishart (1972). These goals, objectives and strategies were as follows:

"1. Annual population and harvest surveys continued on a sound statistical basis;

2. An optimum population goal for the province set at approximately 15000 antelope (excluding the Suffield Reserve), after which a maximum sustained harvest should be taken;

3. A lower limit of 5000 antelope (excluding Suffield) established below which the season will be closed;

4. Lands sufficient to support an optimum wintering population of antelope, reserved and managed for this purpose;

5. Migration patterns within the province, as well as interprovincial and international movements established by a trapping and marking program;

6. A high quality hunting experience while in pursuit of antelope maintained by not exceeding a density of one hunter per four square miles;

7. A high quality animal will be provided by closing the trophy season not later than the last week of October."

They still form the basis of the current management program.

\subsection{Current Status, Use and Management of Pronghorn Antelope in Alberta}

The previous section outlines what is known about the historical status and use of antelope populations and habitat. It also discusses the development of antelope management during the same period. The purpose of this section is to provide a detailed description of the current status of antelope populations and habitat, the present level and distribution of 
people's use of the resource and the present management program.

\subsubsection{Current Status of Pronghorn Antelope Populations in Alberta}

The estimated pronghorn antelope population in Alberta in July 1989 was 22300 . This ranks the province as first in Canada in terms of total numbers and sixth in North America behind Wyoming (315 000), Montana $(160000)$, South Dakota $(65000)$, Colorado $(47250)$ and New Mexico $(30000)$. Table 5 displays the population estimates for each Antelope Management Area and also provides buck:doe ratios and production information (fawn:doe ratios).

The estimated July 1989 population of 22300 antelope (Table 5) in the eight Antelope Management Areas (A-H) is lower than the July 1988 estimate of 23100 . Antelope populations can change rapidly from year to year but the overall trend in the last 10 years has been towards higher populations (Appendix I). Figure 6 illustrates the average density of pronghorns by WMU for the period 1963 - 1985. The best pronghorn densities are associated with uncultivated short grass prairie in units 102, 104, 108, 118, 119, 124, 128, 142, 144, 148 and 732 (Suffield). Generally, where cultivation has been intensive $(106,112)$ or where winter mortality can be high at the northern extension of pronghorn range in Alberta (151, 152, 160, 162, 164 and 166), antelope densities have averaged less than 0.31 animals per $\mathrm{km}^{2}$.

The 1989 provincial buck:doe ratio of 59:100 in the four antelope hunting areas surveyed is higher than the 1963-1989 average of 48:100 (Table 6). Comparison reveals most 1989 hunting area buck:doe ratios were below the long-term average. Suffield, which has a largely unhunted population, had a buck:doe ratio of 50:100 in 1989. Reference to Table 6 shows that the Suffield ratio has been much higher than the provincial average from 1963-1989.

Production, reflected in the 1989 fawn:doe ratio of 39:100, is well below to the long-term average (Table 6). More detailed buck: doe:fawn ratios and information on antelope densities by hunting area from 1963-1989 can be found in Appendix III. 
Table 5. Estimated pronghorn antelope populations and buck:doe:fawn ratios in Alberta in July 1989.

\begin{tabular}{|c|c|c|c|c|}
\hline $\begin{array}{l}\text { Antelope } \\
\text { Management } \\
\text { Area }\end{array}$ & $\begin{array}{l}\text { Estimated } \\
\text { Number } \\
\text { Animals }\end{array}$ & $\begin{array}{l}\text { Percent of } \\
\text { Provincial } \\
\text { Population }\end{array}$ & $\begin{array}{l}\text { Number } \\
\text { Bucks Per } \\
100 \text { Does }\end{array}$ & $\begin{array}{l}\text { Number } \\
\text { Fawns Per } \\
100 \text { Does }\end{array}$ \\
\hline A & 1600 & 7 & $48^{a}$ & $55^{a}$ \\
\hline B & 700 & 3 & $47^{b}$ & $36^{b}$ \\
\hline c & 4200 & 19 & 51 & 28 \\
\hline D & 950 & 4 & 96 & 71 \\
\hline$E$ & 2420 & 11 & 66 & 51 \\
\hline$F$ & 4600 & 21 & $39 a$ & $47^{a}$ \\
\hline G & 2330 & 10 & 62 & 52 \\
\hline$H$ & 2500 & 11 & $55^{a}$ & $72^{\mathrm{a}}$ \\
\hline Suffield & 3000 & 14 & $50 \mathrm{C}$ & $50 \mathrm{C}$ \\
\hline Total & 22300 & 100 & $41^{d}$ & $62^{d}$ \\
\hline
\end{tabular}

a 1988 data were used as these areas were not surveyed in 1989.

b1985 data were used as this area was not surveyed in recent years.

C 1986 data were used as this area was not surveyed in recent years. dThis ratio reflects only the 1989 data from areas C, D, E and G. 


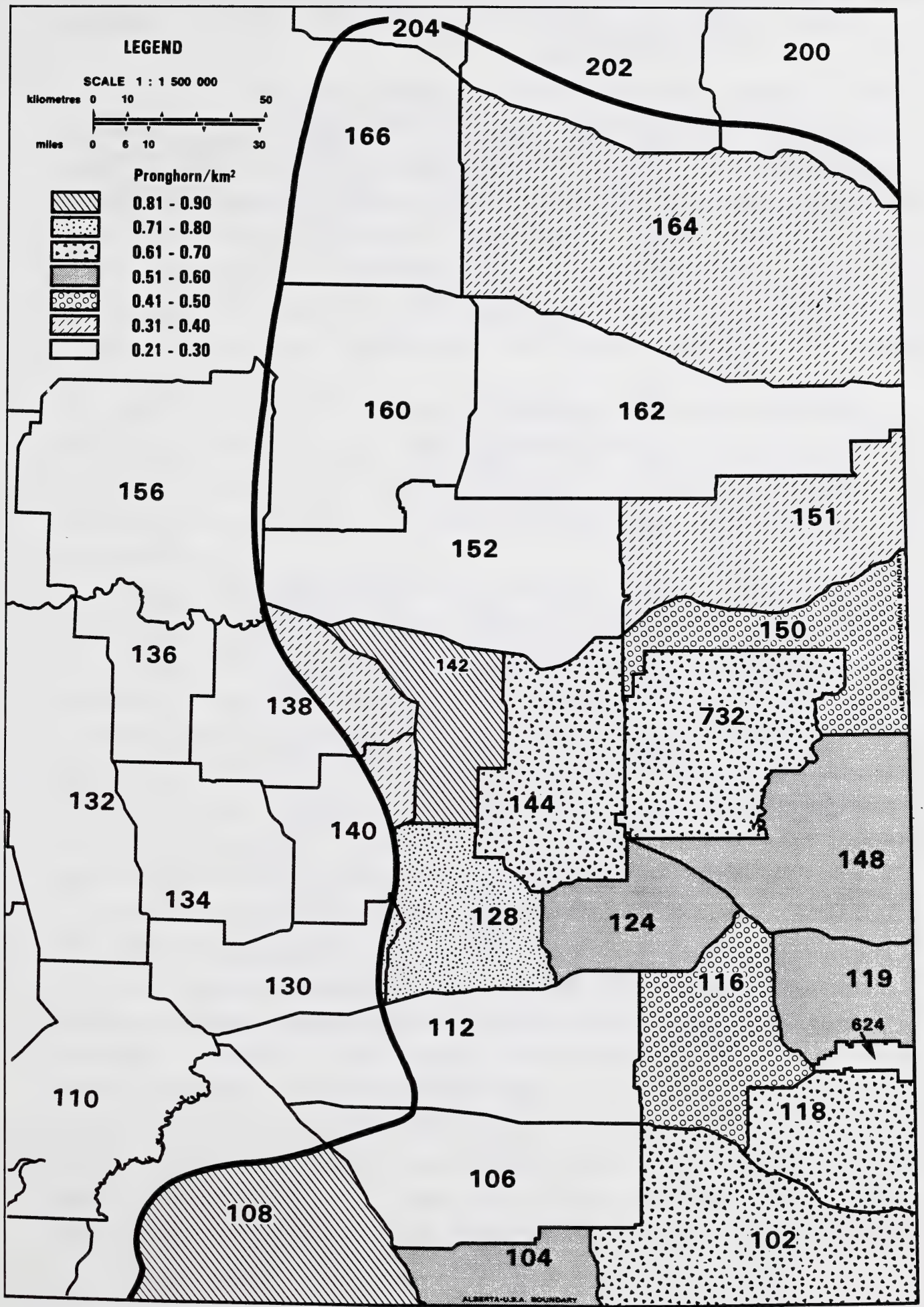

Figure 6. Average densities of pronghorns from $1963-1985$ by Wildlife Management Unit. 
Table 6. Comparison between the 1989 buck:doe:fawn ratios and the 1963-1989 average.

\begin{tabular}{|c|c|c|c|c|}
\hline \multirow{2}{*}{$\begin{array}{l}\text { Antelope } \\
\text { Management } \\
\text { Area }\end{array}$} & \multicolumn{2}{|c|}{ Bucks Per 100 Does } & \multicolumn{2}{|c|}{ Fawns Per 100 Does } \\
\hline & $\begin{array}{c}1989 \\
\text { Estimate }\end{array}$ & $\begin{array}{c}1963-1989 \\
\text { Average }\end{array}$ & $\begin{array}{c}1989 \\
\text { Estimate }\end{array}$ & $\begin{array}{c}1963-1989 \\
\text { Average }\end{array}$ \\
\hline A & $48^{a}$ & 46 & $55^{a}$ & 70 \\
\hline B & $47^{b}$ & 38 & $36^{b}$ & 54 \\
\hline C & 51 & 45 & 28 & 47 \\
\hline D & 96 & 57 & 71 & 73 \\
\hline$E$ & 66 & 48 & 51 & 73 \\
\hline $\mathrm{F}$ & $39^{a}$ & 43 & $47^{a}$ & 62 \\
\hline G & 62 & 39 & 52 & 62 \\
\hline H & $55^{a}$ & 50 & $72^{a}$ & 60 \\
\hline Suffield & $50^{C}$ & 65 & $50^{C}$ & 62 \\
\hline Total & $59 b$ & 48 & $39 d$ & 62 \\
\hline
\end{tabular}

a1988 data were used as these areas were not surveyed in 1989.

$b_{1} 1985$ data was used as this area was not surveyed recently.

C 1986 data was used as this area was not surveyed recently. 
Initial European settlement on the prairies fostered cattle husbandry since the low precipitation, strong winds and large climatic moisture deficit made crop production a high risk. With the advent of irrigation, however, intensive cultivation of the brown Chernozemic soils permitted the production of sugar beets, alfalfa, vegetable crops, wheat, oats and barley. Natural prairie has been plowed and competition for forage with cattle on the remaining range has become significant. Range fencing, which is associated with cattle production, has become more prevalent.

From 1961 to 1976 there was a 17 percent decline in the number of farms in the Medicine Hat, Taber, Lethbridge areas of southern Alberta. During the same period, however, there was a 4.5 percent increase in farmland and an 8 percent increase in cultivated acreage (McCuaig and Manning 1982).

Haag (1986) estimated the total Alberta antelope range, including cultivated land and native grass prairie, to be $52829 \mathrm{~km}^{2}$. He found that during the period 1970 to 1983 cultivated lands on pronghorn range increased from 1569678 ha (29.7 percent of the total range) to 1881047 ha (35.6 percent of the total range), an increase of 19.9 percent in the amount of cultivated 1and. The 312005 hectares converted to cultivation, 5.9 percent of the total range, represents a loss of 8.4 percent of the native grass prairie. He noted that the major increase in cultivation was in the northern part of the range.

Clark (1985) excluded some of the predominately cultivated area included by Haag (1986); consequently, he determined a total Alberta antelope range of $43588 \mathrm{~km}^{2}$ (71 percent or $30812 \mathrm{~km}^{2}$ of native grass prairie and 29 percent or $12776 \mathrm{~km}^{2}$ of cultivated land). Table 7 provides a summary of the area of native grass prairie and cultivated land in each of the Antelope Management Areas as calculated by Clark (1985). Barrett and Vriend (1980) identified 12 pronghorn winter ranges from the Red Deer River and south which totalled $3423 \mathrm{~km}^{2}$ excluding the Suffield Military Reserve. These winter ranges are shown within current WMU boundaries (Figure 7) and Table 8 indicates the amount of winter 
Table 7. Amount of native grass prairie and cultivated land in each Antelope Management Area in 1985.

\begin{tabular}{ccccccc}
\hline $\begin{array}{c}\text { Antelope } \\
\begin{array}{c}\text { Management } \\
\text { Area }\end{array}\end{array}$ & $\begin{array}{l}\text { Native Grass Prairie } \\
\left(\mathrm{km}^{2}\right)\end{array}$ & $\begin{array}{c}\text { Cultivation } \\
\text { Area }\end{array}$ & $\begin{array}{c}\text { Total } \\
\text { Area }\end{array}$ & $\begin{array}{c}\text { Area } \\
\left(\mathrm{km}^{2}\right)\end{array}$ & $\begin{array}{c}\text { \% Total } \\
\text { Area }\end{array}$ & $\begin{array}{c}\text { Total } \\
\text { Area } \\
\left(\mathrm{km}^{2}\right)\end{array}$ \\
\hline A & 1380 & 74 & 474 & 26 & 1854 \\
B & 1445 & 24 & 4501 & 76 & 5946 \\
C & 4522 & 91 & 422 & 9 & 4944 \\
D & 945 & 70 & 399 & 30 & 1344 \\
E & 2761 & 92 & 246 & 8 & 3007 \\
F & 5196 & 70 & 2253 & 30 & 7449 \\
G & 6283 & 79 & 1650 & 21 & 7933 \\
H & 8280 & 75 & 2831 & 25 & 11111 \\
\hline Total & 30812 & 71 & 12776 & 29 & 43588 \\
\hline
\end{tabular}




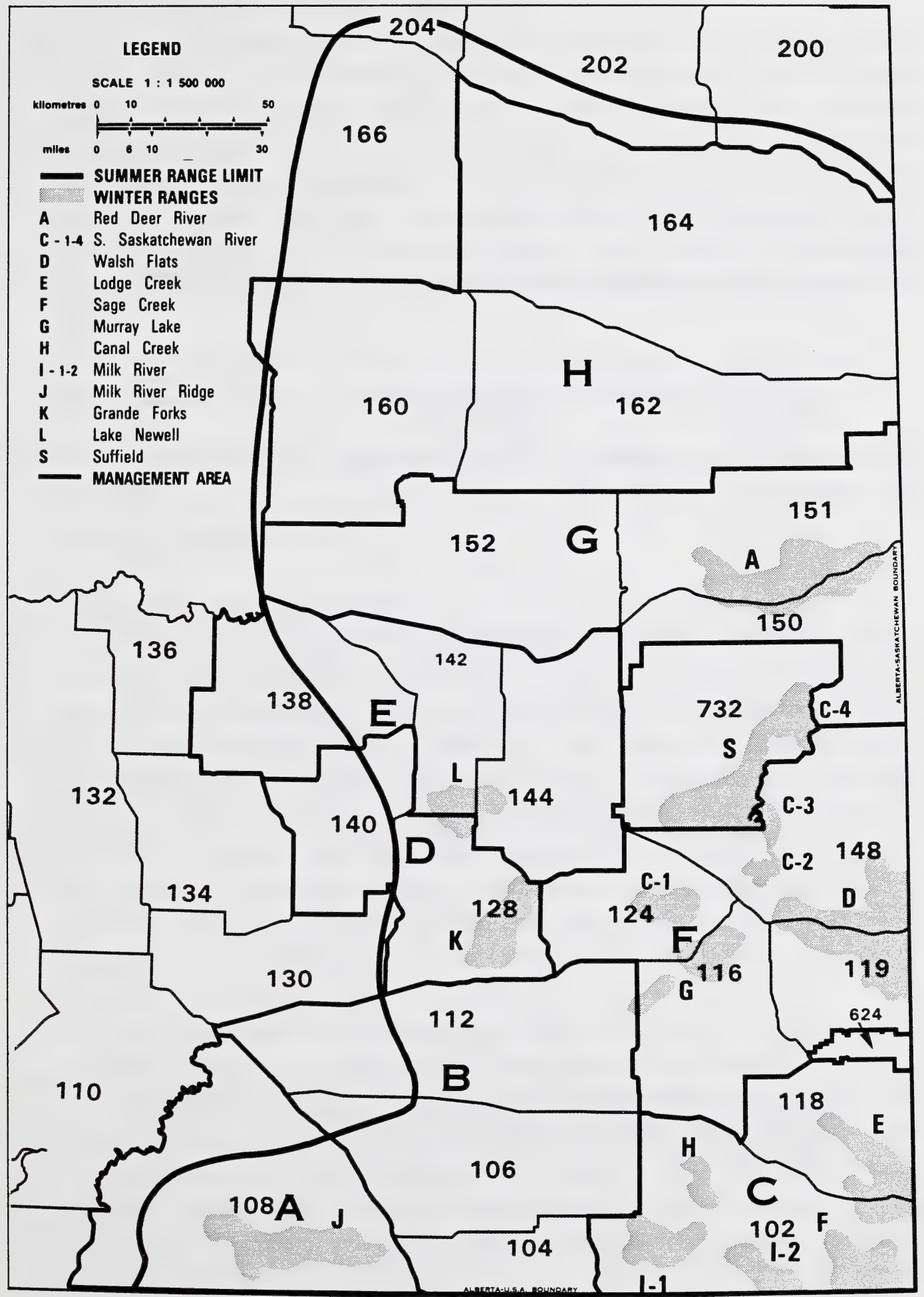

Figure 7. Known winter ranges for pronghorns in Alberta. 
Table 8. Areas of pronghorn winter ranges in Alberta in 1975.

\begin{tabular}{|c|c|c|}
\hline $\begin{array}{l}\text { Antelope } \\
\text { Management } \\
\text { Area }\end{array}$ & $\begin{array}{l}\text { Winter } \\
\text { Range Letters } \\
\text { (see Fig. 7) }\end{array}$ & $\begin{array}{l}\text { Area } \\
\left(\mathrm{km}^{2}\right)\end{array}$ \\
\hline A & $\mathrm{J}$ & 387 \\
\hline B & $\mathrm{Nil}$ & $\mathrm{Nil}$ \\
\hline c & $\mathrm{I}_{1}, \mathrm{I}_{2}, \mathrm{E}, \mathrm{F}, \mathrm{H}$ & 1089 \\
\hline D & K & 244 \\
\hline $\mathrm{E}$ & $\mathrm{L}$ & 224 \\
\hline $\mathrm{F}$ & $C_{1}, C_{2}, C_{3}, C_{4}, D, G$ & 1040 \\
\hline G & $A$ & 439 \\
\hline$H$ & $\mathrm{Ni1}$ & $\mathrm{Nil}$ \\
\hline Total & & $3423^{a}$ \\
\hline
\end{tabular}


range by Antelope Management Area.

Glaholt (1984) found that during the period 1950 to 1983 cultivated 7 ands on these winter ranges increased from 9.7 percent of the winter range to 14.4 percent, an increase of 48 percent in the amount of cultivated land. The 13721 ha converted to cultivation, 4.7 percent of the winter range, represent a loss of 5.2 percent of the native grass prairie. Kemp (1983), upon investigating the Walsh Flats winter range, noted an increase in cultivation from 15 to 22 percent of the winter range, very similar to Glaholt's 16 to 23 percent on this particular range.

\subsubsection{Current Uses of Pronghorn Antelope in Alberta}

Current uses of pronghorn antelope in Alberta include recreational hunting, aesthetic enjoyment, scientific research, education and commercial opportunities.

\subsubsection{Recreational Hunting}

Pronghorn antelope are hunted under the authority of a special licence obtained through a draw that limits the number of hunters in each Antelope Management Area or hunting area. Hunters may possess an Antelope Archery Special Licence, a Trophy Antelope Special Licence or a Non-trophy Antelope Special Licence. A hunter may apply for archery and non-trophy every year, but those successful in the draw for a trophy licence may not apply during the following two years. Non-resident Canadians may apply for a Trophy Antelope Special Licence, and non-residents and non-resident aliens may obtain a Trophy Antelope Special Licence through an outfitter-guide allocation. Non-trophy licences are available only to residents.

The hunting season is usually three to four weeks in September for archery, one week in October for trophy antelope and three to six days for non-trophy antelope. The non-trophy season starts later than the trophy season and may include more than one 3-day season to reach the harvest goal. An archery season is provided prior to the rifle season. Trophy licences are in much greater demand than non-trophy, partly because of tradition and partly because the antelope carcass produces 
very little meat compared to other ungulates.

Table 9 portrays the demand (number of applicants) and the amount of recreation provided (number of licences issued, recreation days provided and animals harvested) in 1989. Comparison of the provincial total in Table 9 with those in Table 2 (page 15) indicates that the demand for antelope licences increased to a very high level, particularly when the one- and two-year ineligibility periods for trophy licence applications are considered.

Hunter residence codes are shown in Figure 8 while Table 10 indicates antelope hunter distribution by residence code from 1980-1984, the most recent data available. Hunters originate from all over Alberta, but the highest percentage reside in the areas of the residence codes for Calgary, Edmonton and the two codes that encompass antelope range (5 and 6 ). Rough calculations from the approximate centre of each residence code's populated area to the centre of the hunting areas indicates the average distance travelled is about $220 \mathrm{~km}$ one-way to hunt antelope. Non-resident use involved 90 licences in 1989 with the majority from British Columbia. Harvest success rates were not measured but would likely be similar to residents.

\subsubsection{Nonconsumptive Use}

Phillips et al. (1977a) determined that 1.4 million Albertans (79 of the provincial population) were involved in nonconsumptive wildlife recreational activities such as observation, photography and study during 1975-76, providing 17 million days of recreation. Assuming the same level of involvement in 1989, the figures would be 1.9 million people and 22 million recreation days. The study did not break down nonconsumptive recreational activities but animal life enjoyment accounted for 40 percent of the activity. Antelope were listed as twelfth in the "like to see" species category and third in the "like to see more of" category of a survey of nonconsumptive Alberta recreationists (Phillips et al. 1977a). Pronghorns ranked second of 11 mammalian game species for which Albertans, involved in nonconsumptive use, would like to see increased populations. Filion et al. (1989) found that 2.2 million (91 percent) Albertans participated in a wide range of nonconsumptive wildlife-related activities, providing more than 
Table 9. Pronghorn antelope licence demand, recreation provided and hunter success in Alberta in 1989.

\begin{tabular}{|c|c|c|c|c|c|c|}
\hline $\begin{array}{c}\text { Antelope } \\
\text { Management } \\
\text { Area }\end{array}$ & $\begin{array}{l}\text { Special } \\
\text { Licence } \\
\text { Type }\end{array}$ & $\begin{array}{l}\text { Number } \\
\text { of } \\
\text { Applicants }\end{array}$ & $\begin{array}{l}\text { Number } \\
\text { Licences } \\
\text { Issued }\end{array}$ & $\begin{array}{l}\text { Number } \\
\text { Recreation } \\
\text { Days } \\
\text { Provideda }\end{array}$ & $\begin{array}{l}\text { Number } \\
\text { Animals } \\
\text { Harvesteda }\end{array}$ & $\begin{array}{c}\text { Hunter } \\
\text { Success } \\
\text { Rate }(\%)^{a}\end{array}$ \\
\hline A & $\begin{array}{l}\text { Archery } \\
\text { Trophy } \\
\text { Non-Trophy }\end{array}$ & $\begin{array}{r}11 \\
273 \\
225\end{array}$ & $\begin{array}{r}11 \\
268 \\
211\end{array}$ & $\begin{array}{l}48 \overline{-} \\
203\end{array}$ & $\begin{array}{l}150 \\
118\end{array}$ & $\begin{array}{l}5 \overline{6} \\
56\end{array}$ \\
\hline B & $\begin{array}{l}\text { Archery } \\
\text { Trophy } \\
\text { Non-Trophy }\end{array}$ & $\begin{array}{r}21 \\
203 \\
188\end{array}$ & $\begin{array}{r}21 \\
121 \\
139\end{array}$ & $\begin{array}{l}17 \overline{8} \\
170\end{array}$ & $\begin{array}{r}7 \overline{8} \\
110\end{array}$ & $\begin{array}{l}64 \\
79\end{array}$ \\
\hline C & $\begin{array}{l}\text { Archery } \\
\text { Trophy } \\
\text { Non-Trophy }\end{array}$ & $\begin{array}{r}38 \\
712 \\
725\end{array}$ & $\begin{array}{r}36 \\
601 \\
686\end{array}$ & $\begin{array}{r}1229 \\
572\end{array}$ & $\begin{array}{l}51 \overline{7} \\
353\end{array}$ & $\begin{array}{l}8 \overline{ } \\
51\end{array}$ \\
\hline D & $\begin{array}{l}\text { Archery } \\
\text { Trophy } \\
\text { Non-Trophy }\end{array}$ & $\begin{array}{r}17 \\
236 \\
272\end{array}$ & $\begin{array}{r}17 \\
121 \\
30\end{array}$ & $\begin{array}{r}24 \overline{2} \\
45\end{array}$ & $\begin{array}{r}10 \overline{6} \\
19\end{array}$ & $\begin{array}{l}8 \overline{8} \\
63\end{array}$ \\
\hline$E$ & $\begin{array}{l}\text { Archery } \\
\text { Trophy } \\
\text { Non-Trophy }\end{array}$ & $\begin{array}{r}22 \\
409 \\
492\end{array}$ & $\begin{array}{r}21 \\
381 \\
31\end{array}$ & $\begin{array}{r}68 \overline{1} \\
43\end{array}$ & $\begin{array}{r}33 \overline{6} \\
21\end{array}$ & $\begin{array}{l}8 \overline{8} \\
68\end{array}$ \\
\hline$F$ & $\begin{array}{l}\text { Archery } \\
\text { Trophy } \\
\text { Non-Trophy }\end{array}$ & $\begin{array}{r}33 \\
673 \\
830\end{array}$ & $\begin{array}{r}33 \\
591 \\
499\end{array}$ & $\begin{array}{r}119 \overline{8} \\
581\end{array}$ & $\begin{array}{l}44 \overline{3} \\
381\end{array}$ & $\begin{array}{l}7 \overline{7} \\
76\end{array}$ \\
\hline G & $\begin{array}{l}\text { Archery } \\
\text { Trophy } \\
\text { Non-Trophy }\end{array}$ & $\begin{array}{r}67 \\
752 \\
1006\end{array}$ & $\begin{array}{r}66 \\
496 \\
290\end{array}$ & $\begin{array}{l}86 \overline{1} \\
483\end{array}$ & $\begin{array}{l}47 \overline{2} \\
258\end{array}$ & $\begin{array}{l}\overline{9} \\
89\end{array}$ \\
\hline H & $\begin{array}{l}\text { Archery } \\
\text { Trophy } \\
\text { Non-Trophy }\end{array}$ & $\begin{array}{r}28 \\
480 \\
805\end{array}$ & $\begin{array}{r}25 \\
393 \\
539\end{array}$ & $\begin{array}{l}60 \overline{-} \\
488\end{array}$ & $\begin{array}{l}37 \overline{8} \\
281\end{array}$ & $\begin{array}{l}96 \\
52\end{array}$ \\
\hline Total & $\begin{array}{l}\text { Archery } \\
\text { Trophy } \\
\text { Non-Trophy } \\
\text { Total }\end{array}$ & $\begin{array}{r}237 \\
3738 \\
4543 \\
8518\end{array}$ & $\begin{array}{r}230 \\
2972 \\
2425 \\
5627\end{array}$ & $\begin{array}{r}758 \\
5469 \\
2585 \\
8812\end{array}$ & $\begin{array}{r}63 \\
2480 \\
1541 \\
4084\end{array}$ & $\begin{array}{l}27 \\
83 \\
64 \\
73\end{array}$ \\
\hline
\end{tabular}

aThe small sample of archers contacted during the telephone harvest survey precluded analysis of the data at the Antelope Management Area level; therefore, only totals are provided for the archery licence type. 


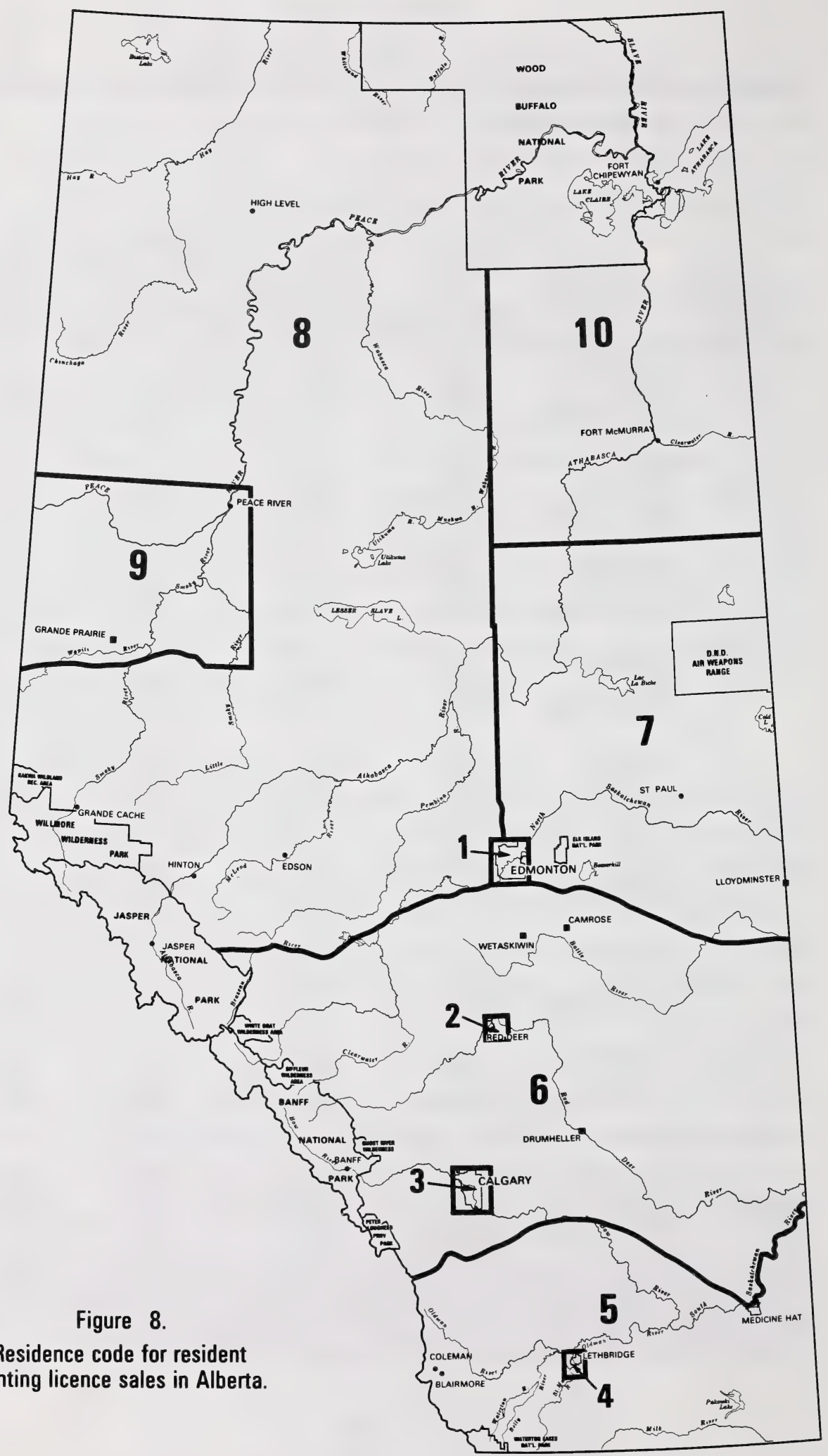


Table 10. Antelope hunter distribution by residence code, 1980-1984.

\begin{tabular}{|c|c|c|c|c|c|c|c|c|c|c|c|}
\hline \multirow[b]{2}{*}{ Year } & \multicolumn{11}{|c|}{ Number of Trophy Hunters by Residence Code } \\
\hline & 1 & 2 & 3 & 4 & 5 & 6 & 7 & 8 & 9 & 10 & Total \\
\hline 1980 & 188 & 33 & 321 & 89 & 387 & 414 & 54 & 47 & 14 & 5 & 1552 \\
\hline 1981 & 277 & 39 & 448 & 105 & 460 & 364 & 80 & 72 & 26 & 12 & 1883 \\
\hline 1982 & 217 & 30 & 427 & 126 & 555 & 452 & 75 & 89 & 11 & 13 & 1995 \\
\hline 1983 & 332 & 65 & 609 & 126 & 680 & 553 & 114 & 115 & 17 & 11 & 2622 \\
\hline 1984 & 477 & 66 & 829 & 208 & 803 & 857 & 183 & 164 & 35 & 28 & 3650 \\
\hline $\begin{array}{l}\text { Total } 1 \\
\text { Mean }\end{array}$ & $\begin{array}{r}1491 \\
\quad 298\end{array}$ & $\begin{array}{r}233 \\
47\end{array}$ & $\begin{array}{r}2634 \\
527\end{array}$ & $\begin{array}{l}654 \\
131\end{array}$ & $\begin{array}{r}2885 \\
577\end{array}$ & $\begin{array}{r}2640 \\
528\end{array}$ & $\begin{array}{l}506 \\
101\end{array}$ & $\begin{array}{r}487 \\
97\end{array}$ & $\begin{array}{r}103 \\
21\end{array}$ & $\begin{array}{l}69 \\
14\end{array}$ & $\begin{array}{rr}11702 \\
2340\end{array}$ \\
\hline
\end{tabular}

\begin{tabular}{|c|c|c|c|c|c|c|c|c|c|c|c|}
\hline \multirow[b]{2}{*}{ Year } & \multicolumn{10}{|c|}{ Number of Non-Trophy Hunters by Residence Code } & \multirow[b]{2}{*}{ Tota1 } \\
\hline & 1 & 2 & 3 & 4 & 5 & 6 & 7 & 8 & 9 & 10 & \\
\hline 1980 & 115 & 28 & 210 & 60 & 222 & 217 & 54 & 47 & 14 & 5 & 923 \\
\hline 1981 & 193 & 35 & 298 & 54 & 261 & 378 & 80 & 72 & 26 & 12 & 1346 \\
\hline 1982 & 244 & 51 & 386 & 48 & 218 & 363 & 75 & 89 & 11 & 13 & 1442 \\
\hline 1983 & 199 & 44 & 448 & 74 & 256 & 398 & 114 & 115 & 17 & 11 & 1564 \\
\hline 1984 & 615 & 147 & 1134 & 187 & 622 & 1284 & 183 & 164 & 35 & 28 & 4406 \\
\hline Total & 366 & 305 & 2476 & 423 & 1579 & 2640 & 506 & 487 & 103 & 69 & 9681 \\
\hline Mean & 273 & 61 & 495 & 85 & 316 & 528 & 101 & 97 & 21 & 14 & 1936 \\
\hline
\end{tabular}


130 million days of recreation in 1987 . The study did not specify the level of activity attributed to pronghorns.

\subsubsection{Research}

Pronghorn antelope research has been conducted mainly by universities and the Fish and Wildlife Division in Alberta. Past studies have focused on behavior, habitat use, fawn predation and survival, winter survival, movements and range improvement techniques. Pronghorns are an excellent educational study of a species adapted to live in the dry prairie area of Alberta.

\subsubsection{Commercial Uses}

There is currently very little commercial use made of pronghorns. A few animals are present in zoos for display purposes. Although data are not tabulated, Fish and Wildlife staff felt most of the 50-100 non-residents that came to hunt antelope historically, did so while accompanying a resident rather than a commercial guide. There was an allocation of 4 percent of the trophy antelope harvest for non-residents/non-resident aliens accompanying a commercial guide in 1990.

\subsubsection{The Value of Pronghorn Antelope to Albertans}

The previous section on current uses of pronghorns in Alberta indicated a high demand for a limited resource which occurs in the prairie area of Alberta. This high demand and the hundreds of thousands recreation days provided through both consumptive and nonconsumptive use can be translated into a dollar value for the Alberta economy. This section will outline some of the positive dollar benefits and briefly discuss costs associated with antelope damage.

Phillips et al. (1977b) referred to market benefits (1icence fees, cost of fuel, food, lodging, ammunition, capital expenditures) and extra-market benefits in determining the value of the wildlife resource to resident hunters. Extra-market benefits were defined as the value of hunting activity over and above hunting costs. They determined that the market benefits excluding licence fees was $\$ 343.23$ per big game hunter 
per season ( $\$ 153.36$ in variable costs and $\$ 189.97$ in capital costs). In addition, the extra-market benefits amounted to $\$ 200.85$ per person per season. Each hunter took an average of 4.5 trips to spend a personal total of $\$ 544.08$ or a mean of $\$ 120.91$ per trip (adjusted using the consumer price index change from 1975 to 1989 of 2.579 the cost per trip in 1989 would be $\$ 311.83$ per trip). Assuming the same cost ratio in 1989, antelope hunting, usually one trip, would have generated a total of $\$ 1.75$ million in benefits $(\$ 311.83 \times 5627$ hunters $)$. Non-residents held only 90 licences in 1989 so their contribution was relatively small.

Mature male pronghorns in Alberta ranged from $24 \mathrm{~kg}-35 \mathrm{~kg}$ (mean = $30.3 \mathrm{~kg}$ ) dressed weight while mature females weighed from $22 \mathrm{~kg}-30 \mathrm{~kg}$ (mean $=25.8 \mathrm{~kg})$. Dressed weight is defined as the carcass with head, skin and viscera removed. Kid weights ranged from $16.8 \mathrm{~kg}-20.4 \mathrm{~kg}$ with a mean of $18.75 \mathrm{~kg}$ (Mitchell 1980). The current dressed weight of beef averages about $\$ 3$ per $\mathrm{kg}$. This would give an approximate meat value of $\$ 92$ for each adult male pronghorn, $\$ 77$ for each adult female pronghorn and $\$ 56$ for each fawn. The estimated 1989 harvest was 2536 adult males, 1411 adult females and 137 fawns producing an overall meat value of $\$ 350000$.

It is very difficult to obtain dollar values for nonconsumptive use of wildlife because it is an activity often associated with many other things we do. Furthermore, nonconsumptive use is not usually species specific, so it would be difficult to assign a value to a particular animal. Both Philips et al. (1977b) and Filion et al. (1989) calculated values for nonconsumptive use. Philips et al. (1977b) provided only an extra-market value of three dollars per participant per day for all wildlife or a total of $\$ 50035800$ which, adjusted to 1989 dollars, would be $\$ 122$ million. Antelope were twelfth on a list of animals people would most like to see. Filion's study determined expenditures for trips where the primary intent was nonconsumptive wildlife use. Twenty-two percent of Albertans participated in these types of trips and spent $\$ 771$ per year for equipment, supplies and services in 1987. Adjusted to 1989 this would be $\$ 840(771 \times 1.09)$ per participant per year or a total of $\$ 448$ million. Ten percent of the trips involved encounters with large mammals (Filion et al. 1989). If pronghorns are 
assumed to make up 10 percent of the larger mammal encounters, then expenditures attributed to them would be $\$ 4.5$ million.

Although these figures are not precise, it is obvious that nonconsumptive use of pronghorn antelope alone and in conjunction with other wildlife provide an important stimulus in the Alberta economy. The total value of hunting and nonconsumptive use of antelope appears to be in the $\$ 6.6$ million range annually.

The incidence of pronghorn damage complaints is very low. During four years there was a total of only 47 complaints related to crop damage by antelope $(1982 / 83$ - 12; 1983/84 - 10; 1984/85 - 15; 1985/86 10; Annual Incidence Report System). This is approximately 3 percent of total ungulate-related complaints and spans a period when pronghorns were at record high numbers in Alberta. The actual dollar loss of crops damaged by pronghorns from 1980 to 1983 was $\$ 11235$. The amount paid in compensation from the Wildlife Damage Fund for this same period was \$7413. The low level of damage complaints against pronghorns likely reflects the preference of pronghorns for natural forage as well as a tolerance by prairie farmers for this species.

\subsubsection{Current Management Programs for Pronghorn Antelope in Alberta}

The Fish and Wildlife Policy (Fish and Wildlife Division 1982) set a general goal of maintaining the current population and habitat for pronghorns. The Status of the Fish and Wildlife Resource in Alberta (Fish and Wildlife Division 1984) indicated antelope numbers should be maintained between 10000 and 18000 animals. The current management program is designed to meet population and habitat goals, maintain a quality hunting experience, enhance hunter-landowner relations and minimize crop damage caused by pronghorns.

\subsubsection{Pronghorn Antelope Population Inventory}

Antelope population inventory annually occurs in half of the eight Antelope Management Areas, in accordance with the Provincial Survey Format outlined in Appendix IV. This survey format results in observation of about 12 percent of the estimated total population for all management areas and up to 25 percent of the estimated populations in the manage- 
ment areas covered by the current year's survey.

\subsubsection{Pronghorn Antelope Habitat Inventory}

Mapping and assessment of pronghorn habitat has been done at several different scales in the province. A $1: 1000000$ scale ecological land classification (ELC)-type landscape map of Alberta depicting 12 broad climatic regions and 278 physiographic/landform subregions was prepared by Pedocan (1984). One of four arbitrary current habitat suitability classes (best, moderate, poor, inadequate) was assigned to each subregion. Provincially there were $27394 \mathrm{~km}^{2}$ of "best" (4 percent of Alberta), $29059 \mathrm{~km}^{2}$ of "moderate" ( 5 percent of Alberta), $16960 \mathrm{~km}^{2}$ of "poor" (3 percent of Alberta), and $535180 \mathrm{~km}^{2}$ of "inadequate" (88 percent of Alberta). Mean summer densities of pronghorns for the four habitat suitability classes were estimated to be 0.5 antelope per $\mathrm{km}^{2}$ (best), 0.3 antelope per $\mathrm{km}^{2}$ (moderate), 0.1 antelope per $\mathrm{km}^{2}$ (poor) and 0 antelope per $\mathrm{km}^{2}$ (inadequate), producing a provincial population estimate, based solely on habitat, of 24109 pronghorn antelope. This scale of habitat mapping is useful only for a provincial overview and cannot be used at the WMU level.

For operational use, a mapping scale at the quarter-section to onesection size is desirable because it can be used effectively for planning and conducting aerial surveys and directing habitat protection/ development efforts. The Southern and Central Fish and Wildlife regions have completed mapping at the one-section scale for all of the pronghorn range in Alberta. The mapping technique involves the identification of native prairie, hayland and cropland. The first mapping was done in 1970 by the Southern Region and was recently updated in 1983 for both regions by Haag (1986). The Central Region updated Haag's work in 1986. Updates are planned to occur every 3 to 10 years depending on the magnitude of 1 and use change. Within the overall range, Barrett and Vriend (1980) made a more detailed assessment of sage availability and identified the important winter ranges. Efforts to expand this knowledge continue. Antelope winter ranges are also identified on the "Wildlife Key Area" maps, which were first produced in 1972 and have been updated periodically since that time, most recently in 1981. 
The habitat inventory discussed up to this point has dealt mainly with programs that determine how much and where the habitat is. This reveals very little about the quality of the habitat which is the capacity to provide food (particularly critical in winter) and to a lesser extent cover for pronghorns. Barrett $(1974,1982)$ examined the quality and capacity of antelope winter range, but there has been no systematic annual program designed to monitor the quality of antelope range.

\subsubsection{Pronghorn Antelope Habitat Protection and Development}

Habitat protection approaches are different for public land than private land, but the intent is to retain existing quantities and quality of habitat on both. On public land, important antelope habitat has been identified through habitat assessment and the Division's interest has been declared through the key area maps and the public land reservation system. Through the referral process the Division makes recommendations that retain habitat, reduce the impact of various 1 and uses or mitigate habitat losses resulting from the land uses. The land uses include activities related to the following: seismic lines, wellsites, pipelines, power lines, coal mines, water impoundments, roads, cultivation for annual cropland, more intensified grazing, urbanization, industrial plant sites, and high density outdoor recreation developments.

There are also smaller parcels of public land where wildlife values are part of the planning process such as the Range Improvement Program administered by the Public Lands Division. Wildlife concerns also form part of the input for major projects managed by Alberta Environment such as the Three Rivers Dam.

The approach for habitat protection on private land occurs through planning and dealing directly with private landowners. The planning level inputs were made into the regional planning commission plans and at the county, municipal district, improvement district and special area levels in the 1970s and early 1980s. Generally, the plans identified important wildlife areas, including pronghorn range, and stressed their importance to the local people, although there were no land use bylaws that specifically protected habitat solely for wildlife.

Dealing directly with the private landowner focuses on four areas. 
The first area involves the provision of information on the habitat requirements of antelope. The second area involves assistance in the prevention of antelope damage. The third area is the promotion of better hunter-landowner relations through hunter training, the Use Respect Program and enforcement of trespass laws. The fourth area is the provision of direct incentives to retain and/or improve wildlife habitat by providing landowner cooperators with recognition items (signs, hats, pins, crests), cash payments, tax relief, and developments such as fencing, watering sites and stream crossings to improve on-farm management of livestock. This program started as a pilot project in the county of Red Deer in 1978 with the retention of 4452 ha of habitat. It has recently been expanded to other municipal jurisdictions in the Central, Northeast and Southern regions. It is jointly funded by the Alberta Fish and Wildlife Division and Wildlife Habitat Canada and is administered by the Division. Pronghorns are one of the species that may benefit from such a program, although this program has not yet expanded into antelope range.

There have been no habitat development projects to date that were designed specifically to benefit antelope, because existing current habitat levels can support population goals. However, there continues to be a gradual loss of native rangeland to other uses and development may be desirable in the future. The present emphasis remains in the area of protecting the habitat that exists now.

\subsubsection{Pronghorn Antelope Population Management and Recreational}

\section{Hunting}

The pronghorn antelope herd is limited by habitat quantity and quality, weather severity, competition with domestic ungulates, predation, parasites and disease, accidents and hunting. Although the effect of these limiting or mortality factors can be manipulated to varying degrees by management, much of the effort in Alberta is currently directed towards hunting because it has replaced much of the mortality previously attributed to other factors. This section will deal with the management and allocation of hunting opportunity for pronghorn antelope in Alberta. Section 2.3.5.6, which follows, will deal with the other mortality factors. 
Phillips et a1. (1977b) found that the three major reasons for hunting were for enjoyment (44 percent), to get meat (37 percent) and to get a trophy (17 percent). The desire for trophies is probably higher for antelope than the 17 percent for big game generally. The current system of allocating recreational hunting of pronghorns attempts to provide a variety of opportunities while minimizing hunter-landowner conflicts and using hunting harvest as one tool to reduce antelope damage. Some general principles regarding hunting seasons have been applied to antelope.

The number of hunters must be controlled using a limited entry draw (special licence) because the pronghorn antelope is a very vulnerable herd animal that lives in open terrain and would be overharvested under a general licence. Hunter numbers are also controlled to maintain a reasonably high quality hunting experience. The season length is short, usually one to two weeks, to minimize disturbance of landowners. The general season occurs during the month of October after the antelope rut is completed, after most farming operations are completed and before the males begin to shed their horn sheaths. There is provision for an "archery only" time period preceding the general season.

\subsubsection{Recreation and Harvest Goals for Pronghorn Antelope Hunting}

The main recreational harvest goal is to provide a quality hunting opportunity and a high chance of success in harvesting a trophy buck. Quality has been enhanced by limiting hunter densities to one hunter per $10 \mathrm{~km}^{2}$ of antelope habitat, by opening trophy seasons before non-trophy, by encouraging hunting by foot (e.g., no carrying of weapons on offhighway vehicles in the morning, no discharge of weapons within 46 metres of a vehicle) and by working with landowners to maintain access to private 1 and (e.g., promoting the Use Respect Program, asking for input during determination of annual permit numbers). The goal is to maintain hunter success rates in excess of 70 percent. To fairly distribute the chances of being drawn for the limited number of licences, hunters successful in receiving a trophy licence may not apply for one during the following two years.

Additional recreational hunting opportunity is provided through a resident non-trophy antelope season. Similar techniques are used to 
maintain a quality hunting experience, but the main goal is to manage the number of animals in the herd to stay within the carrying capacity of the winter range. Hunter success rates consistently exceed 80 percent for this hunt. Since the demand for this licence type is lower than that for a trophy licence, hunters may apply every year.

Resident hunters are allowed to apply for an archery licence, a trophy licence and a non-trophy licence in the same year if they are eligible but may only possess one licence. The archery draw is made first, followed by trophy and non-trophy. Successful applicants then become ineligible for the subsequent draws. Archers are provided with a season prior to the general season.

Annual harvest goals are the difference between the estimated July population and the postseason population goal. The 1989 postseason goal appears in Table 11 and is based on the estimated capacity of the known winter ranges. During periods of very high populations (e.g., 1986) the harvest goal cannot be met if regular seasons and maximum hunter density restrictions are followed. Options such as additional licences, additional tags and additional seasons must be considered in these cases.

The Harvest Information System for Pronghorn Antelope - Systematic population inventories are conducted in half the Antelope Management Areas annually and used to estimate July population levels. Twenty percent of the hunters are contacted annually during the telephone harvest questionnaire. The harvest survey is accurate to plus or minus 15 percent at the management area level and 5 percent provincially; such degrees of accuracy are suitable for current management purposes. The information from the harvest survey provides an indication of population levels in unsurveyed management areas and determines whether annual harvest goals have been achieved. Since age/sex herd composition can be determined during July aerial surveys, jaws are not collected regularly to determine age structure in the population. However, jaws may be collected periodically for special projects (e.g., accurate determination of age distribution in the harvest). 
Table 11. Postseason pronghorn antelope population goals in Alberta in 1989.

\begin{tabular}{|c|c|c|c|c|}
\hline \multirow{2}{*}{$\begin{array}{l}\text { Antelope } \\
\text { Management } \\
\text { Area }\end{array}$} & \multicolumn{4}{|c|}{ Number of Animals } \\
\hline & Bucks & Does & Fawns & Total \\
\hline A & 162 & 649 & 389 & 1200 \\
\hline B & 68 & 270 & 162 & 500 \\
\hline C & 351 & 1406 & 843 & 2600 \\
\hline D & 122 & 486 & 292 & 900 \\
\hline$E$ & 365 & 1459 & 876 & 2700 \\
\hline$F$ & 541 & 2162 & 1297 & 4000 \\
\hline G & 237 & 947 & 616 & 1800 \\
\hline H & 237 & 947 & 616 & 1800 \\
\hline TOTAL & 2083 & 8326 & 5091 & 15500 \\
\hline
\end{tabular}


Mortality

Non-hunting mortality factors that limit the pronghorn antelope population are habitat quantity and quality, weather severity, predation, parasites and disease, and accidents.

Habitat - The amount and quality of habitat interacting with annual variations in weather severity ultimately determines annual natality, survival and recruitment. Habitat inventory, retention and development programs are covered in sections 2.3.5.2 and 2.3.5.3.

Weather Severity - Weather severity is monitored in a general way during the critical winter months. The Fish and Wildlife Division has responded to severe winters during some years (e.g., the winter of $1984 / 85$ ) by providing emergency winter feed. The general approach has been to recognize that annual winter mortality is a natural event and intervention should occur only under severe emergency conditions (Gurba and Neave 1979). It is difficult to feed antelope because their main winter food (sagebrush) is so different from potential emergency feed, which makes it difficult for them to adapt physiologically to a new food source. Murray (1986) conducted some experimental feeding trials in Alberta during the winter of 1985-86, but the results were inconclusive due to the mild winter. The rations used in these trials are identified in Appendix $V$.

Predation - Barrett (1978, 1982) documented high mortality of fawns due to coyote predation and some fawn loss to bobcats, but he suggested this was not limiting the population. Coyotes also take some adults in Alberta but total losses are felt to be small. Predation may slow down population recovery following large scale population declines. There are no current programs to reduce predators to increase antelope populations. However, hunting, trapping and agricultural pest control practices likely reduce local populations of coyotes and bobcats and may increase survival in areas where such practices occur.

Parasites and Disease - Parasites and diseases of antelope are monitored by the Division and the Provincial Veterinary Laboratories as complaints are received or carcasses are submitted. Universities may get involved on a project-specific basis. However, there is no systematic collection of antelope to monitor parasites and disease. Mitchell (1980) suggested 
these latter two were relatively unimportant as causative agents of mortality.

Accidental Death - The Division monitors complaints regarding vehicle collisions and other accidental deaths, but there is no systematic monitoring taking place.

\subsubsection{Management of Damage Caused by Antelope Populations}

Crop damage caused by antelope is quite limited but may be locally severe. Because it usually occurs in field situations, practical costeffective prevention methods have not yet been found. Compensation for antelope damage to standing and swathed crops is available and covers a percentage of the crop value. The major emphasis has been to maintain antelope populations within goal levels so they remain on native range away from agricultural crops.

\subsection{Management Issues and Future Implications}

There have been major advances in knowledge about antelope populations in Alberta over the past 30 years. During the same period the consumptive interest in the resource has increased fourfold and has exceeded the supply for more than 20 years. Awareness of antelope populations and nonconsumptive interest has also increased substantially, particularly in the last decade. At the same time, intensified use of the landscape for agriculture has significantly increased competition for the land base that constitutes pronghorn antelope habitat. Several major management issues must be addressed if antelope populations are to be maintained to meet future consumptive and nonconsumptive public needs.

\subsubsection{Recreational Use}

The harvest of antelope must be controlled by limiting the number of hunters in some way, because the herd would be overharvested under an open general licence season. Three important considerations in determining the hunting regime are hunting opportunity, quality of the hunting experience and landowner support. These considerations must be dealt with in the context of the goal to maintain a stable postseason 
antelope population.

The hunting regime must be designed both to provide equitable hunting opportunities with an acceptable quality of hunting experience and to maintain a cooperative working relationship with landowners that ensures access to privately owned and leased land. The current hunting regime, using a, limited entry draw and wait-out periods for licence eligibility, has been effective in allocating opportunity and maintaining hunter densities at levels acceptable to both hunters and landowners. However, because of the short hunting season and limits on hunter density, it has been difficult to achieve desirable harvest levels during periods of very high populations. Licencing flexibility such as quota licences and multiple tags and the ability to extend seasons must be retained to keep the herd within the capabilities of its winter range.

Information on the biology and distribution of antelope in Alberta must become readily available to the public. Opportunities for nonconsumptive users to interact (e.g., viewing sites and guides) with antelope populations must be increased. However, care must be taken to avoid increased disturbance of both the animals and the landowners.

\subsubsection{Habitat Retention and Enhancement}

The precision of current pronghorn antelope habitat inventory (mapping and assessment of suitability) is inadequate, particularly for winter range. Initial emphasis should be on better delineation of winter range and assessment of its carrying capacity during the critical winter period. Current inventories of summer range identify the extensive nature of the range but do not adequately identify the essential components and important use areas of the range. Better habitat inventory will allow more accurate goal setting for habitat and populations at the WMU level and will provide a better focus for habitat retention and enhancement programs.

The retention of antelope habitat on privately owned and leased public land is essential as the majority of the habitat falls in these two land ownership categories. Habitat enhancement, particularly on winter ranges, must be pursued to mitigate the small but steady losses 
that have occurred and probably will continue to occur on these ranges. Enhancement can mitigate small losses and even provide for modest population increases, but the long-term existence of pronghorns will depend on a successful habitat retention program.

\subsubsection{Population Management}

Current population inventory programs to determine population size, distribution, age/sex structure and productivity should continue, but the methodology and data should be tested to determine the level of precision. Increased precision could result in more overall recreational opportunity as population characteristics are better defined. Efforts to determine distribution and relative range use should be expanded to assist in the identification of important components and areas of antelope range, particularly winter range. Suitable methodology and strategies should be explored to reduce the magnitude of losses during severe winters.

\subsubsection{Protection of Property}

Antelope damage on private land is quite limited and is minimized by keeping populations at acceptable levels. Compensation is provided for damage to standing and swathed crops. However, damage losses can be locally extensive, so improvement of the compensation program and use of nonmonetary compensation (e.g., habitat enhancement to keep antelope away from crops or to improve forage for both antelope and domestic livestock) may encourage habitat retention and maintain access for recreational use of the resource in the future.

\subsubsection{The Future}

Failure to address the above major management issues will result in the long-term decline of both consumptive and nonconsumptive recreational opportunity because habitat and antelope populations will decline, while conflicts between the users, the landowners and the resource may intensify. The "Management Plan" that follows incorporates 
the desirable features of the current management program as well as identifying new strategies to address the management issues identified here. The plan is intended to reflect the needs for pronghorn antelope management in Alberta over the next 10 years. 


\subsection{MANAGEMENT PLAN}

\subsection{Policy Framework}

The Fish and Wildlife Policy for Alberta (Fish and Wildlife Division 1982) established, in the Wildlife Policy portion, goals for the administration of wildlife resources in Alberta. Quotes from this policy provide a framework for the formation of specific management plan goals for pronghorn antelope and are set out under five general categories.

1. Resource Protection

"1) ... The primary consideration of the Government is to ensure that wildlife populations are protected from severe decline and that viable populations are maintained."

2. Resource Allocation

"2)(a) The wildlife resource, as a Crown resource, will be utilized in a manner which contributes the most benefit to the citizens of Alberta."

"2)(e) Wildlife will be allocated through a defined process whereby specific resources are deployed to specified uses in order to achieve stated public benefits."

"17) Wildlife must be allocated among different primary users in response to government policy. Until such time as supply and demand can be better rationalized, the following interim allocation guidelines will prevail in order of priority:

...(b) Resident recreational use of game will have precedence over non-resident use. Wildlife stocks not fully allocated or utilized to higher priority uses may be allocated commercially to non-residents." 
"18) The allocation of wildlife stocks to the different primary uses does not imply that other uses cannot occur within areas where such uses are entitled."

3. Recreational Use

"8) A variety of wildlife recreational opportunities, in addition to hunting, will be available for the benefit and enjoyment of Albertans."

"21) A variety of hunting opportunities will be available for the recreational benefit and enjoyment of Albertans ..."

4. Commercial Use

"22) The Division will encourage an environment that promotes the growth of the tourist industry...."

5. Protection of Private Property

"4) The Government, through the Division, will assist in preventing or controlling wildlife from damaging property and endangering human life."

"5) Responsibility for damage in any form caused by wildlife will be shared in relationship to what people can reasonably do for themselves and to the amount of any additional damage beyond that which would normally be expected to occur in an area."

\subsection{Management Goals and Objectives}

\subsubsection{Resource Protection}

Goal: To ensure that viable populations of pronghorn antelope are maintained throughout their current range. 
Objective:

a) Maintain the viability of the eight management area populations associated with the 12 known winter ranges as shown in Figure 7 . This objective will be reached by doing the following:

a.i protecting pronghorn populations from overharvest, illegal hunting, extreme winter mortality, disturbance and disease, and

a.ii maintaining habitat quality on all wintering areas.

\subsubsection{Resource Allocation}

Goal: To maximize the benefits to Albertans through the optimum allocation of the pronghorn antelope resource.

Objectives:

a) Provide a variety of recreational hunting opportunities to 4770 residents that result in a harvest of 3340 pronghorns annually.

b) Provide the opportunity for 1.5 million Albertans to spend 80 million days on directly related nonconsumptive wildlife* activities.

c) Provide an opportunity for 100 non-resident hunters to harvest 70 trophy antelope during 300 recreation days, while providing an economic return to outfitters, guides and other Albertans providing goods and services.

d) Promote and encourage scientific and educational activity that will enhance our knowledge of pronghorns.

* "Nonconsumptive" goals and objectives are not developed by species so this objective includes all wildlife species involved in nonconsumptive activities, not just antelope. 


\subsubsection{Recreational Use}

Goal: To maximize the recreational benefits and enjoyment to Albertans from the pronghorn antelope resource through provision of a variety of types and amounts of recreational opportunities.

\section{Subgoals:}

1. To provide the maximum opportunity to hunt trophy antelope in a quality hunting situation where hunter densities will not exceed one per $5 \mathrm{~km}^{2}$ and there will be a chance to shoot a large trophy buck.

2. To provide the maximum opportunity to hunt non-trophy antelope.

3. To provide an opportunity to hunt antelope with a bow and arrow.

4. To provide the maximum opportunity for directly related nonconsumptive wildlife activities (viewing, photographing, studying, improving habitat for) to all Albertans.

Objectives:

a) Provide the opportunity for 2270 residents to hunt 4540 days and harvest 1590 trophy antelope with hunter success rate of 70 percent.

b) Provide the opportunity for 2075 residents to hunt 4150 days and harvest 1660 non-trophy antelope with a hunter success rate of 80 percent.

c) Provide the opportunity for 350 bow hunters to hunt 1370 days and harvest 90 antelope ( 80 trophy, 10 non-trophy) with a hunter success rate of 25 percent.

d) Provide the opportunity for 1.5 million Albertans to spend 80 million days on directly related nonconsumptive wildlife activities (objectives for nonconsumptive use are not developed by species so antelope is just one of the many wildlife species involved). 
Goal: To provide the opportunity for Albertans to benefit economically from the commercial use of the antelope resource.

Objective:

Provide an opportunity for outfitters, guides and other Albertans providing goods and services to benefit economically from non-resident use of the antelope resource. The number of antelope licences allocated to non-resident hunting, will be determined by the Non-resident Big Game Outfitting and Guiding Policy.

\subsubsection{Science and Education}

Goal: To promote and encourage scientific and educational programs that will enhance the knowledge of the biology of pronghorns and their socioeconomic benefits to Albertans.

\subsubsection{Protection of Property}

Goal: To minimize property damage caused by antelope.

Objective:

Keep the annual damage by antelope below $\$ 25000$.

\subsubsection{Population and Habitat}

Goal: To ensure that pronghorn antelope populations and habitat are managed to meet the resource requirements of the recreational and economic goals and objectives.

Objectives:

a) Maintain a winter pronghorn population of 15500 animals 
which will provide a fall population of 18910 animals with a harvestable surplus of 1740 trophy antelope and 1670 non-trophy antelope annually (Table 12). Annual numbers may fluctuate above and below these goals because of environmental factors such as winter weather.

b) Maintain eight Antelope Management Areas and manage the pronghorn herds on the basis of 12 recognized winter ranges (Figure 7 ) and any additional winter ranges that may be discovered.

c) Maintain $25900 \mathrm{~km}^{2}$ of natural grass prairie summer range to support the pre-hunting season population of 18910 pronghorns and $3290 \mathrm{~km}^{2}$ of winter range to support the winter population of 15500 .

\subsection{Management Strategies}

\subsubsection{Population Management}

The pronghorn antelope population will be managed, through a variety of strategies, to provide recreational hunting opportunities, an opportunity for widespread nonconsumptive enjoyment and an opportunity for Albertans to benefit from guiding and servicing users (both hunters and general tourists).

\subsubsection{Trophy Antelope Harvest Regime}

The harvest regimes are derived from the population model presented in Appendix VI and are based on many assumptions that require further testing in the future. Males will be harvested to provide a maximum sustained yield of trophy bucks (including some bucks with larger horns) by maintaining the population at the postseason goal (Table 11) and by maintaining a postseason sex ratio of 30 bucks: 100 does. This represents an average male harvest goal of 9 percent of the preseason population (or 43 percent of the number of preseason males). The current definition for trophy, which is any male pronghorn antelope with horns $12.6 \mathrm{~cm}$ ( 5 in.) or more in length, will be maintained. 


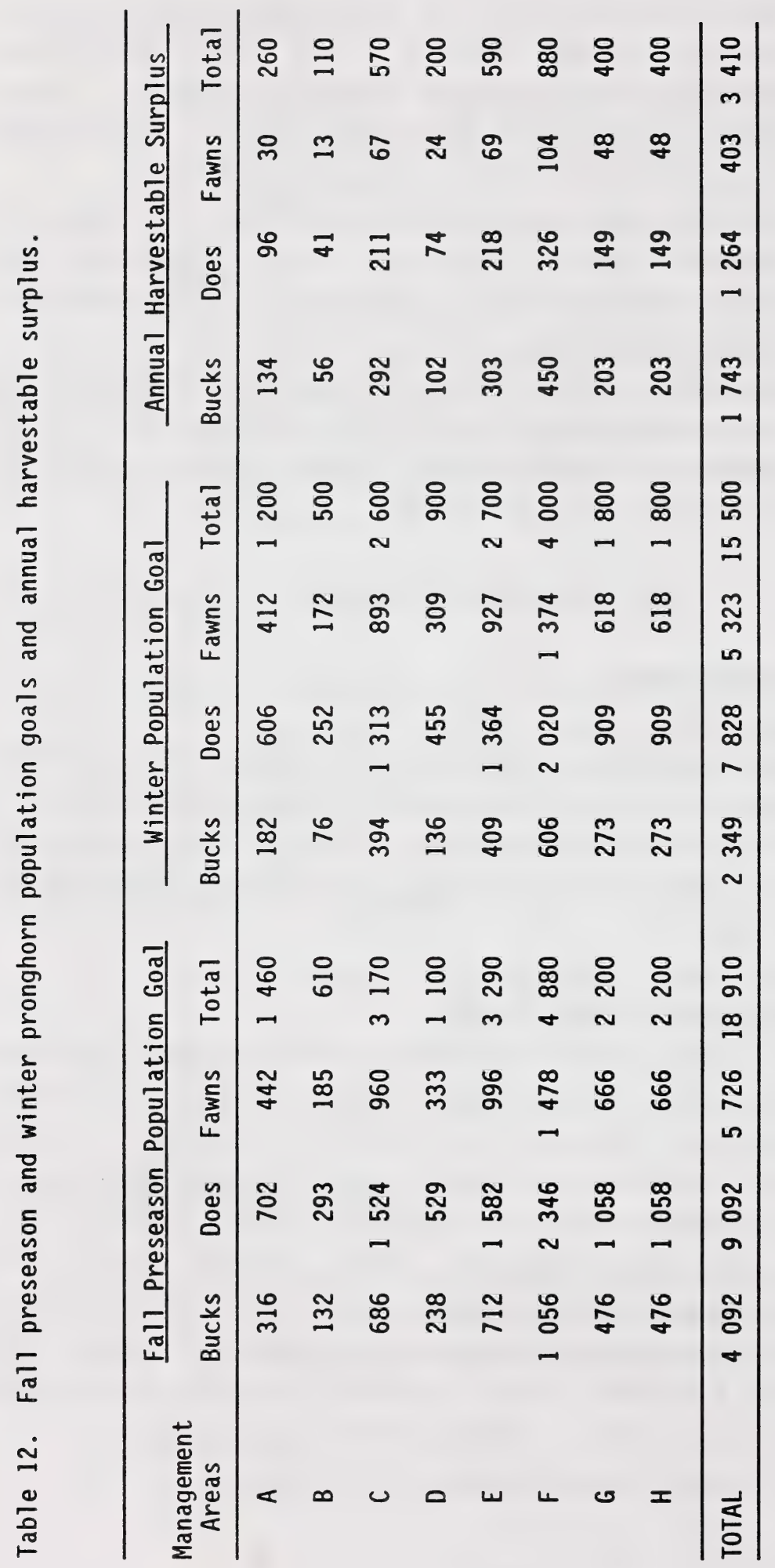




\subsubsection{Non-Trophy Antelope Harvest Regime}

Female and fawns will be harvested to provide a maximum sustained yield of non-trophy antelope by maintaining the population at the postseason goal (Table 11) and by maintaining a postseason sex ratio of 30 bucks: 100 does. This represents an average non-trophy harvest goal of 9 percent of the preseason population (or 14 percent of the number of preseason does and 7 percent of the number of preseason fawns). The current definition for non-trophy, which is any pronghorn with horns 7.6 $\mathrm{cm}$ ( 3 in.) or less in length, will be maintained.

\subsubsection{Harvest Rate Adjustments}

The trophy and non-trophy harvest goals will be adjusted upward or downward to meet the postseason population goal. Upward adjustments will be limited by the maximum allowable hunter density in each management area (Table 13) unless additional time periods are provided. Maximum allowable hunter densities are designed to maintain a quality hunting experience and minimize disturbance to landowners. Downward adjustments in the harvest rate will be 2.25 percent for every 10 percent the preseason population is below the goal of 18910 . This means there will be a non-trophy season closure when the preseason population is 11346 ( 60 percent of the preseason goal) or below. The trophy harvest will be adjusted downward to maintain the 30 bucks: 100 does postseason sex ratio. This would result in a trophy harvest rate of 9 percent of the preseason population when the preseason population is at 60 percent of the preseason goal. This 9 percent rate will continue to be used for trophy antelope until the preseason population reaches 3000 at which time the trophy season will be closed.

\subsubsection{Licencing and Use Management}

\subsubsection{Recreational Hunting of Trophy Antelope}

Resident hunters will be licenced using a limited entry draw. The number of resident Trophy Antelope Special Licences will be determined by Antelope Hunting Area by dividing the allowable harvest of trophy antelope by the mean hunter success rate for the previous three years. Hunters successful in the Trophy Antelope Special Licence draw will not 
Table 13. Guidelines for the maximum numbers of pronghorn antelope hunters in the field during a hunting season.

Antelope Management Area

\begin{tabular}{cc} 
Area & of Hunters \\
\hline A & 300 \\
B & 175 \\
C & 600 \\
D & 250 \\
E & 530 \\
F & 600 \\
G & 750 \\
H & 750 \\
\hline Total & 3955 \\
\hline
\end{tabular}


be eligible to apply for this licence in the following two calendar years.

Non-resident hunters must be accompanied by a guide and will be licenced using a limited-entry draw or special licence available through an outfitter-guide. Non-resident hunters obtaining a Trophy Antelope Special Licence will not be eligible to obtain or apply for this licence in the following two calendar years.

All trophy hunters - If the number of applicants for Trophy Antelope Special Licences exceeds the number of licences available by 2.5 times for two consecutive years, longer wait-out periods for applicants will be considered.

\subsubsection{Recreational Hunting of Non-trophy Antelope}

Non-trophy Antelope Special Licences will be available only to residents and will be issued using a limited-entry draw. The number of licences will be determined by management area by dividing the allowable harvest of non-trophy antelope by the mean hunter success rate for the previous three years.

\subsubsection{Antelope Archery Hunting}

Resident hunters will be licenced using a limited-entry draw. There will be 350 licences available. If the number of applicants for this licence exceeds the number available by more than 2.5 times for two consecutive years, a wait-out period for applicants will be considered.

Non-resident hunters must be accompanied by a guide and a limited number of licences will be available through an outfitter-guide.

\subsubsection{Antelope Licence Combinations}

Hunters may apply for a Non-trophy Antelope Special Licence and an Antelope Archery Special Licence every year. Hunters meeting the application eligibility requirements for the Trophy Antelope Special Licence may apply for all three licences, but may possess only one of these licences. The Antelope Archery Special Licence draw will be conducted first. Those hunters drawn for an Antelope Archery Special Licence will not be included in the Trophy or Non-trophy Antelope Special Licence draws. The Trophy Antelope Special Licence Draw will be 
conducted second. Those hunters drawn for a Trophy Antelope Special Licence will not be included in the Non-trophy Antelope Special Licence Draw. The non-trophy draw will be conducted last. One tag for one animal will normally be issued with a Non-trophy Antelope Special Licence. If there is a significant undersubscription in the non-trophy draw or a need to reduce the herd for management purposes, the issue of multiple tags (for more than one animal) with each licence may be considered to achieve the harvest goal.

\subsubsection{Guiding and Outfitting}

Non-residents are required to be accompanied by a licenced guide to hunt pronghorn antelope in Alberta. The number of trophy antelope licences allocated to non-resident use will be determined by the Non-Resident Big Game Outfitting and Guiding Policy. Outfitters may also guide residents and non-residents on nonconsumptive outings to observe and photograph antelope.

\subsubsection{Nonconsumptive Use}

The entire pronghorn antelope population is available for nonconsumptive use at any time even though some animals have been allocated for consumptive use and will be removed during the hunting season. The main strategy therefore is to enhance the opportunity for the public to interact with the antelope herd. This will be accomplished by doing the following:
a) maintaining a widely distributed and viewable pronghorn antelope population,

b) providing written material on the natural history and management challenges for antelope in Alberta,

c) enhancing public knowledge of specific dates, times and places where pronghorns can be viewed by providing an antelope viewing guide (to be incorporated with a number of other wildlife species in a more comprehensive guide),

d) enlisting the assistance of the public in pronghorn antelope management programs such as habitat enhancement, damage prevention and population inventory and more general programs such as Use Respect and Outdoor Observer. 


\subsubsection{Hunting Seasons}

Hunting seasons will occur during the month of October, after the majority of the rut is completed and before the onset of male horn sheath loss in early November. The season will be one to two weeks in length with trophy seasons normally opening before non-trophy seasons. An archery-only time period will normally precede the general season. Season length and bag limits are not sufficient to control the harvest of pronghorn antelope so a special licence draw must be used. This limits the number of hunters and controls the harvest, maintains a reasonable quality hunt by controlling hunter density and minimizes landowner disturbance.

\subsubsection{Hunter Effort and Success}

Hunter success depends on how many animals there are in a given area, how available the animals are (vehicle access, terrain, and permission to hunt) and the timing and length of the season. Pronghorn antelope populations and seasons will be managed to provide an average of two days effort per hunter per year with an expected harvest success rate of 70 percent for trophy antelope and 80 percent for non-trophy antelope. Hunter effort and success will be monitored annually using a telephone harvest questionnaire and periodic collections of antelope lower jaws.

\subsubsection{Public Education and Information}

\subsubsection{Conservation Education}

The Alberta Conservation and Hunter Education program should continue to address its broad spectrum of topics such as user ethics, wildlife identification and management, firearm use and safety, field hunting and game handling techniques, and survival/first aid techniques. When dealing with pronghorn antelope, the emphasis should be on firearm safety, respect for private property, ethical hunting techniques, the humane kill of the animal, the proper care and handling of the carcass, and summary of the management goals, objectives and strategies for 
pronghorn antelope in Alberta. The latter will require an expansion of the current "wildlife management" section to include the species level. Ongoing programs such as Use Respect and Outdoor Observer which provide an annual emphasis on certain aspects of the conservation education program should be continued. An annual summary of the current year's hunter harvest and effort should be available to the public.

\subsubsection{Habitat Management}

Habitat sufficient to meet the provincial and local population goals will be provided as a result of both retention programs and development programs on private and public land. Development programs, which increase the carrying capacity of habitat, may add new habitat or mitigate the loss of habitat that was not protected under the retention program.

\subsubsection{Habitat Retention}

The steps involved in a habitat retention program are as follows: Inventory - Habitat inventory and habitat retention goals must be established for each Wildlife Management Unit. Inventory will be covered in Section 3.3.10.1. Habitat retention goals by Antelope Management Area are outlined in Table 14. Specific locations and areas of known winter ranges are outlined in Figure 7 and Table 8.

Integration - Habitat retention goals for pronghorn antelope must be integrated with other wildlife species and with other uses of the land base. Integration is accomplished through participation in regional and local planning on private land (e.g., Regional Planning Commission Plans and local Municipality or Special Areas Land Use Plans and Bylaws) and public land (e.g., Integrated Resource Plans and River Basin Plans). Application of Retention Goals - Specific retention goals must be applied to small parcels of both private and public land.

The next level of input and integration on private land must occur through land use $\mathrm{plans}$ and agreements with individual landowners. The agreements will recognize the landowner for retaining important pronghorn antelope habitat and may provide some form of reward for doing so. If Class 1 or 2 pronghorn habitat (based on a four-class habitat 
Table 14. Habitat goals to meet the 1999 population goals.

\begin{tabular}{|c|c|c|c|c|c|}
\hline \multirow{2}{*}{$\begin{array}{l}\text { Antelope } \\
\text { Management } \\
\text { Area }\end{array}$} & \multirow{2}{*}{$\begin{array}{l}1999 \text { Summer } \\
\text { Population } \\
\text { Goal }\end{array}$} & \multirow{2}{*}{\multicolumn{2}{|c|}{$\begin{array}{l}1999 \text { Winter } \\
\text { Population } \\
\text { Goal }\end{array}$}} & \multicolumn{2}{|c|}{$\begin{array}{c}\text { Square Kilometres of } \\
\text { Habitat Required }\end{array}$} \\
\hline & & & & $\begin{array}{l}\text { Summer } \\
\text { Range }^{\text {a }}\end{array}$ & $\begin{array}{l}\text { Winter } \\
\text { Rangeb }\end{array}$ \\
\hline A & 1460 & 1200 & 1040 & 2000 & 260 \\
\hline B & 610 & 500 & 430 & 840 & 110 \\
\hline C & 3170 & 2600 & 2250 & 4340 & 550 \\
\hline D & 1100 & 900 & 780 & 1510 & 190 \\
\hline$E$ & 3290 & 2700 & 2340 & 4510 & 570 \\
\hline$F$ & 4880 & 4000 & 3460 & 6680 & 850 \\
\hline G & 2200 & 1800 & 1560 & 3010 & 380 \\
\hline H & 2200 & 1800 & 1560 & 3010 & 380 \\
\hline Total & 18910 & $15500^{C}$ & $13 \quad 420$ & 25900 & 3290 \\
\hline
\end{tabular}

aIt was assumed that the average density on summer range is 0.73 pronghorn antelope per $\mathrm{km}^{2}$ (based on aerial survey data). The word "range" refers to native grass prairie and does not include cultivated crops and hay. Area has been rounded to the nearest ten.

bIt was assumed that the average density on winter range is 4.7 pronghorn antelope per $\mathrm{km}^{2}$ (based on current use of known winter range). The amount of winter range is based on the December population goal. The word "range" refers to native grass prairie and does not include cultivated crops and hay. Area has been rounded to the nearest ten.

CThis total does not include the C.F.B. Suffield herd which would number around 2000; there is limited control over this herd because there is no hunting harvest. An additional $425 \mathrm{~km}^{2}$ of winter range, currently present in Suffield would be required to winter these animals. 
capability system with Class 1 being best) on private land is threatened and cannot be protected through agreement (i.e., the landowner does not want to participate in the retention program and has indicated a desire to remove the habitat) and there is little chance of mitigating the loss, then purchase should be considered.

Integration of habitat retention goals on public land occurs through the government 1 and use referral process. Referrals may result in a standard condition to protect habitat or individual recommendations for each referral regarding habitat retention during land use activities such as, agricultural expansion and intensification, $0 i 1$ and gas exploration and development, transmission line and transportation corridor development, recreation development, mining exploration and development, thermal power generation development, development of dams for flow regulation and hydropower, and urban expansion. Guidelines to maintain quality pronghorn antelope habitat generally involve restrictions on the type, size, shape and level of use, restrictions on the location or time period of use, controls on the type of public access to the development site and suggestions for reclamation. If the important habitat for pronghorn antelope has not been identified in planning documents used by referral agencies, then such habitat should be flagged with an appropriate Fish and Wildlife reservation. If referrals are not successful in retaining habitat, then the loss should be mitigated via habitat enhancement in another location.

\subsubsection{Habitat Enhancement}

Habitat enhancement--increasing the carrying capacity of a unit of land--may take place on private or public land but the latter would have priority. The highest priority for enhancement of pronghorn antelope habitat should be parcels of public land in areas where habitat loss is occurring on private 1 and and where crop damage is severe on private land, particularly on winter ranges where large numbers of animals concentrate in small areas. Enhancement techniques to be considered would be managed livestock grazing to encourage desirable plant species composition, controlled burning and/or chaining to improve plant species diversity and quality of winter range, planting of important winter range food species and cooperative planting of cereal crops (e.g., 
winter wheat or fall rye) to act as lure crops to reduce surrounding crop damage and provide a high quality fall/winter/spring food source. Site-specific plans will have to be developed by regional wildlife and habitat staff.

\subsubsection{Predator Management}

Coyotes and bobcats have been identified as causing significant mortality in pronghorn antelope fawns (Barrett 1982). Both predators are currently harvested during annual trapping seasons and damage control on private land. Since the pronghorn antelope population continues to maintain a high level of productivity and is within established goals over most of its range, no widespread predator management program is proposed at this time.

\subsubsection{Other Mortality Factors}

\subsubsection{Winter Mortality}

The length of winter, depth of snow and number of days with very cold temperatures have a profound effect on survival and spring fawn production. These climatic features will be monitored to produce a winter severity index. If a significant winter die-off is predicted, a winter feeding program may be considered for pronghorn antelope. Further development and testing of food rations and techniques such as those used by Murray (1986) will be necessary before extensive feeding takes place.

\subsubsection{Parasites and Diseases}

Parasites and diseases are not known to cause significant mortality in Alberta pronghorn antelope, but monitoring should be continued by examining carcasses submitted by hunters, landowners and district and regional staff. Staff should continue to seek the assistance of university and Provincial Veterinary Laboratory staff who specialize in the identification and diagnosis of parasites and diseases of wildlife. 


\subsubsection{Accidental Deaths}

Accidental deaths may be locally significant, particularly those associated with vehicle collisions during winters when deep snow forces antelope onto roads and railway tracks. There are also many vehicle collision deaths through the rest of the year, but current knowledge indicates those deaths are widely dispersed, making fencing and/or overpasses impractical. Vehicle collision deaths should be monitored and winter solutions such as plowed travel corridors and lure sites should be considered where animals are concentrated and significant mortality is occurring or anticipated. Antelope often get caught up in fences so landowners and government agencies replacing fences or building new fences should be encouraged to use a smooth bottom strand of wire $41 \mathrm{~cm}$ above the ground to allow safe passage of antelope. Irrigation canal upgrading should be monitored because antelope are unable to cross the new, smooth concrete canals. If accidental drowning becomes significant, fencing and overpasses should be considered.

\subsubsection{Illegal Harvest}

The illegal harvest is likely quite small for pronghorn antelope, probably related to the open terrain where they are highly visible and because they have a small carcass weight. Current levels of enforcement should be maintained, particularly during the hunting season, to ensure that the illegal harvest is kept low and the hunt is conducted in an ethical manner.

\subsubsection{Protection of Private Property}

Damage by pronghorn antelope is very limited and generally involves fall-planted cereal crops such as winter wheat or fall rye. Complaints will be handled through the district offices. Landowners will be provided with assistance in the prevention and control of the damage.

Prevention would involve scaring devices which provide some shortterm relief. In locations of chronic damage, on traditional winter range, prevention may include lure crops or intercept feeding sites if investigation shows these are effective techniques.

Control involves the removal of animals. Hunting will be used to 
maintain herds within the population goal for a particular area. Other control methods such as trapping and relocating or the issuing of kill permits are either too expensive, impractical, or unnecessary and would not normally be considered.

Although compensation for damage is an alternative that requires further investigation, it is very difficult to determine the degree of damage, for example in an early-fall harvested crop, that can be attributed to pronghorn activity during the previous late fall or winter. Range improvements that benefit both landowners and antelope will be considered as one alternative to compensation in chronic damage locations.

\subsubsection{Population and Habitat Inventory}

Population inventory provides the information on distribution, density, age/sex ratios, productivity and condition of animals, which is essential to meet the resource management and allocation goals for this species. Habitat inventory provides the necessary information on food and cover, which are two of the major factors influencing distribution, density, productivity and condition of animals in the population.

\subsubsection{Population Inventory}

Population inventory involves direct methods where pronghorn antelope are actually observed (e.g., aerial survey) and indirect methods (e.g., jaw collections, harvest questionnaires, range condition surveys, incidence of damage complaints). Direct methods provide information on distribution, density, age/sex ratios and productivity but the information is often limited or incomplete. Indirect methods provide additional information on distribution, density, age distribution within male and female cohorts, and mean age of survival. The techniques used for antelope population inventory will be as follows:

Aerial Surveys - Aerial surveys are the only practical direct population inventory method because of the large geographic area, widely dispersed pronghorn antelope herd, limited manpower and suitability of the habitat to this type of survey. Aerial surveys will be conducted annually in 
all the Antelope Management Areas according to the methodology laid out in the Provincial Survey Format (Appendix IV). This is different than the current survey format (half the areas surveyed each year), but annual coverage is necessary because of differences in distribution and productivity that occur between management areas on an annual basis.

Jaw Collection - Jaw collections should be made periodically to monitor the age distribution in the herd and the percentage of fawns in the non-trophy harvest.

Harvest Questionnaires - The telephone questionnaire determining hunter effort and pronghorn antelope harvest should be conducted for all Antelope Management Areas annually, sampling 25 percent of the licenced hunters.

Range Condition Surveys (see Habitat Inventory, Section 3.3.10.2)

Damage Complaints - Damage complaints should be monitored as part of the annual damage prevention program.

\subsubsection{Habitat Inventory}

Habitat inventory provides a basis for population inventory, a benchmark to set population goals and a local focus for habitat retention and enhancement programs. The following two types of habitat inventory should occur:

General Assessment - A general assessment, focusing at the $2.6 \mathrm{~km}^{2}$ (1 sq. mi.) level, should be conducted every 10 years (unless major land use changes warrant a more frequent review). The purpose of this assessment will be to determine the extent of pronghorn antelope summer range and note any changes that might require new habitat retention/enhancement programs.

Winter Range Assessment - Better delineation of winter range, based on antelope use and/or distribution, should be an ongoing annual process. A detailed assessment of winter range, focusing at the $0.7 \mathrm{~km}^{2}(1 / 4$ section) level, should be conducted every five years (unless major 1 and use changes warrant a more frequent review). The purpose of this assessment will be to determine the condition of the range and any loss of habitat and to develop new habitat retention/enhancement strategies as required. 


\subsubsection{Summary of Goals and Strategies}

The primary goal is to manage for a winter population of 15500 and a summer population of 18910 pronghorn antelope, which will provide a variety of recreational, scientific and commercial opportunities with a minimum of damage to private property.

Recreational opportunities will include both hunting and nonconsumptive use. Resident hunters will be provided with 10940 recreation days and an average annual harvest of 1670 trophy antelope and 1670 non-trophy antelope with an anticipated hunter success rate of 70 percent for trophy and 80 percent for non-trophy. Hunters will be licenced using a special licence issued through a draw or outfitter-guide allocation. Hunters successful in receiving a Trophy Antelope Special Licence through the draw will not be eligible to apply for that licence during the following two calendar years. Hunting seasons will occur during the months of September and October. A specific number of nonconsumptive user days has not been identified, but efforts will be made to increase public awareness of the resource and contribute to a written guide indicating the best times and locations to view pronghorn antelope.

Scientific study of the resource will be encouraged, particularly in the area of the impact of changing land uses and winter weather on the biology and behavior of pronghorn antelope.

Commercial opportunities will involve the outfitting and guiding of non-resident hunters and tourists.

Identification and protection of important pronghorn antelope range, particularly winter range, will be a high priority. Development of suitable habitat enhancement techniques (for Alberta), to mitigate ongoing habitat losses, will also be a priority.

Mortality factors other than recreational hunting such as winter starvation, parasites and disease, predation, accidental deaths, and illegal harvest will be addressed to varying degrees. Techniques to alleviate high levels of mortality during severe winters will be tested. Parasites and diseases will be monitored during routine necropsies for animals that die accidentally or whose cause of death is unknown. There will be no attempt to control predators beyond current levels of 
resident trapper harvest and agricultural pest control. Antelope deaths resulting from vehicle collisions, irrigation canals and barbed-wire fences will be monitored and appropriate steps taken if they increase to significant levels. Illegal harvest will be monitored and current high levels of enforcement during the hunting season will be maintained.

Damage to private property will be minimized through prevention and control programs. Prevention will include both scaring efforts for short-term relief and the provision of alternate feeding sites (e.g., lure crops) for longer term relief in chronic damage situations. Hunting will be used to maintain herds at proposed goals and cooperative range management programs will be pursued to provide benefits to both landowners and pronghorn antelope. Compensation for damage will be evaluated as a management measure to determine its feasibility in antelope damage situations. 


\subsection{MANAGEMENT PLAN APPLICATION}

\subsection{Provincial Summary}

The major management challenges for pronghorn antelope are to maintain a stable antelope population to maximize recreational opportunity, to retain or enhance sufficient habitat to meet population goals, to maintain recreational use within levels acceptable to both users and 1 andowners and to minimize damage to private property.

The summer population goal is 18910 , which requires $25900 \mathrm{~km}^{2}$ of summer range (native grass prairie) and the early winter goal is 15500 , which requires $3300 \mathrm{~km}^{2}$ of winter range (native grass-sagebrush). To maintain the antelope populations at a sustained harvest level and provide an acceptable quality of hunting experience, it is necessary to control the number of hunters and their distribution using a special licence draw. Wait-out periods and limits on hunter licence combinations will help ensure that everybody has a fair chance to hunt. To increase nonconsumptive use, opportunity guides and viewing sites must be provided, but care must be taken to minimize disturbance of landowners and antelope. Habitat retention and enhancement programs on both private and public land must be pursued to ensure maintenance of populations at identified goal levels. Cooperative range management, benefiting both livestock and antelope, is the desired goal. Efforts must also continue to prevent crop damage and to evaluate the feasibility of expanded damage compensation in antelope damage situations.

\subsection{Regional Perspective}

\subsubsection{Southern Region}

The Southern Region (Figure 9) has 77 percent of the provincial 


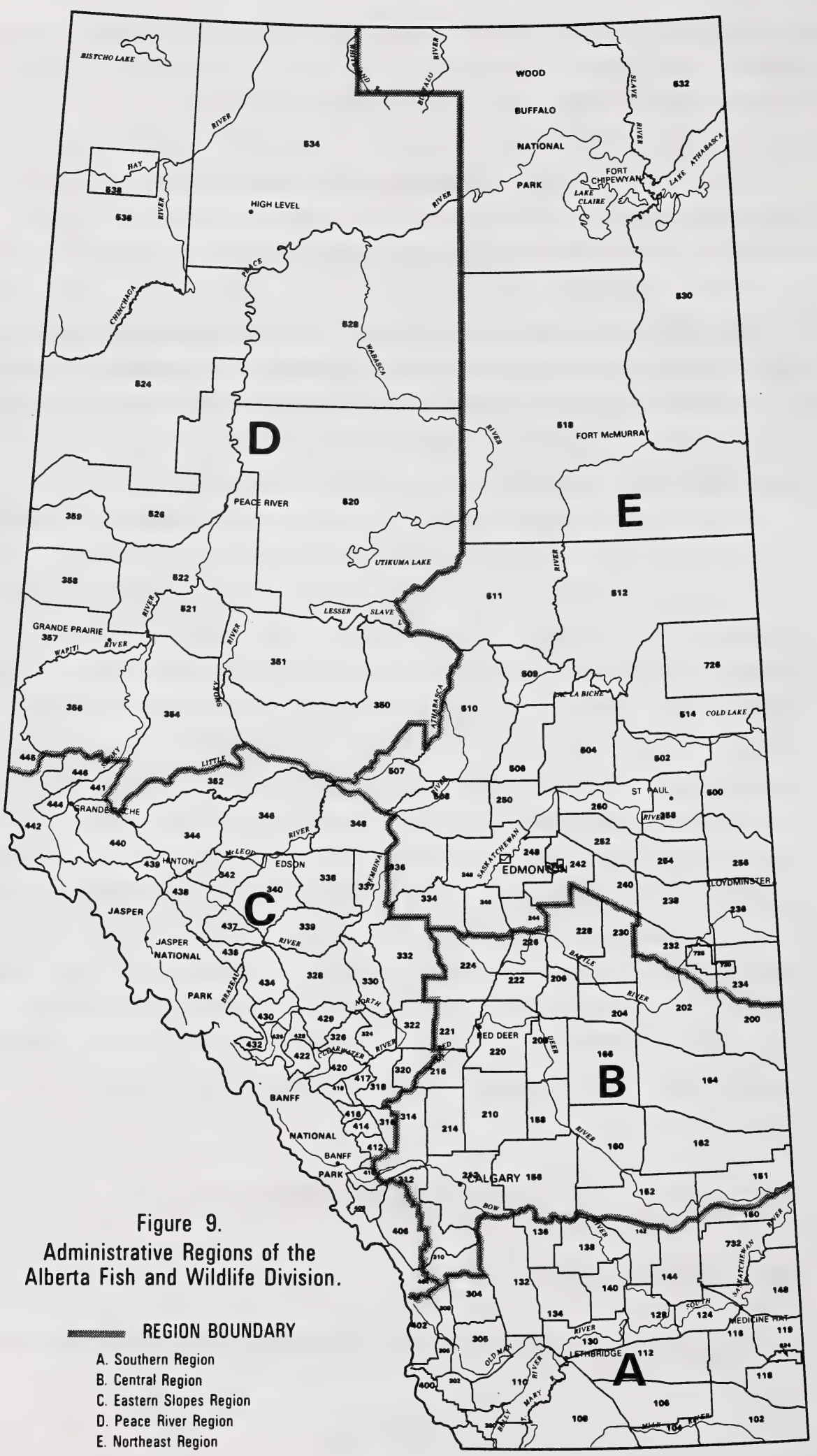


antelope population, demand for antelope hunting is very high and the landscape is dominated by agricultural land that is either privately owned property or leased public land. Population goals are 14510 antelope in summer, 11900 in early winter (December) and 10300 in late winter (April). Management emphasis will be directed towards doing the following:

1. Identifying specific population and habitat retention and enhancement goals for all Wildlife Management Units (WMUs) within the regional antelope range and developing strategies to achieve these goals. Goals will have to be separated into summer and winter periods.

2. Improving the knowledge of antelope movements and use of different seasonal ranges with particular emphasis on better delineation of winter range and its relationship to summer ranges of the different herds.

3. Monitoring populations and habitat to determine the success in maintaining the population and a suitable habitat base to support it.

4. Recommending annual hunting permit allocations and assessing the suitability of the harvest regime for the current population trend and status, as well as for the hunter demand.

5. Identifying potential viewing sites and providing information to the public regarding antelope biology and distribution.

6. Cooperating with domestic livestock range managers to develop range management programs that benefit both antelope and domestic livestock.

7. Improving the prevention of localized pronghorn damage on private land.

8. Exploring ways to incorporate C.F.B. Suffield into the harvest system and overall management of the pronghorn antelope herd in the region.

\subsubsection{Central Region}

The Central Region (Figure 9) has 23 percent of the provincial antelope population, demand for antelope hunting is very high and the 
landscape is dominated by agricultural land that is either privately owned property or leased public land. Population goals are 4400 antelope in summer, 3600 in early winter (December) and 3120 in late winter. Management emphasis will be directed towards doing the following:

1. Identifying specific population and habitat retention and enhancement goals for all WMUs within the regional antelope range and developing strategies to achieve these goals. Goals will have to be separated into summer and winter periods.

2. Improving the knowledge of antelope movements and use of different seasonal ranges with particular emphasis on better delineation of winter range and its relationship to summer ranges of the different herds.

3. Monitoring populations and habitat to determine the success in maintaining the population and a suitable habitat base to support it.

4. Recommending annual hunting permit allocations and assessing the suitability of the harvest regime for the current population trend and status, as well as for the hunter demand.

5. Identifying potential viewing sites and providing information to the public regarding antelope biology and distribution.

6. Cooperating with domestic livestock range managers to develop range management programs that benefit both antelope and domestic livestock.

7. Improving the prevention of localized pronghorn damage on private 1 and. 


\subsection{REFERENCES CITED}

Autenrieth, R. 1978. Guidelines for the management of pronghorn antelope. Proc. Bienn. Pronghorn Antelope Workshop 8:473-526.

Autenrieth, R. 1980. Vulnerability of pronghorn fawns to predation. Abstract. Proc. Bienn. Pronghorn Antelope Workshop 9:77-79.

Banfield, A. W. F. 1974. The Mammals of Canada. University of Toronto Press, Toronto, Ontario. $438 \mathrm{pp}$.

Barrett, M.W. 1974. Importance, utilization and quality of Artemesia cana on pronghorn winter ranges in Alberta. Proc. Bienn. Pronghorn Antelope Workshop 6:26-57.

1978. Pronghorn fawn mortality in Alberta. Proc. Bienn. Pronghorn Antelope Workshop 8:429-444.

1981. Environmental characteristics and functional significance of pronghorn fawn bedding sites in Alberta. J. Wildl. Manage. 45:120-131.

1982. Ranges, habitat and mortality of pronghorns at the northern limits of their range. Ph.D. Thesis. University of Alberta, Edmonton, Alberta. 223 pp.

and H. Vriend. 1980. Management implications of the seasonal distribution of pronghorns and land use practices in Alberta Proc. Bienn. Pronghorn Antelope Workshop 9:196-214.

Bayless, S. R. 1969. Winter food habits, range use, and home range of antelope in Montana. J. Wildl. Manage. 33:538-551.

Beale, D. M., and A. D. Smith. 1970. Forage use, water consumption and productivity of pronghorn antelope in western Utah. J. Wildl. Manage. $34: 570-582$.

1973. Mortality of pronghorn antelope fawns in western Utah. J. Wildl. Manage. 37:343-352.

Bodie, W. L. 1978. Pronghorn fawn mortality in the upper Pahsuneroi River drainage of central Idaho. Proc. Bienn. Pronghorn Antelope Workshop 8:417-428.

Chalmers, G. A., H. N. Vance, and G. J. Mitchell. 1964. An outbreak of epizootic hemorrhagic disease in wild ungulates in Alberta. Wildl. Dis. $42: 1-6$. 
Clark, J. 1985. Classification of antelope range by wildlife management units and antelope hunting areas. Unpublished Report. Alberta Fish and Wildlife Division, Edmonton, Alberta. 59 pp.

Cook, A. R. 1981. Antelope aerial survey and population analysis. July 20-28, 1981. Unpublished Report. Alberta Fish and Wildlife Division, Edmonton, Alberta. $162 \mathrm{pp}$.

Filion, F. L., E. DuWors, A. Jacquemot, P. Bouchard, P. Boxall, P. A. Gray and R. Reid. 1989. The importance of wildlife to Canadians in 1987: highlights of a national survey. Canadian Wildlife Service, Environment Canada, Ottawa, Ontario. $45 \mathrm{pp}$.

Fish and Wildlife Division. 1982. Fish and Wildlife Policy for Alberta. Dept. of Energy and Natural Resources, Edmonton, Alberta. $24 \mathrm{pp}$.

1984. Status of the Fish and Wildlife Resource in Alberta. Dept. of Energy and Natural Resources, Edmonton, Alberta. 160 pp.

Glaholt, R. D. 1984. Availability of critical pronghorn antelope habitat in southern Alberta and its relation to land use. M. Envir. Design Thesis. University of Calgary, Calgary, Alberta. 190 pp.

Good, J. R., and J. A. Crawford. 1978. Factors influencing pronghorn use of playas in south central Oregon. Proc. Bienn. Pronghorn Antelope Workshop 8:182-205.

Gurba, J., and D. Neave. 1979. Problem wildlife management manual. Alberta Agriculture and Alberta Energy and Natural Resources, Edmonton, Alberta. $136 \mathrm{pp}$.

Haag, R. 1986. Recent changes in cultivated 1 ands within the pronghorn antelope range. Unpublished Report. Alberta Resource Evaluation and Planning Division, Edmonton, Alberta. 29 pp.

Kemp, G. A. 1983. Walsh Flats pronghorn winter range options for protection and management. Prepared by Prism Environmental Management Consultants for the Alberta Fish and Wildlife Division, Edmonton, Alberta. $60 \mathrm{pp}$.

Kitchen, D.W. 1974. Social behavior and ecology of the pronghorn. Wildife Monograph No. $38.96 \mathrm{pp}$.

A. Chap and B. W. O'Gara. 1982. Pronghorn. Pages 960-971. In J. America. The John's Hopkins University Press, Baltimore, Md.

Lothian, W. F. 1977. A History of Canada's National Parks. Vol. II. Parks Canada, Ottawa, Ontario. 85 pp. 
McCuaig, J. D., and E. W. Manning. 1982. Agricultural land use change in Canada: process and consequences. Land Use in Canada series, number 21. Supply and Services Canada, Ottawa, Ontario. 213 pp.

Mitchell, G. J. 1980. The Pronghorn Antelope in Alberta. University of Regina. Regina, Saskatchewan. 165 pp.

and S. Smoliak. 1971. Pronghorn antelope range characteristics and food habits in Alberta. J. Wildl. Manage. $35: 238-250$.

Murray, D. 1986. Antelope feeding trial project report - southern Alberta 1985/86. Unpublished Report. Alberta Fish and Wildlife Division, Edmonton, Alberta. 15 pp.

Neff, D. J., and N. G. Woolsey. 1980. Coyote predation on neonatal fawns on Anderson Mesa, Arizona. Proc. Bienn. Pronghorn Antelope Workshop 9:80-93.

Oakley, C. 1973. The effects of livestock fencing on antelope. Wyoming Wildlife $37(12): 26-29$.

Ord, G. 1818. Antilocapra Ord. J. De Physique, De Chimie, D'Historie Naturelle Et Des Arts. Paris, France. 87:149-151.

Pedocan Land Evaluation Ltd. 1984. Final Report - Preliminary wildlife habitat regions/subregions of Alberta. Prepared for Alberta Energy and Natural Resources, Fish and Wildlife Division, Edmonton, Alberta. $55 \mathrm{pp}$.

Phillips, W., D. DePape and L. Ewanyk. 1977a. A socioeconomic evaluation of the recreational use of fish and wildlife resources in Alberta with particular reference to the Athabasca oil sands area. Vol. IV. Nonconsumptive recreational use of fish and wildilife. $220 \mathrm{pp}$.

1977b. A socioeconomic evaluation of the recreational use of fish and wildlife resources in Alberta with particular reference to the Athabasca oil sands area. Vol. III. Recreational hunting. $252 \mathrm{pp}$.

Schmidt, J. L., and D. L. Gilbert, editors. 1978. Big game of North America. Wildlife Management Institute. Stackpole Books, Harrisburg. $494 \mathrm{pp}$.

Showers Corneli, P., B. L. Von Gunten Moran and B. O'Gara. 1984. Pronghorn mortality on the National Bison Range. Proc. Bienn. Pronghorn Antelope Workshop 11:41-48.

Tsukamoto, G. K. 1983. Pronghorn antelope species management plan. Nevada Dept. of Wildlife, Reno, Nevada. 59 pp.

Von Gunten, B. L. 1978. Pronghorn fawn mortality on the National Bison Range. Proc. Bienn. Pronghorn Antelope Workshop 8:394-416. 
Webb, R. 1963. Antelope aerial survey. Unpublished Report 63-017. Alberta Fish and Wildlife Division, Edmonton, Alberta. 9 pp.

Wishart, W. 1972. History and management of the pronghorn antelope in Alberta. Alberta Conservationist - Spring Issue: 20-22.

Wright, P. O., and S. A. Dow, Jr. 1962. Minimum breeding age in pronghorn antelope. J. Wildl. Manage. 26(1):100-101.

Yoakum, J. D. 1978a. Pronghorns. Pages 103-121. In J. L. Schmidt and D. L. Gilbert (editors). Big Game of North America. Stackpole Books, Harrisburg, P.A.

1978b. Managing rangelands for the American pron
antelope. Proc. Bienn. Pronghorn Antelope Workshop 8:321-336. 


\section{APPENDIX I.}

Estimated Pronghorn Antelope Populations, 1952-1989. 
Table A. Estimated antelope populations, 1952-1989.

\begin{tabular}{|c|c|c|c|c|}
\hline \multirow[b]{2}{*}{ Year } & \multicolumn{4}{|c|}{ Estimated Numbers of Antelope } \\
\hline & Region 1 & Region 2 & Suffield & Provincial \\
\hline 1952 & No Data & No Data & No Data & 4500 \\
\hline 1953 & No Data & No Data & No Data & 5000 \\
\hline 1954 & No Data & No Data & No Data & 8000 \\
\hline 1955 & No Data & No Data & No Data & 10000 \\
\hline 1956 & No Data & No Data & No Data & 15000 \\
\hline 1957 & No Data & No Data & No Data & 12500 \\
\hline 1958 & No Data & No Data & No Data & No Data \\
\hline 1959 & No Data & No Data & No Data & 11000 \\
\hline 1960 & No Data & No Data & No Data & 12200 \\
\hline 1961 & No Data & No Data & No Data & 13000 \\
\hline 1962 & No Data & No Data & No Data & 11500 \\
\hline 1963 & 11750 & 5860 & 1430 & 19040 \\
\hline 1964 & 14314 & 3863 & 2000 & 20177 \\
\hline 1965 & 9922 & 4309 & No Data & 14231 \\
\hline 1966 & 8546 & 3882 & No Data & 12428 \\
\hline 1967 & 6404 & 1843 & 1790 & 10037 \\
\hline 1968 & 4850 & 3150 & 1660 & 9660 \\
\hline 1969 & 3483 & 1517 & 1210 & 6210 \\
\hline 1970 & 7959 & 2071 & 1370 & 11400 \\
\hline 1971 & 7242 & 1342 & 840 & 9424 \\
\hline 1972 & 6766 & 2385 & 1260 & 10411 \\
\hline 1973 & 6736 & 2171 & 1720 & 10627 \\
\hline
\end{tabular}


Table A (continued)

\begin{tabular}{|c|c|c|c|c|}
\hline \multirow[b]{2}{*}{ Year } & \multicolumn{4}{|c|}{ Estimated Numbers of Antelope } \\
\hline & Region 1 & Region 2 & Suffield & Provincial \\
\hline 1974 & 6745 & 2610 & 1760 & 11115 \\
\hline 1975 & 6241 & 4136 & 1400 & 11777 \\
\hline 1976 & 8972 & 5751 & 2090 & 16813 \\
\hline 1977 & 9527 & 5756 & 2670 & 17953 \\
\hline 1978 & 6915 & 2574 & 1430 & 10919 \\
\hline 1979 & 7288 & 5492 & 2550 & 15330 \\
\hline 1980 & 8410 & 7067 & 3160 & 18637 \\
\hline 1981 & 9597 & 8960 & 2150 & 20707 \\
\hline 1982 & 13957 & 3605 & 3640 & 21202 \\
\hline 1983 & No Survey & & & \\
\hline 1984 & 21173 & 7898 & 3000 & 32071 \\
\hline 1985 & 15087 & 6067 & 3020 & 24174 \\
\hline 1986 & 15350 & 7450 & 2100 & 24900 \\
\hline 1987 & 17807 & 8402 & 2000 & 28209 \\
\hline 1988 & 14515 & 5592 & 3000 & 23107 \\
\hline 1989 & 14475 & 4839 & 3000 & 22314 \\
\hline
\end{tabular}

Region 1 - WMUs 102, 104, 106, 108, 112, 114, 116, 124, 126, 128, 138, $140,142,144$ and 148.

Region 2 - WMUs 150, 151, 152, 160, 162, 164.

Suffield - WMU 732.

The WMUs above, used to define Region 1, Region 2 and Suffield, are the current WMUs. However, these same geographic areas were used to compile the data for all years without regard to earlier WMU boundaries (which in many cases were different than current boundaries). 


\section{APPENDIX II.}

Estimated Pronghorn Antelope Harvest by Antelope Management Area, 1973-1989. Data for all years were adjusted to conform to the geographic boundaries of the current Antelope Management Areas. 


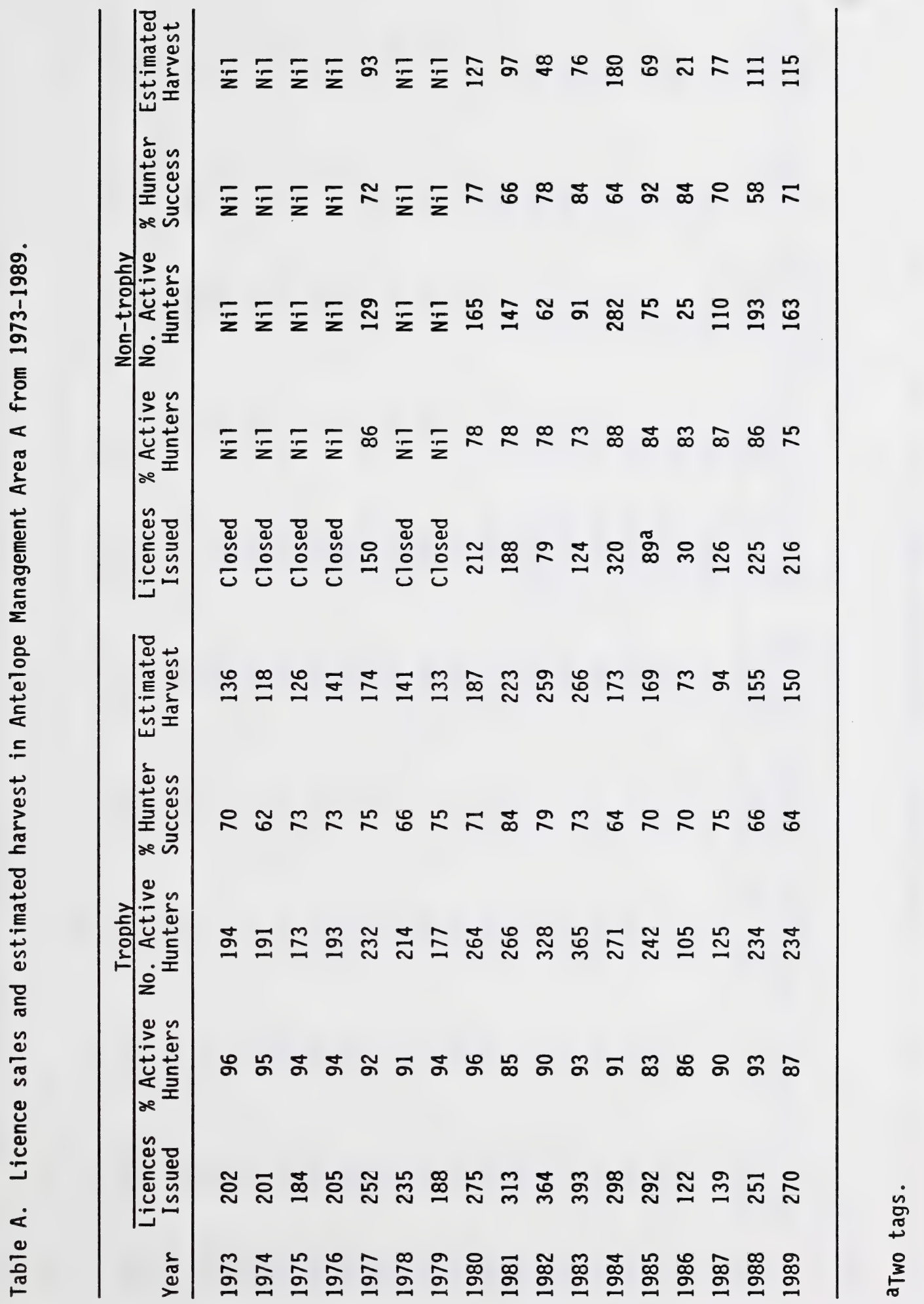




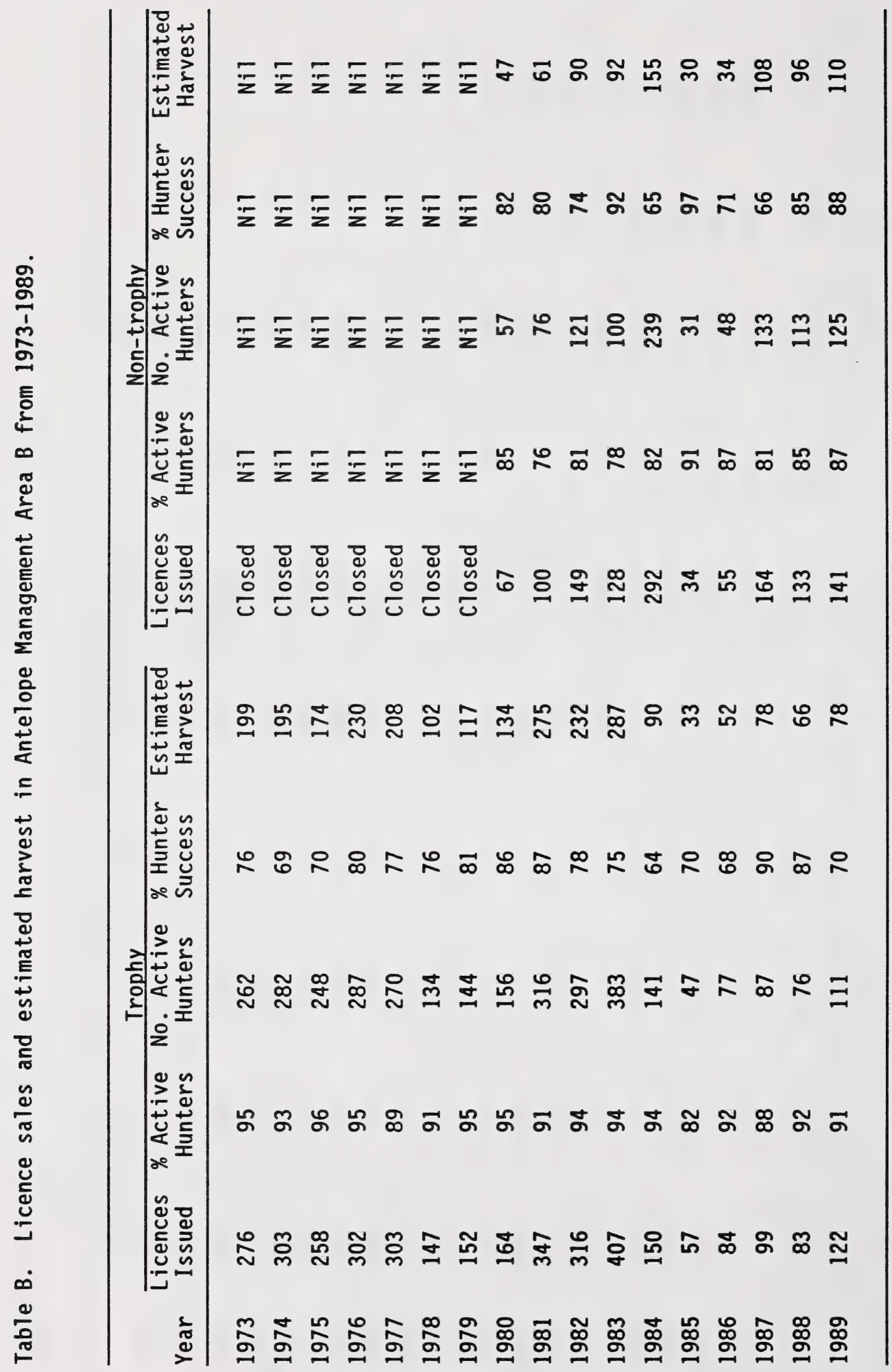




\begin{tabular}{|c|c|}
\hline 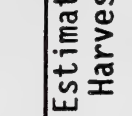 & 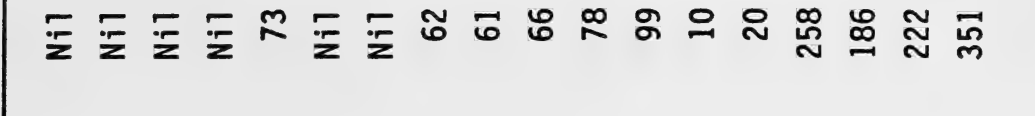 \\
\hline 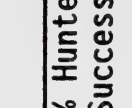 & 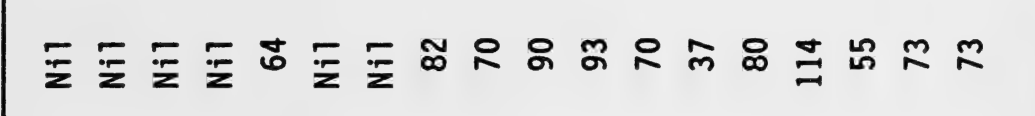 \\
\hline $\begin{array}{llllll} & \\
\end{array}$ & 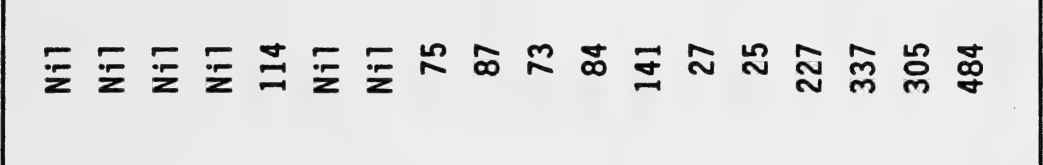 \\
\hline 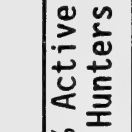 & 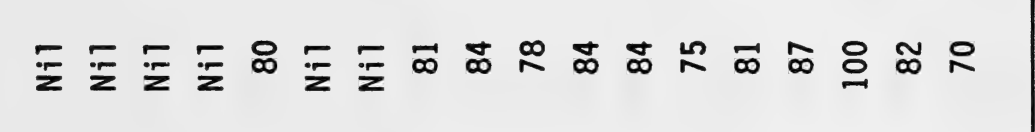 \\
\hline I\&z & 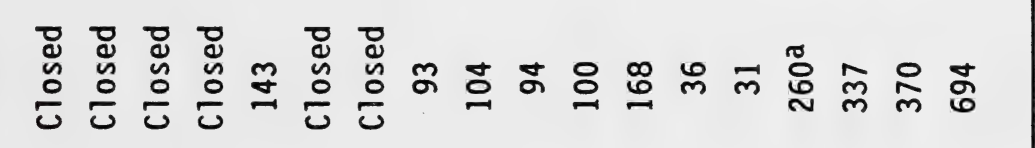 \\
\hline 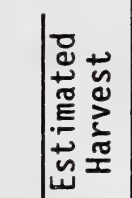 & 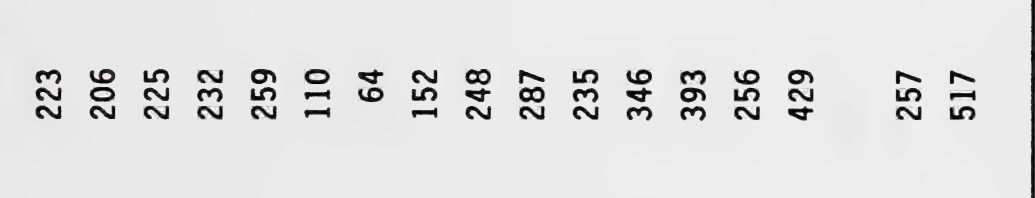 \\
\hline & 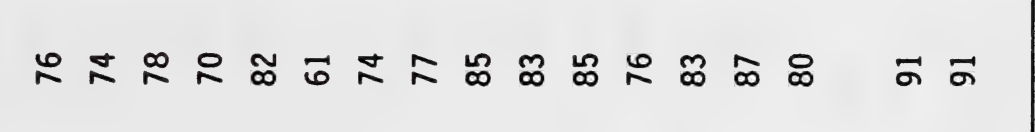 \\
\hline$\underbrace{2}$ & 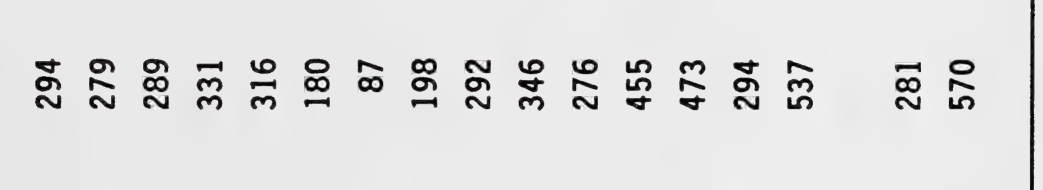 \\
\hline 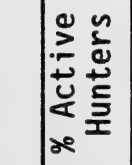 & 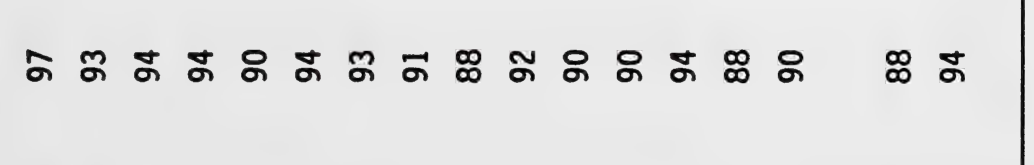 \\
\hline & 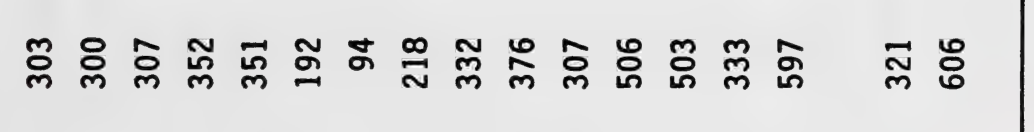 \\
\hline & 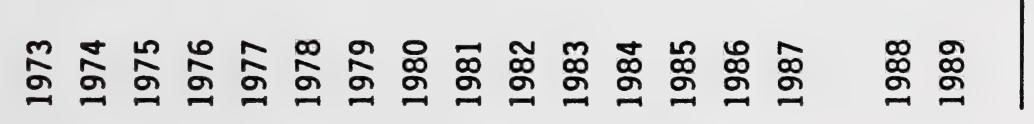 \\
\hline
\end{tabular}




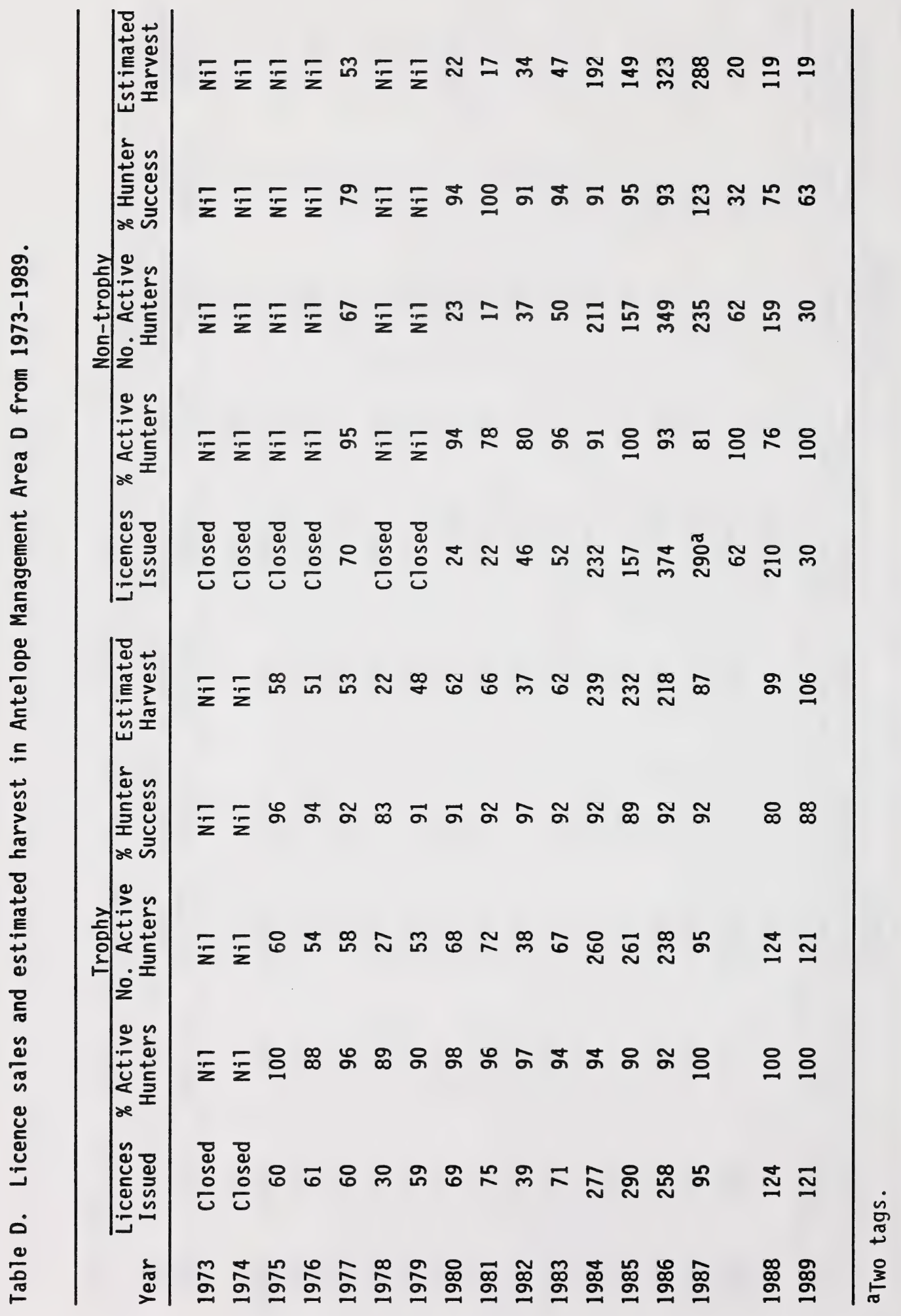




\begin{tabular}{|c|c|}
\hline 唇鳏 & 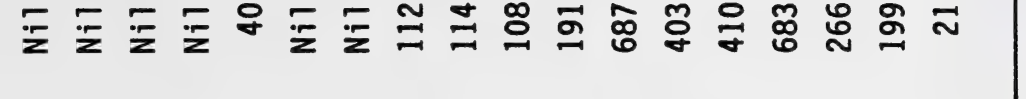 \\
\hline 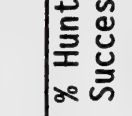 & 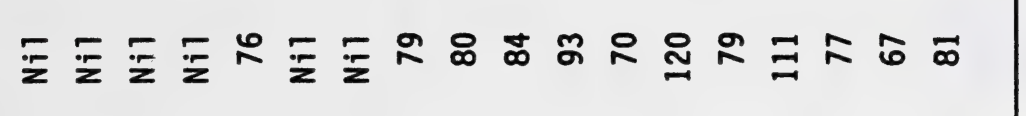 \\
\hline 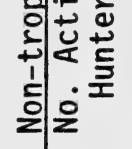 & 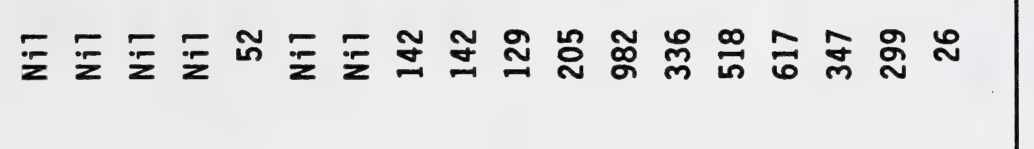 \\
\hline 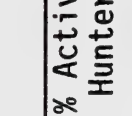 & 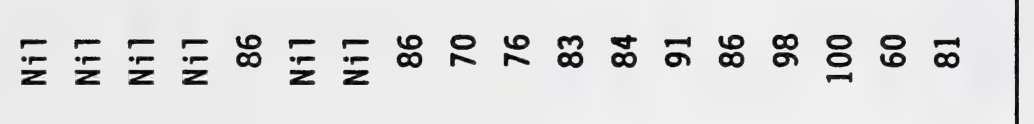 \\
\hline 䈏 & 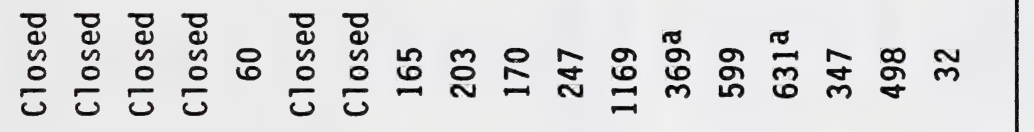 \\
\hline 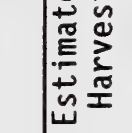 & 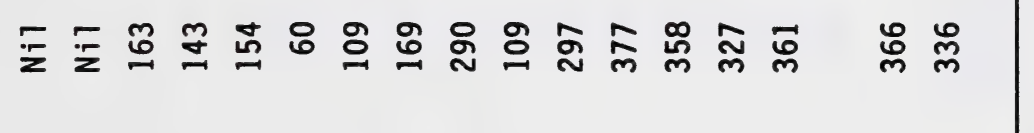 \\
\hline I & 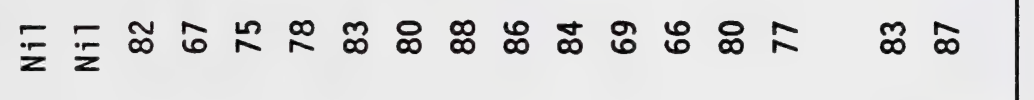 \\
\hline 迹 & 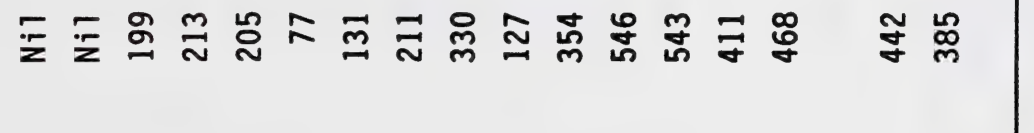 \\
\hline 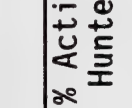 & 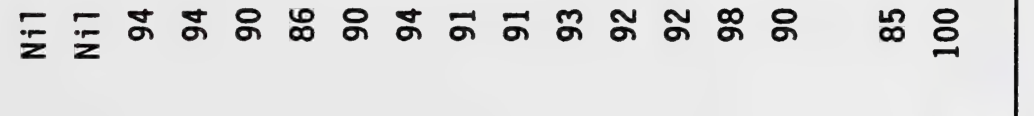 \\
\hline 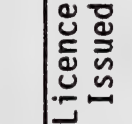 & 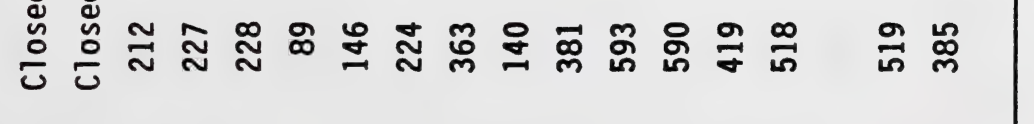 \\
\hline & 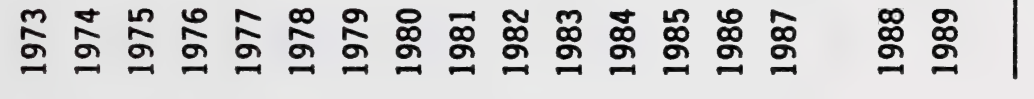 \\
\hline
\end{tabular}




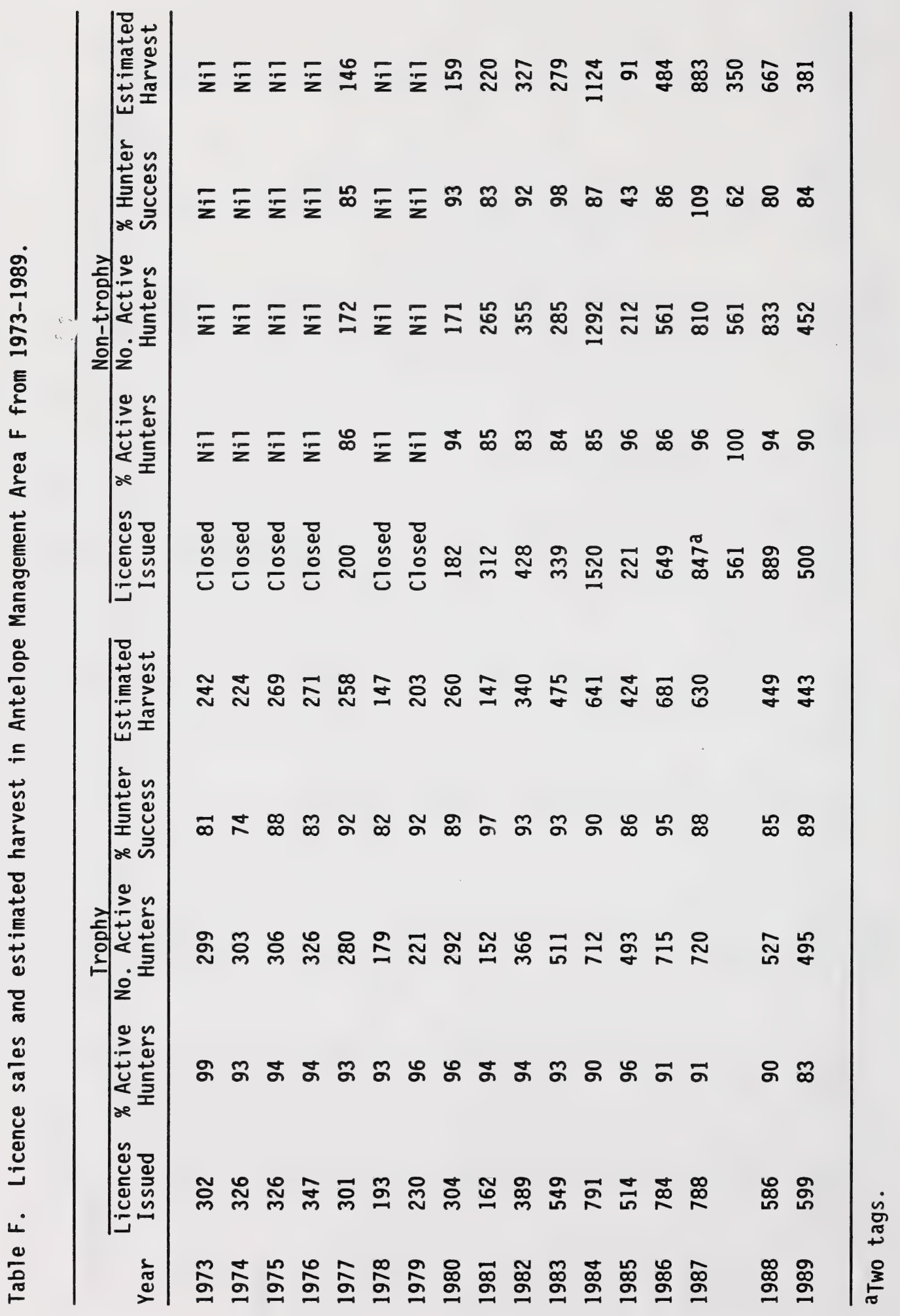




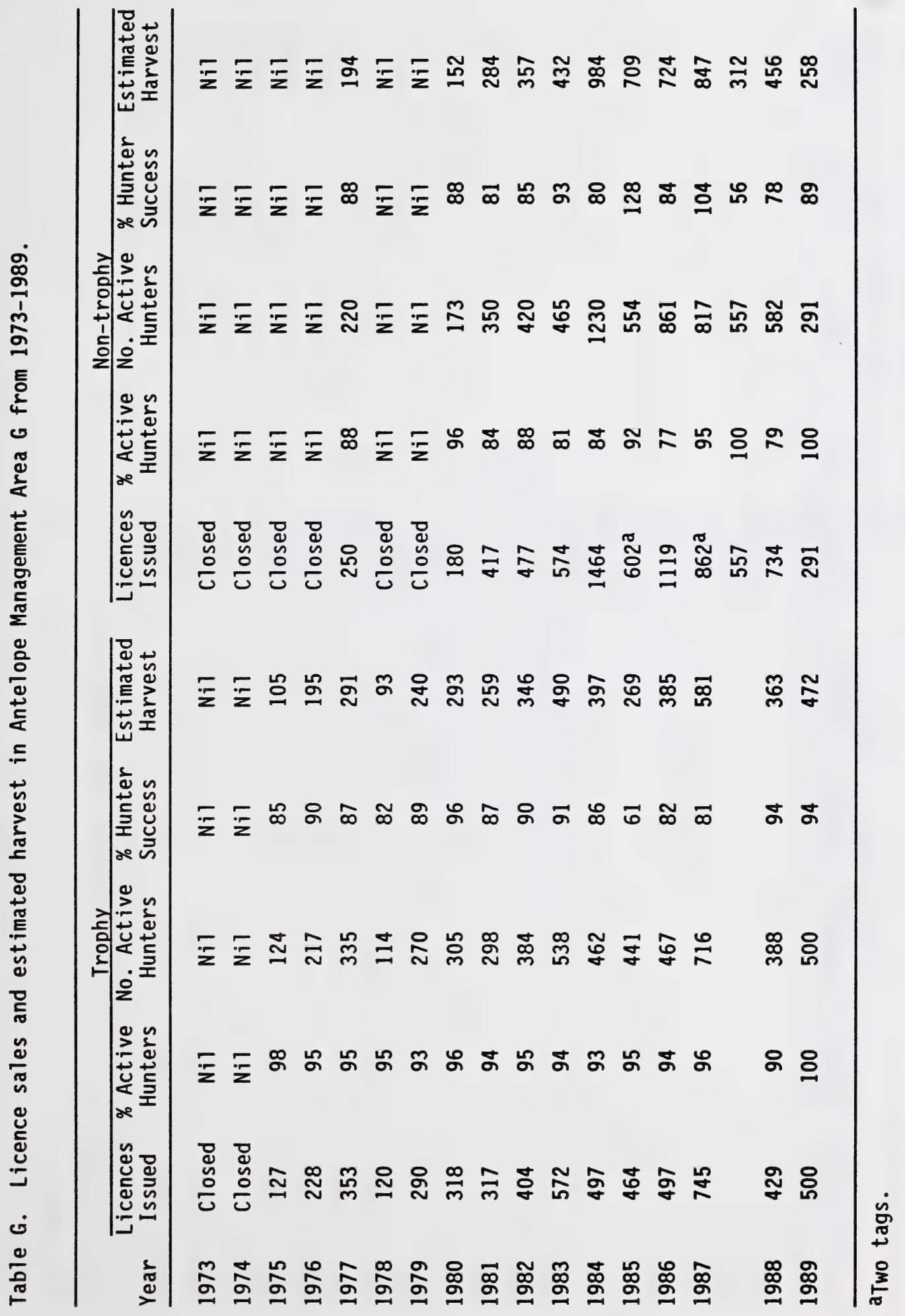




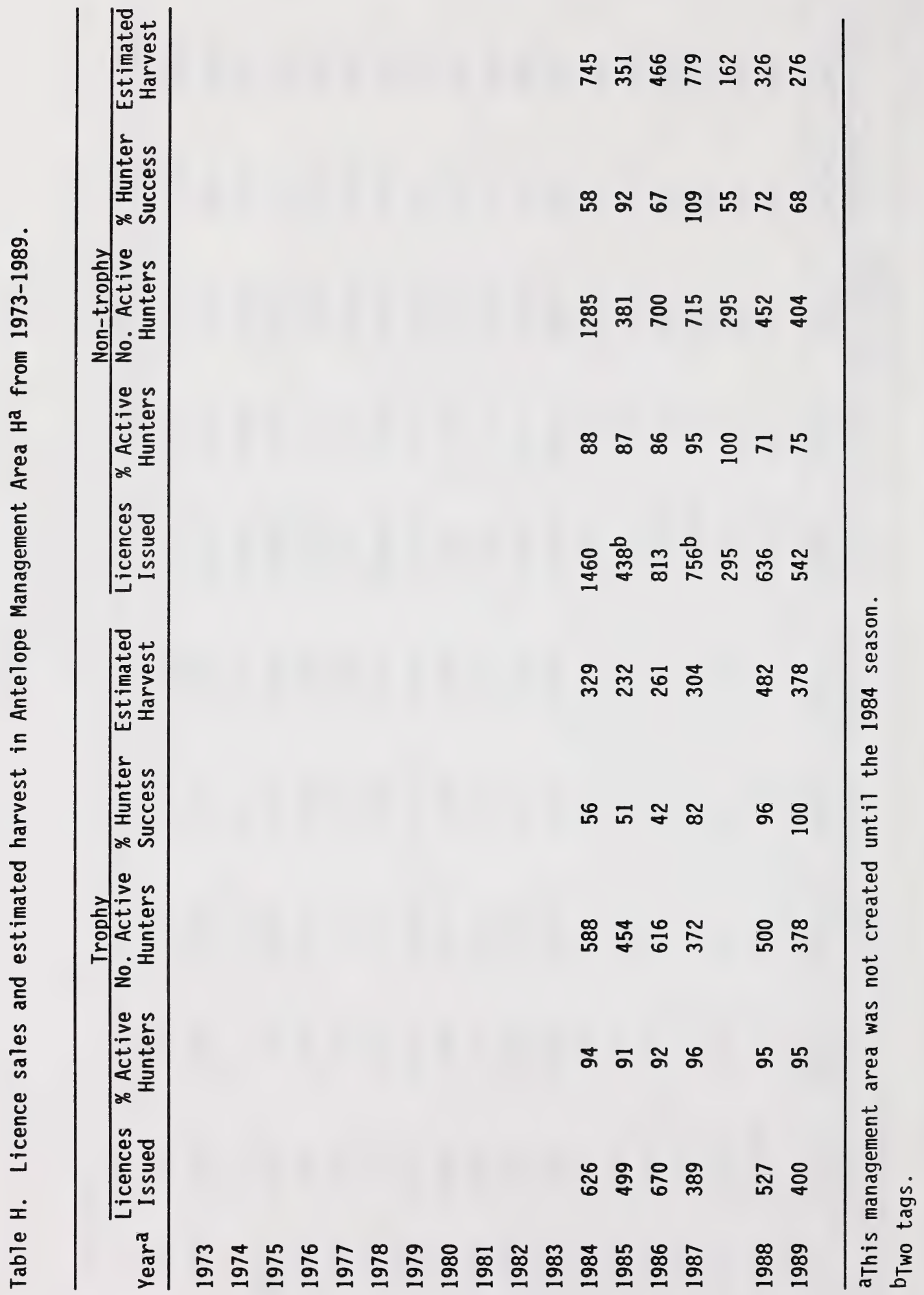




\section{APPENDIX III.}

Pronghorn Antelope Buck:Doe:Fawn Ratios by Antelope Management Area, 1963-1989. Data for all years were adjusted to conform to the geographic boundaries of the current Antelope Management Areas. 
Table A. Pronghorn densities, sex ratios and productivity for Antelope Management Area A from 1963-1989.

\begin{tabular}{|c|c|c|c|c|c|c|c|c|}
\hline \multirow[b]{2}{*}{ Year } & \multirow{2}{*}{$\begin{array}{c}\text { Total } \\
\text { Antelope } \\
\text { On Transect }\end{array}$} & \multirow[b]{2}{*}{$\begin{array}{l}\text { Density } \\
\text { Per } \mathrm{km}^{2}\end{array}$} & \multicolumn{3}{|c|}{$\begin{array}{c}\text { Composition } \\
\text { On and Off Transect } \\
\end{array}$} & \multicolumn{3}{|c|}{ Ratio } \\
\hline & & & Male & Female & Fawn & Buck & Doe & Fawn \\
\hline 1963 & 123 & 0.33 & - & - & - & - & - & - \\
\hline 1964 & 130 & 0.35 & - & - & - & - & - & - \\
\hline 1965 & 155 & 0.46 & - & - & - & - & - & - \\
\hline 1966 & 734 & 0.43 & - & - & - & - & - & - \\
\hline 1967 & 107 & 0.35 & 25 & 51 & 30 & 49 & 100 & 59 \\
\hline 1968 & 290 & 0.52 & 63 & 123 & 118 & 51 & 100 & 96 \\
\hline 1969 & - & - & - & - & - & - & - & - \\
\hline 1970 & 180 & 0.48 & 59 & 88 & 64 & 67 & 100 & 73 \\
\hline 1971 & 259 & 0.69 & 74 & 121 & 100 & 61 & 100 & 83 \\
\hline 1972 & 237 & 0.64 & 84 & 113 & 105 & 74 & 100 & 93 \\
\hline 1973 & 259 & 0.69 & 115 & 184 & 99 & 63 & 100 & 54 \\
\hline 1974 & 358 & 0.96 & 51 & 202 & 116 & 25 & 100 & 57 \\
\hline 1975 & 264 & 0.71 & 60 & 180 & 112 & 33 & 100 & 62 \\
\hline 1976 & 540 & 1.45 & 110 & 295 & 214 & 37 & 100 & 73 \\
\hline 1977 & 642 & 1.72 & 143 & 302 & 258 & 47 & 100 & 85 \\
\hline 1978 & 547 & 1.47 & 136 & 269 & 231 & 51 & 100 & 86 \\
\hline 1979 & 410 & 1.10 & 68 & 234 & 204 & 29 & 100 & 87 \\
\hline 1980 & 661 & 1.77 & 143 & 351 & 225 & 41 & 100 & 64 \\
\hline 1981 & 499 & 1.34 & 133 & 229 & 178 & 58 & 100 & 78 \\
\hline 1982 & 670 & 1.80 & 191 & 383 & 183 & 50 & 100 & 48 \\
\hline 1983 & - & - & - & - & - & - & - & - \\
\hline 1984 & 317 & 1.02 & 74 & 170 & 110 & 44 & 100 & 65 \\
\hline 1985 & 288 & 0.93 & 65 & 146 & 77 & 45 & 100 & 53 \\
\hline 1986 & 190 & 0.61 & 44 & 104 & 60 & 42 & 100 & 58 \\
\hline 1987 & - & - & - & - & - & - & - & - \\
\hline 1988 & 286 & 0.92 & 67 & 141 & 78 & 48 & 100 & 55 \\
\hline 1989 & - & - & - & - & - & - & - & - \\
\hline TOTAL & 8146 & 0.84 & 1705 & 3686 & 2562 & 46 & 100 & 70 \\
\hline
\end{tabular}


Table B. Pronghorn densities, sex ratios and productivity for Antelope Management Area B from 1963-1989.

\begin{tabular}{|c|c|c|c|c|c|c|c|c|}
\hline \multirow[b]{2}{*}{ Year } & \multirow{2}{*}{$\begin{array}{c}\text { Total } \\
\text { Antelope } \\
\text { On Transect }\end{array}$} & \multirow[b]{2}{*}{$\begin{array}{l}\text { Density } \\
\text { Per } \text { km² }^{2}\end{array}$} & \multicolumn{3}{|c|}{$\begin{array}{c}\text { Composition } \\
\text { On and Off Transect } \\
\end{array}$} & \multicolumn{3}{|c|}{ Ratio } \\
\hline & & & Male & Female & Fawn & Buck & Doe & Fawn \\
\hline 1963 & 65 & 0.35 & - & - & - & - & - & - \\
\hline 1964 & 81 & 0.44 & - & - & - & - & - & - \\
\hline 1965 & 353 & 0.59 & - & - & - & - & - & - \\
\hline 1966 & 235 & 1.06 & - & - & - & - & - & - \\
\hline 1967 & 107 & 0.38 & 34 & 53 & 17 & 64 & 100 & 32 \\
\hline 1968 & 66 & 0.28 & 12 & 49 & 28 & 24 & 100 & 57 \\
\hline 1969 & - & - & - & - & - & - & - & - \\
\hline 1970 & 153 & 0.62 & 43 & 68 & 46 & 63 & 100 & 68 \\
\hline 1971 & 181 & 0.36 & 55 & 107 & 71 & 51 & 100 & 66 \\
\hline 1972 & 196 & 0.39 & 55 & 122 & 54 & 45 & 100 & 44 \\
\hline 1973 & 58 & 0.12 & 13 & 31 & 14 & 42 & 100 & 45 \\
\hline 1974 & 94 & 0.19 & 7 & 68 & 52 & 10 & 100 & 76 \\
\hline 1975 & 245 & 0.49 & 29 & 168 & 77 & 17 & 100 & 46 \\
\hline 1976 & 168 & 0.34 & 26 & 108 & 54 & 24 & 100 & 50 \\
\hline 1977 & 212 & 0.43 & 34 & 141 & 51 & 24 & 100 & 36 \\
\hline 1978 & 216 & 0.43 & 34 & 111 & 77 & 31 & 100 & 69 \\
\hline 1979 & 268 & 0.36 & 33 & 133 & 124 & 25 & 100 & 93 \\
\hline 1980 & 307 & 0.41 & 86 & 180 & 100 & 48 & 100 & 56 \\
\hline 1981 & 292 & 0.59 & 69 & 141 & 92 & 49 & 100 & 65 \\
\hline 1982 & 275 & 0.55 & 91 & 138 & 65 & 66 & 100 & 47 \\
\hline 1983 & - & - & - & - & - & - & - & - \\
\hline 1984 & 86 & 0.17 & 37 & 176 & 82 & 21 & 100 & 47 \\
\hline 1985 & 47 & 0.09 & 83 & 176 & 64 & 47 & 100 & 36 \\
\hline 1986 & - & - & - & - & - & - & - & - \\
\hline 1987 & - & - & - & - & - & - & - & - \\
\hline 1988 & - & - & - & - & - & - & - & - \\
\hline 1989 & - & - & - & - & - & - & - & - \\
\hline TOTAL & 3705 & 0.39 & 741 & 1970 & 1068 & 38 & 100 & 54 \\
\hline
\end{tabular}


Table C. Pronghorn densities, sex ratios and productivity for Antelope Management Area C from 1963-1989.

\begin{tabular}{|c|c|c|c|c|c|c|c|c|}
\hline \multirow[b]{2}{*}{ Year } & \multirow{2}{*}{$\begin{array}{c}\text { Total } \\
\text { Antelope } \\
\text { On Transect }\end{array}$} & \multirow[b]{2}{*}{$\begin{array}{l}\text { Density } \\
\text { Per } \mathrm{km}^{2}\end{array}$} & \multicolumn{3}{|c|}{$\begin{array}{c}\text { Composition } \\
\text { On and off Transect } \\
\end{array}$} & \multicolumn{3}{|c|}{ Ratio } \\
\hline & & & Male & Female & Fawn & Buck & Doe & Fawn \\
\hline 1963 & 2380 & 0.92 & - & - & - & - & - & - \\
\hline 1964 & 1255 & 0.97 & - & - & - & - & - & - \\
\hline 1965 & 409 & 0.60 & - & - & - & - & - & - \\
\hline 1966 & 2097 & 0.83 & - & - & - & - & - & - \\
\hline 1967 & 256 & 0.42 & 36 & 111 & 83 & 32 & 100 & 75 \\
\hline 1968 & 395 & 0.49 & 108 & 202 & 160 & 53 & 100 & 79 \\
\hline 1969 & - & - & - & - & - & - & - & - \\
\hline 1970 & 619 & 0.66 & 186 & 267 & 219 & 70 & 100 & 82 \\
\hline 1971 & 518 & 0.56 & 135 & 316 & 137 & 43 & 100 & 43 \\
\hline 1972 & 440 & 0.47 & 135 & 236 & 120 & 57 & 100 & 51 \\
\hline 1973 & 536 & 0.57 & 194 & 364 & 117 & 53 & 100 & 32 \\
\hline 1974 & 595 & 0.64 & 143 & 383 & 181 & 37 & 100 & 47 \\
\hline 1975 & 362 & 0.39 & 92 & 255 & 110 & 36 & 100 & 43 \\
\hline 1976 & 651 & 0.70 & 138 & 405 & 258 & 34 & 100 & 64 \\
\hline 1977 & 717 & 0.77 & 195 & 400 & 153 & 49 & 100 & 38 \\
\hline 1978 & 361 & 0.39 & 84 & 225 & 107 & 37 & 100 & 48 \\
\hline 1979 & 617 & 0.66 & 81 & 319 & 248 & 25 & 100 & 78 \\
\hline 1980 & 498 & 0.53 & 122 & 318 & 119 & 38 & 100 & 37 \\
\hline 1981 & 619 & 0.66 & 167 & 342 & 180 & 49 & 100 & 53 \\
\hline 1982 & 664 & 0.71 & 210 & 404 & 186 & 52 & 100 & 46 \\
\hline 1983 & - & - & - & - & - & - & - & - \\
\hline 1984 & 676 & 0.78 & 174 & 429 & 131 & 41 & 100 & 31 \\
\hline 1985 & 516 & 0.59 & 74 & 163 & 50 & 45 & 100 & 31 \\
\hline 1986 & - & - & - & - & - & - & - & - \\
\hline 1987 & 658 & 0.76 & 182 & 413 & 166 & 44 & 100 & 40 \\
\hline 1988 & - & - & - & - & - & - & - & - \\
\hline 1989 & 960 & 1.10 & 294 & 578 & 164 & 51 & 100 & 28 \\
\hline TOTAL & 16799 & 0.69 & 2750 & 6130 & 2889 & 45 & 100 & 47 \\
\hline
\end{tabular}


Table D. Pronghorn densities, sex ratios and productivity for Antelope Management Area D from 1963-1989.

\begin{tabular}{|c|c|c|c|c|c|c|c|c|}
\hline \multirow[b]{2}{*}{ Year } & \multirow{2}{*}{$\begin{array}{c}\text { Total } \\
\text { Antelope } \\
\text { On Transect }\end{array}$} & \multirow[b]{2}{*}{$\begin{array}{l}\text { Density } \\
\text { Per } \mathrm{km}^{2}\end{array}$} & \multicolumn{3}{|c|}{$\begin{array}{c}\text { Composition } \\
\text { on and Off Transect } \\
\end{array}$} & \multicolumn{3}{|c|}{ Ratio } \\
\hline & & & Male & Female & Fawn & Buck & Doe & Fawn \\
\hline 1963 & 93 & 0.50 & - & - & - & - & - & - \\
\hline 1964 & 78 & 0.42 & - & - & - & - & - & - \\
\hline 1965 & 36 & 0.19 & - & - & - & - & - & - \\
\hline 1966 & 30 & 0.16 & - & - & - & - & - & - \\
\hline 1967 & 37 & 0.07 & 7 & 17 & 13 & 41 & 100 & 76 \\
\hline 1968 & 43 & 0.13 & 6 & 22 & 19 & 27 & 100 & 86 \\
\hline 1969 & - & - & - & - & - & - & - & - \\
\hline 1970 & - & - & - & - & - & - & - & - \\
\hline 1971 & - & - & - & - & - & - & - & - \\
\hline 1972 & - & - & - & - & - & - & - & - \\
\hline 1973 & - & - & - & - & - & - & - & - \\
\hline 1974 & - & - & - & - & - & - & - & - \\
\hline 1975 & 177 & 0.74 & 71 & 85 & 52 & 84 & 100 & 61 \\
\hline 1976 & 353 & 1.48 & 120 & 110 & 131 & 109 & 100 & 119 \\
\hline 1977 & 211 & 1.23 & 98 & 173 & 102 & 57 & 100 & 59 \\
\hline 1978 & 90 & 0.38 & 18 & 52 & 40 & 35 & 100 & 77 \\
\hline 1979 & 330 & 1.06 & 49 & 146 & 147 & 34 & 100 & 101 \\
\hline 1980 & 371 & 1.19 & 96 & 246 & 142 & 39 & 100 & 58 \\
\hline 1981 & 244 & 0.79 & 89 & 140 & 97 & 64 & 100 & 69 \\
\hline 1982 & 253 & 0.81 & 45 & 119 & 91 & 38 & 100 & 76 \\
\hline 1983 & - & - & - & - & - & - & - & - \\
\hline 1984 & 656 & 2.01 & 193 & 294 & 209 & 66 & 100 & 71 \\
\hline 1985 & 266 & 1.04 & 100 & 129 & 89 & 78 & 100 & 69 \\
\hline 1986 & - & - & - & - & - & - & - & - \\
\hline 1987 & 254 & 0.99 & 49 & 163 & 96 & 30 & 100 & 59 \\
\hline 1988 & - & - & - & - & - & - & - & - \\
\hline 1989 & 180 & 0.70 & 67 & 70 & 50 & 96 & 100 & 71 \\
\hline TOTAL & 3702 & 0.77 & 1008 & 1766 & 1278 & 57 & 100 & 73 \\
\hline
\end{tabular}


Table E. Pronghorn densities, sex ratios and productivity for Antelope Management Area E from 1963-1989.

\begin{tabular}{|c|c|c|c|c|c|c|c|c|}
\hline \multirow[b]{2}{*}{ Year } & \multirow{2}{*}{$\begin{array}{c}\text { Total } \\
\text { Antelope } \\
\text { On Transect }\end{array}$} & \multirow{2}{*}{$\begin{array}{l}\text { Density } \\
\text { Per } \mathrm{km}^{2}\end{array}$} & \multicolumn{3}{|c|}{$\begin{array}{c}\text { Composition } \\
\text { On and off Transect } \\
\end{array}$} & \multicolumn{3}{|c|}{ Ratio } \\
\hline & & & Male & Female & Fawn & Buck & Doe & Fawn \\
\hline 1963 & 3584 & 1.39 & - & - & - & - & - & - \\
\hline 1964 & 4049 & 1.58 & - & - & - & - & - & - \\
\hline 1965 & 354 & 0.50 & - & - & - & - & - & - \\
\hline 1966 & 565 & 0.48 & - & - & - & - & - & - \\
\hline 1967 & 240 & 0.24 & 48 & 92 & 59 & 52 & 100 & 64 \\
\hline 1968 & - & - & - & - & - & - & - & - \\
\hline 1969 & - & - & - & - & - & - & - & - \\
\hline 1970 & 187 & 0.33 & 77 & 90 & 20 & 86 & 100 & 22 \\
\hline 1971 & 145 & 0.14 & 29 & 99 & 52 & 29 & 100 & 53 \\
\hline 1972 & 331 & 0.32 & 92 & 157 & 117 & 59 & 100 & 75 \\
\hline 1973 & 234 & 0.23 & 97 & 101 & 70 & 96 & 100 & 69 \\
\hline 1974 & 264 & 0.31 & 50 & 137 & 96 & 36 & 100 & 70 \\
\hline 1975 & 538 & 0.63 & 152 & 267 & 184 & 57 & 100 & 69 \\
\hline 1976 & 522 & 0.61 & 167 & 293 & 257 & 57 & 100 & 88 \\
\hline 1977 & 549 & 0.82 & 146 & 304 & 209 & 48 & 100 & 69 \\
\hline 1978 & 227 & 0.34 & 58 & 92 & 89 & 63 & 100 & 97 \\
\hline 1979 & 455 & 0.53 & 94 & 215 & 217 & 44 & 100 & 101 \\
\hline 1980 & 658 & 0.77 & 204 & 388 & 277 & 53 & 100 & 71 \\
\hline 1981 & 667 & 0.64 & 163 & 351 & 297 & 46 & 100 & 85 \\
\hline 1982 & 717 & 0.69 & 158 & 516 & 418 & 31 & 100 & 81 \\
\hline 1983 & - & - & - & - & - & - & - & - \\
\hline 1984 & 1109 & 1.30 & 246 & 591 & 424 & 42 & 100 & 72 \\
\hline 1985 & 696 & 1.70 & 163 & 365 & 230 & 45 & 100 & 63 \\
\hline 1986 & 555 & 1.24 & 119 & 309 & 235 & 39 & 100 & 76 \\
\hline 1987 & 722 & 1.67 & 163 & 342 & 286 & 48 & 100 & 84 \\
\hline 1988 & 381 & 1.05 & 122 & 240 & 113 & 51 & 100 & 47 \\
\hline 1989 & 345 & 0.80 & 107 & 161 & 82 & 66 & 100 & 51 \\
\hline TOTAL & 18094 & 0.81 & 2455 & 5110 & 3732 & 48 & 100 & 73 \\
\hline
\end{tabular}


Table F. Pronghorn densities, sex ratios and productivity for Antelope Management Area F from 1963-1989.

\begin{tabular}{|c|c|c|c|c|c|c|c|c|}
\hline \multirow[b]{2}{*}{ Year } & \multirow{2}{*}{$\begin{array}{c}\text { Total } \\
\text { Antelope } \\
\text { On Transect }\end{array}$} & \multirow[b]{2}{*}{$\begin{array}{l}\text { Density } \\
\text { Per } \mathrm{km}^{2}\end{array}$} & \multicolumn{3}{|c|}{$\begin{array}{c}\text { Composition } \\
\text { On and Off Transect } \\
\end{array}$} & \multicolumn{3}{|c|}{ Ratio } \\
\hline & & & Male & Female & Fawn & Buck & Doe & Fawn \\
\hline 1963 & 1018 & 0.50 & - & - & - & - & - & - \\
\hline 1964 & 1025 & 0.61 & - & - & - & - & - & - \\
\hline 1965 & 1205 & 0.55 & - & - & - & - & - & - \\
\hline 1966 & 563 & 0.41 & - & - & - & - & - & - \\
\hline 1967 & 778 & 0.47 & 174 & 285 & 189 & 61 & 100 & 66 \\
\hline 1968 & 783 & 0.41 & 229 & 381 & 300 & 60 & 100 & 79 \\
\hline 1969 & - & - & - & - & - & - & - & - \\
\hline 1970 & 561 & 0.75 & 93 & 243 & 202 & 38 & 100 & 83 \\
\hline 1971 & 522 & 0.52 & 176 & 255 & 184 & 69 & 100 & 72 \\
\hline 1972 & 534 & 0.54 & 154 & 263 & 197 & 59 & 100 & 75 \\
\hline 1973 & 655 & 0.66 & 95 & 389 & 207 & 24 & 100 & 53 \\
\hline 1974 & 524 & 0.53 & 91 & 318 & 187 & 29 & 100 & 59 \\
\hline 1975 & 516 & 0.52 & 136 & 344 & 156 & 40 & 100 & 45 \\
\hline 1976 & 587 & 0.59 & 149 & 314 & 217 & 47 & 100 & 69 \\
\hline 1977 & 591 & 0.59 & 126 & 420 & 227 & 30 & 100 & 54 \\
\hline 1978 & 473 & 0.47 & 78 & 290 & 180 & 27 & 100 & 62 \\
\hline 1979 & 485 & 0.49 & 93 & 231 & 232 & 40 & 100 & 100 \\
\hline 1980 & 579 & 0.58 & 137 & 319 & 188 & 43 & 100 & 59 \\
\hline 1981 & 870 & 0.87 & 144 & 482 & 317 & 30 & 100 & 66 \\
\hline 1982 & 609 & 0.61 & 205 & 307 & 153 & 67 & 100 & 50 \\
\hline 1983 & - & - & - & - & - & - & - & - \\
\hline 1984 & 1109 & 0.90 & 293 & 580 & 317 & 51 & 100 & 55 \\
\hline 1985 & 582 & 0.47 & 140 & 314 & 188 & 45 & 100 & 60 \\
\hline 1986 & 933 & 0.76 & 227 & 580 & 336 & 39 & 100 & 58 \\
\hline 1987 & - & - & - & - & - & - & - & - \\
\hline 1988 & 850 & 0.69 & 187 & 476 & 226 & 39 & 100 & 47 \\
\hline 1989 & - & - & - & - & - & - & - & - \\
\hline TOTAL & 16352 & 0.57 & 2327 & 6791 & 4203 & 43 & 100 & 62 \\
\hline
\end{tabular}


Table G. Pronghorn densities, sex ratios and productivity for Antelope Management Area G from 1963-1989.

\begin{tabular}{|c|c|c|c|c|c|c|c|c|}
\hline \multirow[b]{2}{*}{ Year } & \multirow{2}{*}{$\begin{array}{c}\text { Total } \\
\text { Antelope } \\
\text { On Transect }\end{array}$} & \multirow[b]{2}{*}{$\begin{array}{l}\text { Density } \\
\text { Per } \mathrm{km}^{2}\end{array}$} & \multicolumn{3}{|c|}{$\begin{array}{c}\text { Composition } \\
\text { On and Off Transect } \\
\end{array}$} & \multicolumn{3}{|c|}{ Ratio } \\
\hline & & & Male & Female & Fawn & Buck & Doe & Fawn \\
\hline 1963 & 473 & 0.55 & - & - & - & - & - & - \\
\hline 1964 & 384 & 0.83 & - & - & - & - & - & - \\
\hline 1965 & 373 & 0.44 & - & - & - & - & - & - \\
\hline 1966 & 1079 & 0.41 & - & - & - & - & - & - \\
\hline 1967 & 310 & 0.20 & 40 & 122 & 88 & 33 & 100 & 72 \\
\hline 1968 & - & - & - & - & - & - & - & - \\
\hline 1969 & - & - & - & - & - & - & - & - \\
\hline 1970 & 158 & 0.26 & 54 & 63 & 41 & 86 & 100 & 65 \\
\hline 1971 & 84 & 0.16 & 11 & 55 & 28 & 20 & 100 & 51 \\
\hline 1972 & 85 & 0.16 & 12 & 45 & 34 & 27 & 100 & 76 \\
\hline 1973 & 103 & 0.20 & 10 & 61 & 37 & 16 & 100 & 61 \\
\hline 1974 & 163 & 0.31 & 20 & 81 & 62 & 25 & 100 & 77 \\
\hline 1975 & 67 & 0.22 & 15 & 52 & 35 & 29 & 100 & 67 \\
\hline 1976 & 190 & 0.63 & 31 & 93 & 75 & 33 & 100 & 81 \\
\hline 1977 & 71 & 0.14 & 15 & 45 & 18 & 33 & 100 & 40 \\
\hline 1978 & 82 & 0.16 & 2 & 52 & 28 & 4 & 100 & 54 \\
\hline 1979 & 154 & 0.26 & 18 & 40 & 38 & 45 & 100 & 95 \\
\hline 1980 & 243 & 0.40 & 24 & 88 & 70 & 27 & 100 & 80 \\
\hline 1981 & 87 & 0.16 & 17 & 41 & 29 & 41 & 100 & 71 \\
\hline 1982 & 132 & 0.25 & 35 & 85 & 46 & 41 & 100 & 54 \\
\hline 1983 & - & - & - & - & - & - & - & - \\
\hline 1984 & 567 & 0.53 & 144 & 346 & 176 & 42 & 100 & 51 \\
\hline 1985 & 370 & 0.41 & 43 & 156 & 75 & 28 & 100 & 48 \\
\hline 1986 & - & - & - & - & - & - & - & - \\
\hline 1987 & 599 & 0.63 & 141 & 317 & 214 & 44 & 100 & 68 \\
\hline 1988 & - & - & - & - & - & - & - & - \\
\hline 1989 & 343 & 0.36 & 106 & 170 & 89 & 62 & 100 & 52 \\
\hline TOTAL & 6117 & 0.36 & 738 & 1912 & 1183 & 39 & 100 & 62 \\
\hline
\end{tabular}


Table H. Pronghorn densities, sex ratios and productivity for Antelope Management Area H from 1963-1989.

\begin{tabular}{|c|c|c|c|c|c|c|c|c|}
\hline \multirow[b]{2}{*}{ Year } & \multirow{2}{*}{$\begin{array}{c}\text { Total } \\
\text { Antelope } \\
\text { On Transect }\end{array}$} & \multirow[b]{2}{*}{$\begin{array}{l}\text { Density } \\
\text { Per } \mathrm{km}^{2}\end{array}$} & \multicolumn{3}{|c|}{$\begin{array}{c}\text { Composition } \\
\text { On and Off Transect } \\
\end{array}$} & \multicolumn{3}{|c|}{ Ratio } \\
\hline & & & Male & Female & Fawn & Buck & Doe & Fawn \\
\hline 1963 & 748 & 0.32 & - & - & - & - & - & - \\
\hline 1964 & 695 & 0.29 & - & - & - & - & - & - \\
\hline 1965 & 529 & 0.19 & - & - & - & - & - & - \\
\hline 1966 & 547 & 0.21 & - & - & - & - & - & - \\
\hline 1967 & 229 & 0.09 & 36 & 119 & 63 & 30 & 100 & 53 \\
\hline 1968 & - & - & - & - & - & - & - & - \\
\hline 1969 & - & - & - & - & - & - & - & - \\
\hline 1970 & - & - & - & - & - & - & - & - \\
\hline 1971 & 16 & 0.04 & 4 & 5 & 7 & 80 & 100 & 140 \\
\hline 1972 & 20 & 0.08 & 13 & 5 & 3 & 260 & 100 & 60 \\
\hline 1973 & 22 & 0.09 & 19 & 16 & 10 & 119 & 100 & 63 \\
\hline 1974 & 25 & 0.10 & 6 & 15 & 4 & 40 & 100 & 27 \\
\hline 1975 & 49 & 0.10 & 23 & 12 & 3 & 192 & 100 & 25 \\
\hline 1976 & 110 & 0.22 & 65 & 46 & 29 & 141 & 100 & 63 \\
\hline 1977 & 90 & 0.18 & 45 & 92 & 62 & 49 & 100 & 67 \\
\hline 1978 & 74 & 0.15 & 15 & 32 & 27 & 47 & 100 & 84 \\
\hline 1979 & 381 & 0.33 & 99 & 73 & 57 & 136 & 100 & 78 \\
\hline 1980 & 361 & 0.31 & 76 & 132 & 81 & 58 & 100 & 61 \\
\hline 1981 & 496 & 0.49 & 112 & 274 & 175 & 41 & 100 & 64 \\
\hline 1982 & 396 & 0.39 & 61 & 166 & 87 & 37 & 100 & 52 \\
\hline 1983 & - & - & - & - & - & - & - & - \\
\hline 1984 & 631 & 0.50 & 167 & 384 & 211 & 43 & 100 & 55 \\
\hline 1985 & 552 & 0.41 & 151 & 351 & 202 & 43 & 100 & 58 \\
\hline 1986 & 520 & 0.46 & 131 & 326 & 203 & 40 & 100 & 62 \\
\hline 1987 & - & - & - & - & - & - & - & - \\
\hline 1988 & 362 & 0.32 & 119 & 218 & 158 & 55 & 100 & 72 \\
\hline 1989 & - & - & - & - & - & - & - & - \\
\hline TOTAL & 6853 & 0.19 & 1142 & 2266 & 1382 & 50 & 100 & 60 \\
\hline
\end{tabular}


Table I. Pronghorn densities, sex ratios and productivity for Suffield from 1963-1989.

Composition

Total

Antelope

Year On Transect
On and Off Transect

Density

Male Female Fawn
1963

1964

1965

1966

1967

1968

1969

1970

1971

1972

1973

1974

1975

1976

1977

1978

1979

1980

1981

1982

1983

1984

1985

1986

1987

1988

1989
878

814

594

670

413

618

844

804

686

757

1310

691

620

769

369

884
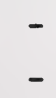

735

426
0.69

0.64

0.47

0.53

0.33

0.49

0.67

0.68

0.54

0.81

1.03

0.55

0.99

1.22

0.83

1.40

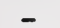

1.17

0.68
103

164

288

264

232

287

388

165

149

193

131

378

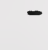

232

103
127

191

182

274

187

280

384

210

240

254

110

222

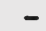

146

116
Ratio

Buck Doe Fawn
$53 \quad 100$

$54 \quad 100$

$66 \quad 100$

$68 \quad 100$

$69 \quad 100$

$73 \quad 100$

61100

$50 \quad 100$

$59 \quad 100$

$56 \quad 100$

$89 \quad 100$

103100

\begin{tabular}{ccc} 
& & \\
& Ratio & \\
\hline & Doe & Fawn \\
\hline & - & - \\
- & - & - \\
& - & - \\
& - & - \\
& - & - \\
& - & - \\
& - & - \\
& - & - \\
53 & 100 & 65 \\
54 & 100 & 63 \\
66 & 100 & 42 \\
68 & 100 & 70 \\
69 & 100 & 56 \\
73 & 100 & 71 \\
61 & 100 & 60 \\
50 & 100 & 64 \\
59 & 100 & 95 \\
56 & 100 & 74 \\
89 & 100 & 74 \\
03 & 100 & 61 \\
- & - & - \\
& - & -
\end{tabular}

\begin{tabular}{ccc}
- & - & - \\
64 & 100 & 40 \\
50 & 100 & 50 \\
- & - & - \\
- & - & - \\
- & - & - \\
65 & 100 & 62 \\
\hline
\end{tabular}

TOTAL 12882

0.70

3077

4701

2923 
APPENDIX IV.

Provincial Pronghorn Antelope Survey Format. 


\section{SURVEY TECHNIOUE}

\section{TIMING}

1. One half of the Antelope Management Areas in each of the Central and Southern Regions will be surveyed on an annual, rotating basis.

2. At least one block will be surveyed per Wildlife Management Unit in each Antelope Management Area being surveyed.

3. Antelope inventories will begin July 15 and block coverage for the Southern and Central Regions will be concurrent and consistent with Table A.

4. Daily inventory coverage will be provided by two flights with pre-scheduled departures of 0600 and 1600 hours. The duration of each flight will not exceed four hours.

\section{METHODOLOGY}

1. Every transect line within scheduled monitor blocks will receive aerial coverage by accurately flying the fixed wing aircraft along each line at an altitude of $60 \mathrm{~m}$ - $90 \mathrm{~m}$ above ground level and a ground speed of $120 \mathrm{~km} / \mathrm{h}-160 \mathrm{~km} / \mathrm{h}$. Altitude and airspeed are ultimately governed by the terrain being traversed and the prevailing wind conditions.

2. The inventory crew will consist of four experienced survey personnel including a pilot, navigator and two primary observers. The two primary observers will occupy the rear seats and each is responsible for continuous visual coverage of a $0.8 \mathrm{~km}(0.5 \mathrm{mi.})$ scan strip. The navigator, seated right of the pilot, is responsible for maintaining an accurate course, recording all pertinent information on data forms and maps, judging observations as either "on" or "off" transect, aiding with herd classifications and assisting with observing duties as time permits. 
TABLE A. Specific monitor blocks to be surveyed over a three-year term (1985-87).

\begin{tabular}{|c|c|c|c|c|c|}
\hline \multirow{2}{*}{ AMA $^{a}$} & \multirow{2}{*}{ WMUb } & \multirow{2}{*}{ Block } & \multicolumn{3}{|c|}{ Year } \\
\hline & & & 1985 & 1986 & 1987 \\
\hline$A$ & 108 & $A$ & $x$ & $x$ & \\
\hline B & $\begin{array}{l}104 / 106 \\
112\end{array}$ & $\begin{array}{l}H \\
S F\end{array}$ & $\begin{array}{l}x \\
x\end{array}$ & & $\begin{array}{l}x \\
x\end{array}$ \\
\hline C & 102 & $B \& C$ & $x$ & & \\
\hline$D$ & $128 / 140$ & MA & $x$ & & $x$ \\
\hline$E$ & $\begin{array}{l}138 \\
142 \\
144\end{array}$ & $\begin{array}{l}\mathrm{K} \\
\mathrm{N} \\
\mathrm{R}, \mathrm{T}, \mathrm{J}\end{array}$ & $\begin{array}{l}x \\
x \\
x\end{array}$ & $\begin{array}{l}x \\
x \\
x\end{array}$ & \\
\hline$F$ & $\begin{array}{l}116 \\
119 \\
124 \\
148\end{array}$ & $\begin{array}{l}I \\
E \\
B W \\
F \& G\end{array}$ & $\begin{array}{l}x \\
x \\
x \\
x\end{array}$ & $\begin{array}{l}x \\
x \\
x \\
x\end{array}$ & \\
\hline
\end{tabular}

\begin{tabular}{|c|c|c|c|c|c|}
\hline \multicolumn{3}{|c|}{ Southern Total } & \multirow{2}{*}{$\begin{array}{l}16 \\
x \\
x \\
x\end{array}$} & \multirow[t]{2}{*}{11} & \multirow{2}{*}{$\begin{array}{l}5 \\
x \\
x \\
x\end{array}$} \\
\hline$G$ & $\begin{array}{l}150 \\
151 \\
152\end{array}$ & $\begin{array}{l}B J \\
A C \& \& \\
E B, P, 0\end{array}$ & & & \\
\hline H & $\begin{array}{l}160 \\
162 \\
164\end{array}$ & ${ }_{U}^{0} \mathrm{BC}, P \& V, R S$ & $\begin{array}{l}x \\
x \\
x\end{array}$ & $\begin{array}{l}x \\
x \\
x\end{array}$ & \\
\hline
\end{tabular}

\begin{tabular}{lrrr}
\hline Central Total & 9 & 4 & 5 \\
\hline Provincial Total & 25 & 15 & 10 \\
\hline
\end{tabular}

aAMA - Antelope Management Area.

bWMU - Wildlife Management Unit. 
3. All "on" transect observations are accurately counted, classified (bucks, does and kids) and separately recorded per transect line. In many instances this information for small herds can be achieved without deviating from the transect line. Such information for large herds requires a cooperative effort by the navigator (kid count) and right rear observer (buck and total count) and may require multiple checks until confidence in the count can be established. The doe segment is calculated by subtracting the two known components from the total count. In many cases the left rear observer can participate in this exercise thus providing an accuracy check.

4. When it is apparent that sample sizes on monitor blocks are relatively small, "off" transect observations should be similarly counted and classified to increase the sample size and hence accuracy of projected sex/age ratios. All such information is separately notated and excluded from density projections.

5. This survey format was implemented in 1986 as per Table B. 
Table B: Provincial survey design for antelope (to be initiated in 1986).

\begin{tabular}{|c|c|c|c|c|c|c|}
\hline \multirow[b]{3}{*}{ Region } & \multicolumn{3}{|c|}{ Year 1} & \multicolumn{3}{|c|}{ Year 2} \\
\hline & & & Aircraft & & & Aircraft \\
\hline & AMA ${ }^{a}$ & Hours ${ }^{b}$ & $\operatorname{cost}(\$)^{c}$ & AMA ${ }^{a}$ & Hours ${ }^{b}$ & $\operatorname{cost}(\$)^{C}$ \\
\hline \multirow[t]{3}{*}{ Southern } & A & 4 & 640 & B & 3 & 480 \\
\hline & $E$ & 8 & 1280 & C & 8 & 1280 \\
\hline & $F$ & 11 & 1760 & D & 6 & 960 \\
\hline Sub-Total & & 23 & 3680 & & 17 & 2720 \\
\hline Central & H & 10 & 1600 & G & 10 & 1600 \\
\hline Sub-Total & & 10 & 1600 & & 10 & 1600 \\
\hline Total & & 33 & 5280 & & 27 & 4320 \\
\hline
\end{tabular}

aAMA - Antelope Management Area.

$\mathrm{b}_{\mathrm{A} 11}$ hours are for fixed-wing aircraft.

cCost calculated using: $\$ 160.00 /$ hour fixed wing (Charter - "dry" rate). 
APPENDIX V.

Ingredient List For Experimental Rations Used in Feeding Trials With Wild Pronghorns. 
Ingredient list for experimental rations used in field trials with wild pronghorn antelope in 1983 in Colorado and the winter of 1985-86 in Alberta.

\begin{tabular}{ll}
\hline & List of Ingredients \\
\hline Alberta Ration & Colorado Ration \\
\hline Bentonite & Bentonite \\
Barley & Barley \\
Corn & Corn \\
Canola Meala & Milo \\
Oats & Oats \\
Wheat Mids & Wheat Mids \\
Beet Pulp & Beet Pulp \\
Distiller's Grainb & Dry Brewer's Grain \\
Molasses & Molasses \\
Trace Mineral Package & Trace Mineral Package \\
Vitamin Package & Vitamin Package \\
(Vitamin E 20 units/kilo) & (Vitamin E 20 units/kilo) \\
\hline
\end{tabular}

aCanola Meal was substituted for Milo in the Alberta ration because of the availability of the product in western Canada.

bDistiller's Grain is an analogous name for Dehydrated Brewer's Grain. 


\section{APPENDIX VI.}

Pronghorn Antelope Stable Population Model for Alberta. 


\begin{tabular}{|c|c|c|c|c|c|c|}
\hline \multirow[b]{2}{*}{ Time } & \multicolumn{3}{|c|}{ Females } & \multicolumn{3}{|c|}{ Males } \\
\hline & Adult & Yrlg. & Fawn & Adult & Yrlg. & Fawn \\
\hline Spring & 1000 & 293 & 1000 & 284 & 293 & 1000 \\
\hline Summer Mortality & $10(1 \%)$ & $3(1 \%)$ & $600(60 \%)$ & $3(1 \%)$ & $3(1 \%)$ & $600(60 \%)$ \\
\hline Fall (Preseason) & 990 & 290 & 400 & 281 & 290 & 400 \\
\hline Hunting Mortality & $129(13 \%)$ & $48(17 \%)$ & $27(7 \%)$ & $189(67 \%)$ & $57(20 \%)$ & $27(7 \%)$ \\
\hline Fall (Postseason) & 861 & 242 & 373 & 92 & 233 & 373 \\
\hline Winter Mortality & $76(9 \%)$ & $27(11 \%)$ & $80(21 \%)$ & $15(16 \%)$ & $26(11 \%)$ & $80(21 \%)$ \\
\hline Spring & $785+215$ & 293 & & $77+207$ & 293 & \\
\hline
\end{tabular}

Spring Sex Ratio

Fall (Preseason)

Fall (Postseason)

Late Winter
45 bucks: 100 does

45 bucks: 100 does: 63 fawns

30 bucks: 100 does: 68 fawns

28 bucks:100 does:59 fawns

The preseason population is $\frac{2641}{2174}=1.21$ times larger than postseason 2174

$\frac{2651}{1870}=1.42$ times larger than late winter 1870

Annual Recruitment $=$ Number of Spring Yearlings $=0.29$ Spring Yearlings + Adults 


\section{Rationale for the Pronghorn Antelope Stable Population Model for Alberta}

1. It was assumed that the number of fawns per doe at birth was 2 for does older than one year and 0 for yearlings (Mitchell 1980, Barrett 1981).

2. It was assumed that the survival rate for fawns through to the fall preseason was 40 percent (Barrett 1982, Summer Population Surveys 1963-1985).

3. It was assumed that the annual mortality between fall preseason and the following spring was 29 percent. This was calculated by comparing preseason estimates of one year with predicted spring population (calculated by backdating the following years preseason survey) the following year.

4. It was assumed that the 29 percent mortality (including both hunting and winter mortality) could reasonably be translated into a hunting mortality rate of 18 percent (similar to the rate actually used in many years) of the preseason population followed by a winter mortality rate of 14 percent of the postseason population. The hunting mortality was assigned with 57 percent going to the male (trophy) cohort and 43 percent going to the female/fawn (non-trophy) cohort, which is similar to that used in many years.

5. It was assumed that adults, yearlings and fawns would make up 55 percent, 21 percent and 25 percent, respectively, of the non-trophy harvest (Treichel, Incisor Bar Age Reports, 1980-1982) and that yearling males would make up 22 percent of the trophy harvest (Treichel, Incisor Bar Age Reports, 1977-1982).

6. It was assumed that the summer antelope survey reflects an accurate age:sex composition of the population (Mean from 1963-1985 was 45 bucks:100 does:63 fawns). 
7. There are no data on actual winter mortality rates in Alberta but the assumed rate of 14 percent of the postseason population should be reasonable based on harvest rates and productivity information for known populations. Winter mortality rates for various age cohorts are unknown and were arbitrarily determined based on the following hierarchy of vulnerability. Fawns are most vulnerable because of their small size and inexperience; their assumed winter mortality rate was calculated to reduce their numbers to the predicted yearling population the following spring. Adult males are next in vulnerability because of their relatively poor condition going into winter following the rut. Yearlings would be next because of their inexperience, followed by adult does, which are the least vulnerable. Percentages chosen for yearlings and adults were those required to reduce their numbers to predicted populations the following spring.

8. The population model is intended to represent an average event in a stable population. It has been used to establish population and age/sex structure goals and average harvest goals in the management plan. It is recognized that actual events in any one year may be quite different than those predicted by the model. 
, 

